\title{
Reeling them in: Taxonomy of marine annelids used as bait by anglers in the Western Cape Province, South Africa
}

\author{
Carol Simon ${ }^{\text {Corresp., } 1}$, Jyothi Kara ${ }^{1,2}$, Alheit Du Toit ${ }^{1}$, Hendré van Rensburg ${ }^{1}$, Caveshlin Naidoo ${ }^{1}$, Conrad Matthee \\ ${ }^{1}$ Department of Botany and Zoology, University of Stellenbosch, Stellenbosch, Western Cape, South Africa \\ 2 Research and Exhibitions, Iziko Museums of South Africa, Cape Town, Western Cape, South Africa \\ Corresponding Author: Carol Simon \\ Email address: csimon@sun.ac.za
}

Background. Common names are frequently used inconsistently for marine annelid species used as bait in the peer-reviewed literature, field guides and legislative material. The taxonomy of many such species based on morphology only also ignores cryptic divergences not yet detected. Such inconsistencies hamper effective management of marine annelids, especially as fishing for recreation and subsistence is increasing. This study investigates the scale of the problem by studying the use and names of bait marine annelids in the Western Cape Province of South Africa. Methods. Fifteen recreational and six subsistence fishers at 12 popular fishing sites in the Western Cape Province donated 194 worms which they identified by common name. Worms were assigned scientific names according to a standard identification key for polychaetes from South Africa, and mitochondrial cytochrome oxidase I (COI) amplified and sequenced. Results. This study identified 11 nominal species known by 10 common names, in the families Siphonosomatidae, Arenicolidae, Sabellaridae, Lumbrineridae, Eunicidae, Onuphidae and Nereididae. Cryptic diversity was investigated through employing mitochondrial COI sequences and these data will facilitate future identifications among widely distributed species. Several species (Siphonosoma dayi, Abarenicola gilchristi, Scoletoma species, Marphysa corallina, Lysidice natalensis, Heptaceras quinquedens, Perinereis latipalpa) are reported as bait for the first time, and while the names blood- and moonshineworms were consistently applied to members of Arenicolidae and Onuphidae, respectively, coralworm was applied to members of Sabellaridae and Nereididae. Analysis of COI sequences supported morphological investigations that revealed the presence of two taxonomic units each for specimens initially identified as Gunnarea gaimardi and Scoletoma tetraura according to identification keys. Similarly, sequences for Scoletoma species and Lysidice natalensis generated in this study do not match those from specimens in China and India, respectively. Further research is required to resolve the species complexes detected and also to refine the use of names by fishermen over a wider geographic range. 
1 Reeling them in: Taxonomy of marine annelids used as bait by anglers in the Western Cape

2 Province, South Africa

3 Simon, C.A. ${ }^{* 1}$, Kara, J. ${ }^{1 \#}$, du Toit, A. ${ }^{1}$, van Rensburg, H. ${ }^{1}$, Naidoo, C. ${ }^{1}$, Matthee, C.A. ${ }^{1}$

4

$5 \quad{ }^{1}$ Department of Botany and Zoology, University of Stellenbosch, Stellenbosch, South Africa

6 \# Current Address: Research and Exhibitions Department, Iziko Museums of South Africa, Cape

7 Town, South Africa

8 *Corresponding Author: csimon@sun.ac.za

9 CAS: 0000-0001-9613-5222

10 CAM: 0000-0002-6836-069X

11 JK: 0000-0003-2961-1713

12 HVR: 0000-0001-7441-9929

13

14

15

16 
17 Abstract

18 Background. Common names are frequently used inconsistently for marine annelid species used as bait in the peer-reviewed literature, field guides and legislative material. The taxonomy of many such species based on morphology only also ignores cryptic divergences not yet detected. Such inconsistencies hamper effective management of marine annelids, especially as fishing for recreation and subsistence is increasing. This study investigates the scale of the problem by studying the use and names of bait marine annelids in the Western Cape Province of South Africa.

Methods. Fifteen recreational and six subsistence fishers at 12 popular fishing sites in the Western Cape Province donated 194 worms which they identified by common name. Worms were assigned scientific names according to a standard identification key for polychaetes from South Africa, and mitochondrial cytochrome oxidase I (COI) amplified and sequenced.

Results. This study identified 11 nominal species known by 10 common names, in the families Siphonosomatidae, Arenicolidae, Sabellaridae, Lumbrineridae, Eunicidae, Onuphidae and Nereididae. Cryptic diversity was investigated through employing mitochondrial COI sequences and these data will facilitate future identifications among widely distributed species. Several species (Siphonosoma dayi, Abarenicola gilchristi, Scoletoma species, Marphysa corallina, Lysidice natalensis, Heptaceras quinquedens, Perinereis latipalpa) are reported as bait for the first time, and while the names blood- and moonshineworms were consistently applied to members of Arenicolidae and Onuphidae, respectively, coralworm was applied to members of Sabellaridae and Nereididae. Analysis of COI sequences supported morphological investigations that revealed the presence of two taxonomic units each for specimens initially identified as Gunnarea gaimardi and Scoletoma tetraura according to identification keys. Similarly, sequences for Scoletoma species and Lysidice natalensis generated in this study do not match those from specimens in China and India, respectively. Further research is required to resolve the species complexes detected and also to refine the use of names by fishermen over a wider geographic range. 
45 Keywords: COI mtDNA, common name, pseudocryptic species, taxonomy, bloodworm, 46 coralworm, moonshineworm, musselworm, polychaetes, puddingworm, wonderworm 47 
49

50

51

52

53

54

55

56

57

\section{Introduction}

In South Africa, shore-based marine fishing is an important recreational activity and part of the livelihood for many subsistence fishermen and has shown a steady increase over the last decades (McGrath et al., 1997; Sowman et al., 2014; Saayman et al., 2017).There is a close link between shore fishing and bait collecting (MacKenzie, 2005), so an increase in fishing intensity will certainly correlate with an increase in harvesting of natural stocks of bait species (Nel \& Branch, 2014 cf. Hodgson, Allanson \& Cretchley, 2000; Napier, Turpie \& Clark, 2009; Simon et al., 2019a). However, in a recent assessment of the impacts of recreational and subsistence fishing in marine ecosystems in South Africa, impacts of bait collecting received just a passing mention (Majiedt et al., 2019). This supports Watson et al. (2017) who suggested that despite their wide use, marine annelids (i.e., polychaete worms) and probably many other bait species are universally a poorly managed resource.

A wide variety of marine invertebrates are used as bait by South African fishermen (MacKenzie 2005; Branch et al., 2016; DAFF, 2017). However, live marine annelids (indigenous or imported) are not sold in bait shops and are instead collected by subsistence and recreational fishermen who should possess appropriate permits (DAFF, 2017). Collection is controlled by taxon-specific daily limits (DAFF, 2017), but these restrictions have remained almost unchanged for decades (cf. Gaigher, 1979; van Herwerden et al., 1989 and DAFF, 2017). Furthermore, although nearly 2.5 million worms are harvested annually (Turpie, Heydenrych \& Lamberth, 2003), biological information to inform management strategies is limited (Gaigher, 1979; van Herwerden, 1989; Lewis, 2005; Simon et al. 2020) while restrictions on collection also do not accommodate the different bait collecting habits by recreational and subsistence fishermen (Simon et al. 2019a). Knowing which species are being utilised is an important step towards improving management of a resource as many bait species, including those that may be morphologically very similar, may have different life history traits and habitat requirements (Hutchings \& Lavesque, 2021), which may influence the vulnerability of species to exploitation. The Marine Recreational Activity Information Brochure issued by the Department of Agriculture, Forestry and Fisheries 
77 in South Africa (now the Department of Forestry, Fisheries and Environment; DAFF 2017) identifies bait worms generically as seaworms, polychaetes and flatworms, and by various common names. The only taxa identified by genus are Arenicola Lamarck, 1801, Nereis Linnaeus, 1758, Pseudonereis Kinberg, 1865b and Gunnarea Johannson, 1927. As no images are included in the brochure, it is unclear what the worms listed by common name are. However, the popular Two Oceans: A guide to the Marine Life of southern Africa (Branch et al., 2016) provides images and common and scientific names for some baitworms: bloodworm (Arenicola loveni Kinberg, 1866), musselworm (Pseudonereis podocirra (Schmarda, 1861) as P. variegata (Grube \& Kröyer, 1858)), wonderworm (Eunice aphroditois (Pallas, 1788)), Cape reef worm (Gunnarea gaimardi (Quatrefages, 1848), as G. capensis (Schmarda, 1861) in earlier editions), and the estuarine wonderworm (Marphysa haemasoma Quatrefages, 1866 as M. elityeni Lewis \& Karageorgopolous, 2008, see Kara et al. 2020). The species names for bloodworm, musselworm and Cape reef worm (also known as coralworm in Branch et al., 2016) correspond with those provided in the Government Gazette No. 39790 (Marine Living Resources Act 2014). The latter source, however, uses different names for E. aphroditois (Bobbit or errant worm), Arabella iricolor (Montagu, 1804) (moonshineworm) and M. haemasoma (wonderworms and listed as M. sanguinea (Montagu, 1813)). The situation is further complicated by reports of bait worms in other sources; for example, Diopatra Audouin \& Milne-Edwards, 1833 species have been called case worm (Day, 1974), moonshineworm (Napier, Turpie \& Clark, 2009; van Rensburg, Matthee \& Simon, 2020), estuarine wonderworm (Smith \& Smith, 2012; Allanson et al., 2016) and coralworm (Fielding, 2007, Fielding personal communication), while $E$. aphroditois has also been called coralworm (Wooldridge \& Coetzee, 1998). Thus, management of utilised worms may be hampered by confusion around the identities of the species that are harvested, and a lack of consensus in the names used among fishermen, scientists and managers active in South Africa.

The confusion around the use of common names is further complicated by recent taxonomic research which emphasised how poor our understanding of the biodiversity of South African marine annelids, including some used as bait, is. For example, $P$. podocirra and M. haemasoma 
106

107

108

109

110

111

112

113

114

115

116

117

118

119

120

121

122

123

124

125

126

127

128

129

130

131

132

133

134

were removed from synonymy with apparently globally widespread $P$. variegata and $M$.

sanguinea, respectively, so both are in fact indigenous to South Africa (Lewis \&

Karageorgopoulos, 2008; Kara, Macdonald \& Simon, 2018; 2020). By contrast, the Diopatra species used as bait in two estuaries on the south and southeast coasts of the country (van der Westhuizen \& Marais, 1977; Fielding, 2007; Napier, Turpie \& Clark, 2009; Simon et al., 2019a), was only recently identified as D. aciculata Knox \& Cameron, 1971 (van Rensburg, Matthee \& Simon, 2020). This species was originally described in Australia (Knox \& Cameron, 1971) and is probably alien in South Africa (Elgetany et al., 2020; van Rensburg, Matthee \& Simon, 2020). At least two other bait species, $A$. iricolor and E. aphroditois, are also apparently globally widespread with type localities geographically distant from South Africa (see Day, 1967), and may therefore either be misidentified indigenous, or unacknowledged alien species. Some species that are harvested (e.g., P. podocirra, E. aphroditois, A. iricolor, G. gaimardi) are also widespread within South Africa (Day, 1967; Branch et al., 2016). The ranges of these species, which have planktonic larvae, span multiple known phylogeographic barriers to gene flow in the region. It is thus likely that complexes of genetically distinct but morphologically identical or similar lineages exist (i.e., cryptic or pseudocryptic species, respectively), each with discrete distributions. This was shown for species previously identified as Pseudopolydora antennata Claparède, 1869 from temperate and subtropical regions of the country (Simon, Sato-Okoshi \& Abe, 2019b), emphasising the need for thorough taxonomic studies of seemingly widespread species.

This study builds on taxonomic information gathered to date, and explores the use of common names and the nomenclature of marine annelid worms used as bait in the Western Cape Province where fishing is particularly popular (Madjiet et al., 2019), and where harvesting of worms is high (Turpie, Heydenrych \& Lamberth, 2003). Furthermore, the province spans two vicariant barriers to gene flow at Cape Point and Cape Agulhas (Teske et al., 2011, Fig. 1), and this may also split species into different taxonomic units. The specific aims of the study are to: 1) identify and provide updated descriptions of the annelid species collected as bait by recreational and subsistence fishermen in the Western Cape Province of South Africa; 2) collate 
135 the common names used by the fishermen towards developing consensus for improved

136 management; and 3) generate mtCOI sequences to explore the existence of species complexes

137 locally and globally and facilitate identifications.

138

\section{Methodology}

Sample sites and collection

Sampling was conducted at 12 popular beach and estuarine fishing locations in the Western Cape Province, South Africa (Fig. 1), from June 2016 to May 2017. Collectively, these sites included sandy (Saldanha Bay, Muizenberg, Strand, Betty’s Bay, Pearly Beach, Struisbaai, Witsand, Knysna) and or rocky (Velddrif, Melkbosstrand, Kommetjie, Betty's Bay, Hermanus, Witsand) habitats, which would influence the presence and absence of species collected. Most worms were donated by bait collectors who all gave their prior consent to participate in the project. Involvement by most recreational fishermen was confirmed prior to sampling via fishing mailing lists or word of mouth. Some additional recreational and all subsistence fishermen were approached on site. After the aims of the study were described to participants and verbal consent received (ethical clearance number: SU-HSD-001609 from Stellenbosch University), worms were collected according to the permitted methods (DAFF 2017), under permit RES2017-27 issued to CAS by the Department of Forestry, Fisheries and Environment. Additional samples of arenicolids (bloodworm) were collected by the authors using the same techniques (see Simon et al., 2020). The common names used by the bait collectors were noted for all worms. All sampling was conducted during low tide, with specific collection methods for the different taxa included in the systematic accounts below. In some instances, fishermen were only willing to donate a small piece of the worm that was sufficient for genetic analysis.

Specimen identification and processing

160 Samples were relaxed in an isotonic solution of $7 \% \mathrm{MgCl}_{2}$ in tap water, measured and photographed. A section of each specimen from the mid-body or posterior was placed in $96 \%$ ethanol for molecular analysis. The rest of the specimen was fixed in $4 \%$ formalin in seawater for at least 2 days, washed in distilled water and stored in 70\% ethanol. Samples were 
164

165

166

167

168

169

170

171

172

173

174

175

176

177

178

179

180

181

182

183

184

185

186

187

188

189

190

191

192

examined on Leica DM1000 light and MZ75 dissecting microscopes, and photographed with a Leica EC3 camera attachment, or on Leica DM750 light and M80 dissecting microscopes and photographed with an Olympus Targus TG5 attached to the microscope eyepieces. Where necessary, images were stacked in Helicon Focus Version 7.6.4 and processed in Photoshop Version C6. Specimens were identified using Day (1967; 1974), and where necessary, more recent literature appropriate to individual taxa. All specimens were deposited at IZIKO South African Museum (Table 1).

\section{DNA extraction, amplification and sequencing}

Approximately $25 \mathrm{mg}$ of tissue was used either from mid-section or posterior end to extract DNA using the Zymo Quick DNA ${ }^{\mathrm{TM}}$ MiniPrep Plus kit (Zymo-Spin ${ }^{\mathrm{TM}}$ ) according to manufacturer's protocol. The universal primer pair: LCO1490 and HCO2198 (Folmer et al., 1994) was used to amplify a fragment of the cytochrome oxidase subunit 1 gene for all species. The following PCR thermal conditions were used: $94^{\circ} \mathrm{C}$ for 3 minutes; 34 cycles with $94^{\circ} \mathrm{C}$ for 45 seconds, $42^{\circ} \mathrm{C}$ for 1 minute and $72^{\circ} \mathrm{C}$ for 1 minute and a final extension at $72^{\circ} \mathrm{C}$ for 7 minutes (Bleidorn et al., 2005). The amplified PCR products were visualised on a 1\% agarose gel using $3 \mu$ of PCR product and $5 \mu$ l of Quick-Load Purple 100bp DNA ladder (New England BioLabs Inc.), following Simon et al. (2020). All PCR products were sequenced using Sanger sequencing at the Central Analytical Facility at Stellenbosch University. All newly generated sequences were uploaded on GenBank (Table 1).

\section{$\underline{\text { Molecular analysis }}$}

Sequences were edited in BioEdit Version 7.2.6 (Hall, 1999) and aligned using ClustalW with default parameters in MEGA X (Kumar et al., 2018). Neighbour joining trees were constructed in the same program, per family. Nodal support was obtained using 10000 bootstrap replicates using the maximum composite likelihood method, with uniform rates and pairwise deletion.

\section{Results}


193 Worms were donated by 15 recreational and six subsistence fishers, with two additional fishers

194 who were not categorised (Table 1). In total, these fishers donated 194 specimens belonging to 195 seven families and 11 nominal species: Siphonosoma dayi Stephen, 1942, Abarenicola gilchristi 196 Wells, 1963, Arenicola loveni, Gunnarea gaimardi, Scoletoma cf. tetraura, Marphysa cf. 197 corallina, M. haemasoma, Lysidice natalensis Kinberg, 1865, Heptaceras quinquedens (Day, 198 1951), Perinereis latipalpa (Schmarda, 1861) and Pseudonereis podocirra (Table 1). Together, 199 these species were referred to by 10 common names (Table 1). Sequences could not be 200 generated for Heptaceras quinquedens and Perinereis latipala even after multiple attempts, with the remaining nine species representing 11 genetically distinct species, including two species each of Gunnarea and Scoletoma (Table 1).

$\underline{\text { Taxonomic account }}$

Order: Sipuncula Stephen, 1964

206

Family: Siphonosomatidae Kawauchi, Sharma \& Giribet, 2012

207

Genus: Siphonosoma Spengel, 1912

208

Species: Siphonosoma dayi Stephen, 1942

209

Figs $2 \& 3$

210

211

Siphonosoma dayi Stephen, 1942: 246 - 247, PI. XI, Figs 1 \& 2; Day 1974: 49

212

Common name: Sandworm.

213

Material examined: Knysna: $34^{\circ} 03^{\prime} 56.0^{\prime \prime} \mathrm{S} 23^{\circ} 02^{\prime} 57.4^{\prime \prime E}, 2$ specimens, MB-A090313 and MB-

A090318, 27 January 2017, coll. A. N. du Toit, mid-intertidal sandflats in estuary.

Description: Trunk length 198 and $230 \mathrm{~mm}$, introvert of former $17 \mathrm{~mm}$. In life body light to dark pink, colour retained after fixation (Fig. 2A), internally pearlescent pink (Fig. 2E - H). Skin covered with oval shaped papillae in longitudinal rows, following contours of circular muscle, appear white after fixation. Introvert has terminal mouth ringed with short tentacles (Fig. 2B); papillae chitinised, tubular, scale-like and with dark edges arranged in rows on circular muscle 
222 bands (Fig. 2B - D); larger and more numerous in anterior end (Fig. 2C) than posterior (Fig. 2D).

223 Longitudinal muscle-layer divided into 21 or 22 bands (Fig. 2E, G, black arrows), anastomosing

224 anteriorly to form single sheet in region of introvert (Fig. 2E, black arrowhead). Four retractor

225 muscles; dorsal pair attached to body wall anteriorly, ventral pair attached more posteriorly

226 (Fig. 2E, G, H white arrowheads). Two branches of spindle muscle insert close to dorsal

227 retractor muscles (Fig. 2H, black arrowhead). One pair of nephridia (Fig. 2E, F).

228

229

Remarks: New specimens match the original description by Stephen (1942). Although only two

specimens were collected and sequenced, S. dayi (Fig. 3) forms a well-supported clade which is

independent from other known species within the genus.

232

233

Collection method: Hand digging and pumping.

234 Type locality: Knysna, Western Cape Province, South Africa.

235

Known distribution in South Africa: Knysna (Day, 1974).

236 Ecology: In sand in low to mid intertidal in estuary.

237

238

Subclass: Sedentaria Lamarck, 1818

239

Infraclass: Scolecida Rouse \& Fauchald, 1997

240

Family: Arenicolidae Johnston, 1835

241

Genus: Arenicola Lamarck, 1801

242

Species: Arenicola loveni Kinberg, 1866

243

Figs $4-6 A \& B$

244

Arenicola loveni Kinberg, 1866: 355; Ashworth 1911: 2 - 17, Figs 1 - 3; Wells 1962: 348, PI. 2 \&

4; Day 1967: 610, Fig. 29.1 f-k; Day 1974: 62, Fig. 54; Branch et al. 2016: 72, Fig. 27.9

Common name: Bloodworm.

248

Material examined: Betty's Bay: 34²2'39.6"S 1851'21.6"E, 3 specimens, MB-A090220 - MB- 
$25123^{\circ} 02^{\prime} 30.9^{\prime \prime E}, 3$ specimens, MB-A090231 - MB-A090233, 27 January 2017, 3403'54.3"S

252 2303'03.7"E, 2 specimens MB-A090234 - MB-A090235, 28 January 2017, 2 specimens,

253 3403'54.3"S 2303'03.7"E, 29 January 2017, MB-A090236 - MB-A090237, mid-intertidal sandy

254 beach, coll. A. du Toit. Muizenberg, 3406'18.7"S 18²8'47.4"E, 1 specimen, MB-A090230, 13

255 March 2017, coll. A. du Toit, 3406'27.6"S 18²8'22.3"E, 1 specimen, MB-A090227, 2 specimens, $25634^{\circ} 06^{\prime} 18.7^{\prime \prime S} 18^{\circ} 28^{\prime} 47.4^{\prime \prime E}, \mathrm{MB}-\mathrm{A} 090228$ - MB-A090229, 25 February 2017, 3406'27.6"S

257 18²8'22.3"E, 1 specimen, MB-A090374, 25 February 2017, coll. A. du Toit and C. Naidoo; low

258 intertidal in surf zone, sandy beach. Pearly Beach: 34³9'33"S 19²9'27.43.6"E, 3 specimens

259 MB-A090246 - MB-A090248, 12 February 2017, coll. A. du Toit and H. van Rensburg, low-

260 intertidal, sandy beach. Saldanha Bay: $33^{\circ} 00^{\prime} 26.9^{\prime \prime S} 17^{\circ} 56^{\prime} 46.3^{\prime \prime E}, 7$ specimens, MB-A090257 -

261 MB-A090263, 27 May 2017; 3259'49.3"S 1757'58.3"E, 3 specimens, MB-A090264 - MB-

262 A090266, 27 May 2017, 3300'26.9"S 1756'46.3"E, 1 specimen, MB-A090375, 27 May 2017,

263 coll. C. Naidoo, low intertidal, sandy beach. Struisbaai: 34²7'41.1"S 2002'57.6"E, 1 specimen,

264 MB-A090238, 12 February 2017; 3 specimens, MB-A090239 - MB-A090241, 10 April 2017, 4

265 specimens, MB-A090242 - MB-A090245, coll. C. Naidoo, A. du Toit and H. van Rensburg, mid to

266 low intertidal, sandy beach. Witsand: $34^{\circ} 23^{\prime} 59.9^{\prime \prime S} 20^{\circ} 49^{\prime} 47.5^{\prime \prime E}, 7$ specimens, MB-A090250 -

267 MB-A090256, coll. C. Naidoo, low intertidal, sandy beach.

268

269

Description: Live specimens up to $580 \mathrm{~mm}$, including tail. Fixed specimens up to $296 \mathrm{~mm}$ long

270

(excluding achaetous tail), $19.2 \mathrm{~mm}$ wide at chaetiger 1 . In life, body colour variable; pink to brown, dark brown to black; usually darker in anterior, becoming lighter from branchial region

272 posteriorly (Fig. 4A, B, D), colour retained when fixed. Epidermis tessellated to chaetiger 5 or 6 , papillated from chaetae 6 or 7 onward, including achaetous tail. Chaetigerous annuli prominent, number of annuli between first 4 chaetigers 2-3-4, thereafter 4 (Fig. 4D). Anterior region consists of trilobed, non-retractable prostomium with nuchal groove on each side (Fig. 4E, arrows). One achaetous segment with 2 annuli (Fig. 4C). Proboscis eversible; covered with papillae, no pigment (Fig. 4C, E-H). Papillae on proximal section large and triangular (Fig. 4C, E, F, H). Papillae in median section more densely packed, small and nippleshaped, becoming larger and more conical distally (Fig. 4C, F, G). One pair of long septal 
280

281

282

283

284

285

286

287

288

289

290

291

292

293

294

295

296

297

298

299

300

301

302

303

304

305

306

307

pouches that reach back to at least third diaphragm (Fig. 5A, B). One pair of conical oesophageal caecae (Fig. 5A). Thorax with 19 chaetigers. Notopodia rounded triangles, retractable lobes in oval torus (Fig. 5E). Notochaetae capillaries in two rows, anterior row shorter than posterior; with lateral toothed-crests and spinulose lamina (Fig. 6A). Neuropodia oval bearing single row of unidentate hooks (Fig. 6B), sometimes with faint denticle.

Neuropodia long, approach midline of venter in branchiate region. Branchiae on chaetigers 7 19 (13 pairs), highly vascularised, highly branched, arborescent (tree-shaped) (Fig. 5F). On chaetiger 7 branchiae vestigial; 2 - 10 short gill stems, palmar membrane sometimes inconspicuous (Fig. 5E). Up to 22 main gill stems on branchiae on chaetigers 8 to 18, usually fewer on chaetiger 19. Palmar membrane fuse lower third of gill stems (Fig. 5F), sometimes papillated (Fig. 5G). Five pairs of nephridia on chaetigers 5-9; nephridiopores hooded, partially hooded (Fig. 5C, D) or unhooded, posterior to dorsal end of neuropodium. Tail achaetous, papillated, anus terminal.

Remarks: Specimens examined here conform to descriptions by Ashworth (1911) and Wells (1962) which included type material, but maximum size is larger. However, oval depressions seen by Ashworth (1911) ventral to some notopodia were not observed. The colour variants of A. loveni from all sites form a well-supported clade (Fig. 7) which is exemplified by the fact that those illustrated in Fig. 4A, B and D are represented by an identical sequence (MK 922158). This clade includes two subclades, representing specimens collected on the west and south coasts, respectively. The structure seen here was previously reported in Simon et al. (2020), where nuclear data confirmed that these west and south coast clades represent a single species. The separation between these clades is demarcated by Cape Point, a location known to present a barrier to gene flow (Teske et al. 2011; Simon et al. 2020).

\section{Type locality: Durban, KwaZulu-Natal, South Africa.}

Collection method: By pump or digging with hand or trowel and hooking out with a wire. In Muizenburg collected from within surfzone. 
308

309

310

311

312

313

314

315

316

317

318

319

320

321

322

323

324

325

326

327

328

329

330

331

332

333

334

335

Known distribution in South Africa: Saldanha Bay (Western Cape Province) to Durban (Kwa-Zulu Natal) (Day 1967).

Ecology: In sand in low to mid intertidal on sheltered sandy shores and estuaries.

Genus: Abarenicola Wells, 1959

Species: Abarenicola gilchristi Wells, 1963

Figs $6 C \& D \& 8$

Abarenicola gilchristi Wells, 1963: 147 - 149, Fig. 6c, PI. 2 \& 5; Day 1967: 611 - 612, Fig. 29.2

Arenicola assimilis var. affinis Ashworth 1911: 18, Figs 4 \& 5 (in part); Day 1955: 427

Common name: Bloodworm, bakkiewurm.

Material examined: Betty's Bay: $34^{\circ} 22^{\prime} \mathrm{S} 18^{\circ} 51^{\prime} \mathrm{E}, 4$ specimens (incomplete) (MB-A090223 - MBA090226), 3 June 2016, mid-intertidal, sand, coll. E. Newman. Pearly Beach: 34³9'48.4"S 19²9'17.2"E, 1 specimen (MB-A090249), 10 April 2017, low-intertidal, sand, coll. A. du Toit and C. Naidoo.

Description: Up to $89 \mathrm{~mm}$ long (excluding achaetous tail), $11 \mathrm{~mm}$ wide at chaetiger 1 . In life, body orange-pink (Fig. 8A), light to dark pink when fixed (Fig. 8B). Epidermis tessellated to chaetiger 4 or middle of chaetiger 5, papillated thereafter. Chaetigerous annuli of first three chaetigers prominent, number of annuli between first four chaetigers 2-2 (3 in one specimen)4, thereafter 4 (Fig. 8B). Anterior region consists of trilobed, non-retractable prostomium and one achaetous segment (Fig. 8B, D). Nuchal groove on each side (Fig. 8D). Proboscis eversible; covered in papillae, no pigment (Fig. 8C). Papillae on proximal section sparsely distributed, prominent, irregular in size, rounded (Fig. 8H). Papillae in median section densely packed, small, rounded, skin folded (Fig. 8G). Papillae of distal section densely packed, conical (Fig. 8F).

Oesophageal caecae with one elongate and 11 to 20 smaller caecae on either side of mid-line (Fig. 8E), elongate double to more than triple length of short caecae. 
336 Thorax with 19 chaetigers. Notopodia rounded triangles, retractable lobes in oval torus.

337 Notochaetae spinulose capillaries (Fig. 6C) in single row. Neuropodia oval bearing single row of

338 unidentate, finely serrated, hooks (Fig. 6D). Neuropodia short, do not approach midline of

339 venter. Branchiae on chaetigers 8-19 (12 pairs) (Fig. 8A). Branchiae highly vascularised, large,

340 up to 19 main gill stems; highly branched, arborescent (tree-shaped), with lateral branches and

341 gill filaments off each stem (Fig. 8I). Palmar membrane fuse lower third to half of gill stems (Fig.

342 8I). Five pairs of nephridia on chaetigers 5 - 9; nephridiopores unhooded, hooded, and partially

343 hooded (Fig. 8J - L), posterior to dorsal end of neuropodium. Tail achaetous, papillate, anus

344 terminal.

345

346

Remarks: Specimens examined here conform to description by Wells (1963) and Day (1967), but are smaller. Abarenicola gilchristi formed part of a distinct lineage in a well-supported clade

(Fig. 7) also comprising Abarenicola brevior (Wells, 1963) and A. wellsi Darbyshire, 2017.

Collection method: By hand or digging with trowel.

Type locality: Buffelsbaai, Cape Peninsula, Eastern Cape province, South Africa.

352

353

354

355

356

357

358

359

360

361

362

363

Known distribution in South Africa: Lambert's Bay to Walker Bay. Presence in Pearly Beach.

extends known distribution (Day, 1967) eastwards by only a few kilometres. Namibia: Luderitz.

Report in Tamil Nadu, India (Thilagavathi et al., 2013) must be treated with caution.

Ecology: In sand in mid to low intertidal on sheltered shores.

Order: Sabellida Levinsen, 1883

Family: Sabellariidae Johnston, 1865

Genus: Gunnarea Johannson, 1927

Species: Gunnarea gaimardi (Quatrefages, 1848)

Fig. 9

?Pallasia gaimardi Quatrefages, 1848a: 24, 1866: 322, PI. 13. Figs $17 \& 18$ 
364 ?Hermella capensis Schmarda, 1861: 23, PI. 23. Fig. 171. ?Sabellaria capensis McIntosh 1885:

365 418, PI. 25A Figs 24 \& 25, PI. 26A Figs 11712

366 Gunnarea capensis Day 1967: Fig. 33.2.d-i (NOT Schmarda, 1861), in partum

367 Gunnarea gaimardi Kirtley 1994: Fig. 3.1.2.a - e, in partum

368 Gunnarea gaimardi Branch et al. 2016: 73, Fig. 28.3

369 Common name: Coralworm, Cape reef worm, polwurm.

370

371

Material examined: Velddrif: $32^{\circ} 46^{\prime} 08.8^{\prime \prime} \mathrm{S} 18^{\circ} 08^{\prime} 44.2^{\prime \prime} \mathrm{E}, 10$ specimens (incomplete), MBA090356 - MB-A090358, MB-A090360, MB-A090364, MB-A090367 - MB-A090371, 26 May 2017, sand reefs in the mid-intertidal rock pools, coll. A. N. du Toit. Bettys Bay: 34²2'39.6"S 1851'21.6"E, 5 specimens (incomplete), MB-A090336, MB-A090337, MB-A090339 - MBA090441), 3 June 2016, reefs in the lower intertidal zone, coll. E. Newman. Hermanus: 34²4'41.1"S 19¹6'44.8"E, 8 specimens (incomplete), MB-A090341 - MB-A090348), 11 February 2017, low to mid intertidal, coll. A. N. du Toit and H. van Rensburg.

Description: Body a maximum of $110 \mathrm{~mm}$ in length; body colour opaque white and cream with irregular dark brown spots when fixed (Fig. 9A - C). Opercular crown and opercular stalk completely fused (Fig. 9B). Two rows of golden outer and inner paleae, arranged in two concentric rows (Fig. 9B). Approximately $44-48$ outer paleae and $35-46$ inner paleae. Outer paleae geniculate, obtuse in shape with a single weak tooth on the antero-lateral margin (Fig. 9D1, 3). Inner paleae geniculate with elongate, wedge-shaped peaks with sharp tips (Fig. 9D2), arranged toward the midline of the crown with no overlap in paleae (Fig. 9B-C). Anterior margin of crown with $49-73$ conical papillae (Fig. 9B). Pair of ciliated palps in front of the mouth (Fig. 9E). Buccal lips present, with upper, lower and lateral lips (Fig. 9E). Tentacular filaments compound and branched (Fig. 9C). U-shaped building organ on the thorax (Fig. 9E); neurochaetae consists of capillaries with bipinnate blade margins (Fig. 9F); Parathorax consist of three chaetigers; notochaetae lanceolate interspersed with capillaries (Fig. 9H); neurochaetae alternating lanceolate chaetae of two lengths (Fig. 9G); neurochaetae thinner than notochaetae. Abdomen with pairs of branchiae on each segment; neuropodial lobes 
393

394

395 396

397

398

399

400

401

402

403

404

405

406

407

408

409

410

411

412

413

414

415

416

417

418

419

420

421

reduced on abdominal chaetigers, surrounded by tori; uncini with five teeth (Fig. 9J);

neurochaetae verticillate chaetae (Fig. 9l); ventral cirri conical with tapering ends, becoming digitiform with rounded ends, spanning the neuropodial lobe.

Remarks: Specimens collected from all western sites (Veldrif, Betty's Bay and Hermanus) conformed to the general descriptions according to Day (1967) and Kirtley (1994). Nonetheless, differences in the morphology of the outer paleae were observed. Day (1967) described two incurving teeth present on the outer paleae, but this differs from what was observed in specimens collected in the present study: one tooth on the antero-lateral margin of the outer paleae. Additionally, Day (1967), described the inner paleae as completely concealing the "fleshy disk" or opercular disk, however, this was not observed for our specimens, instead the opercular disk was visible in the mid-section where paleae did not overlap, which was similar to Kirtley (1994). Nonetheless, all other characters observed for our specimens were similar to specimens as described by Kirtley (1994) and Day (1967), suggesting that they most likely represent Gunnarea gaimardi sensu stricto. Molecular analyses (Fig. 10) will be discussed under Gunnarea sp. 1.

Collection method: Breaking off pieces of reef by hand or narrow blade to remove worms from tubes.

Type locality: Cape of Good Hope, Western Cape Province, South Africa.

Known distribution in South Africa: the nominal species has been reported from KwaZulu-Natal on the east coast to the west coast of the Western Cape Province; Namibia: Walvis Bay to Luderitz (Day, 1967), but this needs to be revised.

Ecology: Species form extensive reefs by building sandy tubes on rocks in the low to mid intertidal of exposed shores.

Species: Gunnarea sp. 1

Fig. 11 
422 Material examined: Witsand: $34^{\circ} 23^{\prime} 31.9^{\prime \prime} \mathrm{S} 20^{\circ} 51^{\prime} 50.1^{\prime \prime} \mathrm{E}, 2$ specimens (incomplete), MB-

423 A090293, MB-A090294, 30 April 2017, low to mid intertidal, coll. A. N. du Toit.

424

425

Description: Body maximum of 43 mm (MB-A090293) in length (MB-A090294 = 34 mm), when

fixed body colour opaque white with black pigmentation throughout (Fig. 11A, B). Opercular

427 crown and opercular stalk completely fused (Fig. 11B). Two rows of golden inner and outer paleae (Fig. 11B). Approximately $34-38$ inner paleae and $42-43$ outer paleae. Outer paleae geniculate with a single tooth on the antero-dorsal margin (Fig. 11G2, 3), inner paleae geniculate with elongate, wedge-shaped peaks with a sharp tip (Fig. 11G1), and orientated toward the midline, with both rows overlapping and concealing the opercular disk (Fig. 11B). Anterior margin of opercular crown with 50 conical papillae (Fig. 11B). Pair of ciliated palps in front of mouth (Fig. 11E). Buccal lips present with upper, lower and lateral lips (Fig. 11E). Tentacular filaments compound and branched (Fig. 11E). U-shaped building organ as part of thorax (Fig. 11E); neurochaetae capillaries with bipinnate blade margins (Fig. 11C). Parathorax of three chaetigers; notochaetae alternating lanceolate and capillary chaetae (Fig. $11 \mathrm{H}$ ), neurochaetae lanceolate chaetae of two lengths (Fig. 11I), neurochaetae thinner than notochaetae. Abdomen with a pair of branchiae on each segment; reduced neuropodial lobes surrounded by tori, uncini with seven teeth (Fig. 11F); neurochaetae verticillate (Fig. 11D). Ventral cirri conical with tapering ends, becoming digitiform with rounded ends spanning the neuriopodial lobes.

Remarks: Specimens collected from Witsand (southern site) conformed to the general description by Day (1967), including having paleae that completely conceal the "fleshy disk" or opercular disk. Specimens from the southern site generally resemble Gunnarea gaimardi (from western sites) in having a single tooth on the antero-lateral margin of the outer paleae. Nonetheless several differences were observed. Firstly, western site specimens were longer (max. of $110 \mathrm{~mm}$ ), whereas southern specimens were a maximum of $43 \mathrm{~mm}$. The most distinct feature between these two morpho-groups was the shape, orientation and arrangement of 450 paleae on the opercular crown. The peaks of the outer and inner paleae are longer in 
451 specimens from the southern site compared to that observed in specimens from the western

452 sites; the angle of inclination between the handle and peaks of the inner paleae is larger in

453 western specimens than southern specimens; the outer paleae blades are wider and shorter in

454 specimens from southern sites compared to the longer, thinner blades observed in western

455 specimens. The inner paleae in western specimens do not overlap at the midpoint of the 456 opercular disk, thereby exposing the disk, whereas in southern specimens the paleae overlap,

457 completely concealing the disk. Additionally, the abdominal uncini of western specimens have

458 five teeth, which is two less than that observed for southern specimens. Lastly, western

459 specimens have more opercular papillae than southern specimens when comparing similar

460 sized animals; 73, length $45 \mathrm{~mm}$ and 50 , length $43 \mathrm{~mm}$, respectively. These differences noted

461 between specimens collected from the southern site and G. gaimardi from western sites

462 indicate that they are indeed separate species and that specimens from the southern site

463 (Witsand) most likely represents a new undescribed species of the genus. These morphological

464 differences are supported by the molecular analysis which recovered two well supported clades

465 (Fig. 10) and a genetic distance of $6 \%( \pm 0.02)$, thus confirming their separation as independent

466 species. The first clade, designated G. gaimardi, included specimens from Velddrif, Betty's Bay

467 and Hermanus (western group) and the second, designated Gunnarea sp. 1, included only the

468 specimens from Witsand (Fig. 10). Morphological differences together with the genetic

469 separation of the clades indicate the presence of two species in what has, till now, been

470 considered a monospecific genus (Capa, Hutchings \& Peart 2012). Preliminary observations of

471 Gunnarea sp. from Port Shepstone in KwaZulu-Natal suggest that they conform to the

472 description of Gunnarea sp. 1 and studies are underway to confirm this.

473

474 Collection method: Breaking off pieces of reef by hand or narrow blade to remove worms from 475 tubes.

476 Known distribution in South Africa: Witsand, Western Cape Province, South Africa.

477 Ecology: Species form extensive reefs by building sandy tubes on rocks in the low to mid 478 intertidal of exposed shores.

479 
480

481

482

483

484

485

486

487

488

489

490

491

492

493

494

495

496

497

498

499

500

501

502

503

504

505

506

507

Order: Eunicida Dales, 1962

Family: Lumbrineridae Schmarda, 1861

Genus: Scoletoma Blainville, 1828

Species: Scoletoma sp. 1

Fig. 12

?Lumbrinereis tetraurus Day 1953: 435

?Lumbrineris tetraura Day 1967: 437, 439, Fig. 17.16 U - W, Branch et al. 2016: 70, Fig. 26.10

Common name: Puddingworm.

Material examined: Betty's Bay: 34²2'S 1851'E, 1 specimen (incomplete), MB-A090332, 3 June 2016, sandy sediment, coll. E. Newman.

Description: more than $145 \mathrm{~mm} ; \mathrm{L} 10=8.1 \mathrm{~mm}, \mathrm{~W} 10=3.4 \mathrm{~mm}$ (Fig. 12A). Prostomium conical, peristomium with two rings, second slightly shorter than first (Fig. 12A). No eyes. Prechaetal lobes truncate throughout, postchaetal lobe longer and bluntly triangular, becoming longer towards posterior end (Fig. 12C - E). Winged capillary chaetae from chaetiger 1 to approximately chaetiger 57 . Long-headed simple multidentate hooded hooks (about $0.2 \mathrm{~mm}$ long) from approximately chaetiger 4, shortening posteriorly (Fig. 12F, G), after about chaetiger 35, head becomes even shorter with flared hood (Fig. 12H), appearing white. Aciculae yellow. Dental formula: $\mathrm{MI}=1+1, \mathrm{MII}=5+5, \mathrm{MIII}=2+2, \mathrm{MIV}=1+1$ (Fig. 12B), MV free, lateral to MIV and MIII.

Remarks: The specimen conforms to the general description of S. tetraura according to Schmarda (1861) and Day (1967), and no characters could be identified to distinguish the specimen collected here from the description of specimens from Chile. However, the specimen differs morphologically and genetically from others collected in this study that also conform to the description of S. tetraura by Day (1967), and genetically from specimens identified as $S$. 
508 tetraura in China (Fig. 13; discussed under Scoletoma sp. 2 below). The species is therefore

509 identified here as Scoletoma sp. 1.

510

511 Collection method: Collected with a small trowel from sediment.

512 Apparent distribution in South Africa: Known only from a single site. It closely resembles

513 Scoletoma tetraura which has been reported from Namibia to KwaZulu-Natal.

514 Ecology: Burrows into sand in rock pools.

515

516 Species: Scoletoma sp. 2

517 Fig. 14

518

519 ?Lumbrinereis tetraurus Day 1953: 435

520 ?Lumbrineris tetraura Day 1967: 437, 439, Fig. 17.16 u - w, Branch et al. 2016: 70, Fig. 26.10

521 Common name: Puddingworm.

522

523

Material examined: Hermanus, Kammabaai: 34²4'41.1"S 19²16'44.8"E, 6 specimens

524 (incomplete), MB-A090349 - MB-A090354, 11 February 2017, from rock pools in low to mid 525 intertidal, coll. A. N. du Toit and H van Rensburg.

526

527

Description: up to more than $300 \mathrm{~mm}$; L10 $=6.8$ to $9.8 \mathrm{~mm}, \mathrm{~W} 10=1.9$ to $3.4 \mathrm{~mm}$. Prostomium 528 conical, peristomium with two rings, second slightly shorter than first (Fig. 14A). No eyes. Prechaetal lobes truncate, short and rounded throughout, postchaetal lobe longer and bluntly triangular in anterior chaetigers, becoming digitiform and longer towards posterior end (Fig. 14C - E). Winged capillary chaetae from chaetiger 1 to approximately chaetiger 56 to 70 . Longheaded simple multidentate hooded hooks (about $0.15 \mathrm{~mm}$ long) from approximately chaetiger

533 4, shortening posteriorly (Fig. 14F, G), after about chaetiger 25, but usually after about 534 chaetiger 30 to 35, head becomes even shorter with flared hood (Fig. 14H), appearing white 535 (Fig. 14E). Aciculae yellow. Dental formula (variation): $\mathrm{MI}=1+1, \mathrm{MII}=5(6)+5, \mathrm{MIII}=2(1)+1$ 536 (2), MIV = $1+1$ (Fig. 14B), MV free, lateral to MIV and MIII. 
Remarks: All six specimens conform to the general description of S. tetraura according to Schmarda (1861) and Day (1967), and no characters could be identified to distinguish the specimens collected here from the description of specimens from Chile. However, this species differs from the specimen from Betty's Bay. In Scoletoma sp. 2 from Hermanus, the longheaded simple hooded hooks are about 25\% shorter than those of Scoletoma sp. 1 from Betty's Bay, and post-chaetal lobes are about 30\% longer in the posterior. Furthermore, the segments of Scoletoma sp. 2 appear to be longer than those of Scoletoma sp. 1; in specimens that are similarly wide, specimens of the former are 1.5 to $1.8 \mathrm{~mm}$ longer for the first 10 chaetigers than in the latter. Finally, specimens of the two species were collected from different habitats. Further research is needed to determine which, if any, refers to the species recorded previously by Day (1967) as S. tetraura.

The morphological separation is supported by molecular analyses (Fig. 13) that retrieved two well-supported operational taxonomic units, Scoletoma sp. 1 (from Betty's Bay) and Scoletoma sp. 2 (from Hermanus). The two Scoletoma species from South Africa form part of a weakly supported clade together with Scoletoma fragilis (O.F. Müller, 1776), Lumbrineris aberrans Day, 1963, Lumbrineris erecta Moore, 1904, Lumbrineris japonica Marenzeller, 1879, and Lumbrineris perkinsi Carrera-Parra, 2001 which is separate from S. tetraura from China. The separation of Scoletoma spp 1 and 2 from South Africa and S. tetraura from China in two different clades with high support suggests that they are independent species. However, without sequences from the species' type locality in Chile, it is impossible to determine whether the specimens found in China and South Africa all represent new species or whether one of them is an alien. Specimens from the extended global distribution of S. tetraura need to be examined, as there are likely more species within this complex. Additionally, S. tetraura and whether this genus is paraphyletic. 
566 Collection method: Samples from Hermanus collected among broken pieces of Gunnarea tubes.

567 Apparent distribution in South Africa: Known only from a single site. It closely resembles

568 Scoletoma tetraura, which has been reported from Namibia to KwaZulu-Natal.

569 Ecology: Burrows into sand among Gunnarea tubes.

570

571 Family: Eunicidae Berthold, 1827

572 Genus: Marphysa Quatrefages, 1866

573 Species: Marphysa cf. corallina

574 Fig. 15

575

576 Marphysa corallina Day 1967: 400, Fig. 17.7 F - J; Branch et al. 2016: 70, Fig 26.7

577 Common name: Wonderworm.

578

579

Material examined: Witsand: $34^{\circ} 23^{\prime} 31.9^{\prime \prime S} 20^{\circ} 51^{\prime} 50.1^{\prime \prime E}, 5$ specimens, (incomplete) MB-

580 A090276 - MB-A090280, 30 April 2017, under rocks in rock pools in mid-intertidal, coll. A. N. du 581 Toit.

582

583

Description: Body length more than $120 \mathrm{~mm} ; \mathrm{L} 10=8-11 \mathrm{~mm}, \mathrm{~W} 10=0.4-0.5 \mathrm{~mm}$. In live

584 specimens, body colour medium to dark brown in anterior becoming light brown in posterior;

585 iridescent throughout (Fig. 15A). Prostomium bilobed, lobes frontally rounded; sulcus deep.

586 Prostomial appendages semi-circular with white tapering tips (Fig. 15A); pair of palps extend to

587 second peristomial ring; pair of lateral antennae reaching second segment and one median

588 antenna extending to third segment (Fig. 15A). Black reniform eye spots below pair of lateral

589 antennae (Fig. 15A, black arrows). Four pairs of maxillary plates and one maxilla; $\mathrm{MI}=1+1$, MII

$590=3+3, \mathrm{MIII}=5+0, \mathrm{MIV}=4+6, \mathrm{MV}=1+1$ (Fig. 15F). Branchiae pectinate, from chaetiger $35-$

59147 onwards present as a single filament, reaching up to five to seven filaments in middle

592 chaetigers (Fig. 15B). Dorsal cirri digitform in anterior, middle and posterior chaetigers. Ventral

593 cirri conical in anterior chaetigers and reduces to an oval swelling with a rounded tip in

594 posterior chaetigers. Aciculae blunt with dark brown tips and ends and black shafts (Fig. 15B, E);

Peer] reviewing PDF | (2021:04:59876:2:0:NEW 28 Jun 2021) 
5953 per fascicle in anterior segments, reducing to 2 and then 1 in middle segments; subacicular 596 hooks, light brown tips with black shafts, present from 40th chaetiger with bidentate tips and 597 guards (Fig. 15B, E). Limbate capillaries present in supracicular fascicle throughout (Fig. 15D, E). 598 Pectinate chaetae present in supracicular fascicle; isodont broad blades and fine teeth (Fig. 599 15E). Compound falcigers, bidentate tips, short blades with guards, present in subacicular 600 fascicle (Fig. 15C).

601

Remarks: Specimens collected in this study conform to the general description according to Day 603 (1967). Unfortunately, the original description of M. corallina (Kinberg, 1865a) was poor, with 604 no illustrations against which to compare the specimens collected in this study. However, since 605 the type locality of $M$. corallina is in Hawaii and the species has a global disjunct distribution, it 606 is probable that the specimens collected here are really an incorrectly identified indigenous species. We therefore take the more conservative route and refer to the species collected in South Africa as M. cf. corallina. All specimens collected during this study were incomplete, missing their posterior ends, so characters such as anodont chaetae, the number of branchial filaments and the number of aciculae in the posterior regions were not documented and thus could not be commented on.

612

All sequences generated clustered with M. corallina from KwaZulu-Natal (KT823410) (Kara, 2015), with high bootstrap support, indicating that it is a single species (Fig. 16). Further investigation is underway to confirm the taxonomic status of M. corallina in South Africa.

Collection method: By hand from sediment under rocks.

Known distribution in South Africa: Mabibi in northern KwaZulu-Natal to Mgazana in the Eastern Cape Province, Witsand in Western Cape Province (Day, 1967; current study). Apparent distribution globally: Mozambique, New Zealand, Red Sea, Australia, Marshall Islands, Lakshadweep Island and Juluit Atoll (Day, 1967; Read \& Fauchald, 2021).

622 Ecology: Occupies burrows in sediment under rocks in the mid-intertidal zone. 
624 Species: Marphysa haemasoma Quatrefages, 1866

625 Fig. 17

626

627 Marphysa haemasoma Quatrefages, 1866: 334 - 334, Figs. 4B, 6 \& 7; Grube 1870: 299

628 Marphysa sanguinea Day 1967: 396, fig. $17.5 \mathrm{U}-\mathrm{Y}$ (NOT Montagu, 1815)

629 Marphysa elityeni Lewis \& Karageorgopoulos 2008: 280 - 281, Figs. 1 \&2; Branch et al. 2016 :

630 69, Fig. 2.5

631 Marphysa haemasoma Kara et al. 2020: 16 - 21, Figs 4B, 6 \& 7

632 Common name: Wonderworm, bloukoppies. Listed as estuarine wonderworm in Branch et al. 633 (2016).

634

635

Material examined: Knysna: $34^{\circ} 02^{\prime} 17.5^{\prime \prime} \mathrm{S} 23^{\circ} 02^{\prime} 23.4^{\prime \prime E}, 2$ specimens (incomplete), MB-

636 A090326, MB-A090328), 29 January 2017, coll. A. N. du Toit. Betty's Bay: 34²2'S 1851'E, 5 specimens (incomplete), MB-A090331, MB-A090333 - MB-A090335, MB-A090338), 3 June 2016, digging with a trowel in mid-intertidal rock pools, coll. E. Newman. Strand: $34^{\circ} 07^{\prime} 03.2^{\prime \prime S}$ 1849'29.4"E, 2 specimens, MB-A090271, MB-A090315), 13 January 2017, digging with trowel in gravel under rocks in the mid-intertidal, coll. A. N. du Toit. Soetwater: 3409'33.0"S 18¹9'40.7"E, 5 specimens (incomplete specimens), MB-A090272 - MB-A090275, MB-A090317, 10 March 2017, under rocks in mid-intertidal rock pools, coll. A. N. du Toit. Melkbosstrand: 334' 40.3"S 18²6'17.6"E, 4 specimens (incomplete), MB-A090267 - MB-A090270), 26 February 2017, under rocks in mid-intertidal rocky reef, coll. A. N. du Toit and C. Naidoo.

Description: Body length more than $470 \mathrm{~mm}$. In life body colour variable: dark brown/red anterior with white iridescent spots for about 7 chaetigers (Fig. 17A), becoming medium brown in middle and darker towards the posterior. Specimens from Knysna and Betty's Bay with blue colouration in anterior for about 6 chaetigers (Fig. 17B, white arrow), becoming light brown in middle to posterior. Body iridescent in all specimens. Prostomium bilobed, lobes frontally 651 rounded, sulcus deep (Fig. 17A, B). Prostomial appendages in semi-circle with a brown band just 652 before the tapering ends in live specimens; pair of palps reaching first peristomial ring, pair of 
653 lateral antennae extending to second segment and one median antenna reaching first chaetiger 654 (Fig. 17A, B). Pair of eyes under the lateral antennae. Four pairs of maxillary plates and a maxilla 655 (variation); $\mathrm{MI}=1+1, \mathrm{MII}=3(4)+4, \mathrm{MIII}=5+0, \mathrm{MIV}=3+5, \mathrm{MV}=1+1$ (Fig. 17C). Branchiae 656 pectinate, present from chaetiger 26 onwards as two filaments, reaching a maximum of 8 657 filaments in middle, reducing to a single filament in middle to posterior, absent in posterior end 658 near pygidium. Acicula black (Fig. 17E) throughout, five per fascicle in anterior chaetigers, 659 reducing to three in posterior; subacicular hooks not observed. Simple capillaries and pectinate 660 chaetae present in supracicular fascicle. Four types of pectinate chaetae; isodonts with fine 661 teeth and symmetrical blades (Fig. 17F) in anterior segments and anodonts with medium and 662 coarse teeth (Fig. 17D, G) in middle to posterior chaetigers. Compound spinigers with short and 663 long blades present in subacicular fascicle throughout.

\section{4}

Remarks: Specimens collected here conformed to the description by Kara et al. (2020), except for those collected from Knysna and Betty's Bay which have a blue anterior (approximately first six chaetigers), becoming light brown in the middle to posterior end. Phylogenetic analysis recovered a single well-supported clade that comprised all specimens from Knysna, Betty's Bay, Strand, Kommetjie (Soetwater) and Melkbosstrand, indicating that the colour morphs are a single species (Fig. 16). Lewis \& Karageorgopolous (2008) observed colour variation in specimens which included iridescent blues and greens for the reproductive segments along the length of the body, from chaetigers $70-80$. This does not conform to the colour morphs found in the specimens in the present study in which the colour was observed in the anterior regions. Nonetheless, the colour on the remaining parts of the body, "medium brown in the middle and darker toward the posterior", conform to that reported by Lewis \& Karageorgopolous (2008).

677 The use of two species of Marphysa in the Western Cape Province supports recent research 678 showing that globally, multiple species of this genus, especially members of the $M$. sanguinea 679 complex, are used as bait, even within regions (see review by Hutchings \& Lavesque, 2021). 680 Although the current study showed that different colour morphs represent a single species, 
681 further research is needed to determine whether individuals occupying different habitats, as

682 described by Day (1967) and Lewis \& Karageorgopoulos (2008), are also a single species.

683

684 Collection method: By hand from sediment under boulders in boulder fields.

685 Type locality: Cape of Good Hope, Western Cape, South Africa.

686 Known distribution in South Africa: Langebaan Lagoon on the west coast to Port Elizabeth on

687 the south coast (Day, 1967; Kara et al., 2020).

688 Ecology: Occupies burrows in sediment typically grey/black medium to coarse grains and rich in 689 sulphur. In Knysna, specimens were found in sandier sediments.

690

691 Genus: Lysidice Lamarck, 1818

692 Species: Lysidice natalensis Kinberg, 1865

693 Fig. 18

694

695

Lysidice natalensis Kinberg, 1865: 566; Hartman 1948: 84, 85, PI. XI Figs 1 - 2; Day 1951: 40; Day 696 1953: 435; Day 1960: p336; Day 1967: 401, Fig. 17.7 K - R; Branch et al. 2016: 70, Fig. 26.9

Lysidice atra Schmarda, 1861

698

Lysidice capensis Grube, 1868: 12, Fig. 4; Day 1934: 53

699

Common name: Musselworm. Listed as three-antennaed worm in Branch et al. (2016).

700

701

Material examined: Witsand: 34²3'31.9"S 2051'50.1"E, 11 specimens (2 complete), MB-

702

A090281 - MB-A090289, MB-A090291, MB-A090292, 30 April 2017, from under rocks, in rock

703

pools in mid-intertidal zone, coll. A. du Toit.

704

705

Description: Complete specimens 62 and $63 \mathrm{~mm}$ long for 126 and 156 chaetigers. L10 5.28 - 9.8 $\mathrm{mm}, \mathrm{W} 101.84-4.5 \mathrm{~mm}$. Colour reddish-brown with white spots, both extending into middle of prostomium and antennae, margin of prostomium and tips and base of antennae white (Fig. 18A). Prostomium bilobed, antennae tapered, lateral antennae shorter than prostomium, median antenna slightly longer, proximal part brown, tips white (Fig. 18A). Mandibles thick; MI 
710 1 + 1; MII 3 + 3; MIII 2-3 + 0; MIV 2-3 +4-7; MV 1 + 1. Parapodia with slender dorsal cirri (Fig.

711 18B), becoming shorter and thinner from chaetiger 22 to 38 onwards (Fig. 18E, H). Ventral

712 cirrus bluntly triangular (Fig. 18B), getting shorter posteriorly (Fig. 18E), nipple-shaped in

713 posteriormost chaetigers (Fig. 18H). Post-chaetal lobe truncate (Fig. 18B), getting shorter

714 posteriorly (Fig. 18E), inconspicuous in posteriormost chaetigers (Fig. 18H). Superior chaetae

715 limbate capillaries and comb chaetae of two sizes (Fig. 18F). Inferior compound chaetae with

716 short blades, bidentate, teeth usually of similar sizes (Fig. 18C, D), but proximal tooth may be

717 thicker and or longer. Acicula black with blunt tips, one in anterior chaetigers, two in middle

718 and posterior (Fig. 18B, E, H); bidentate acicula hook with small hood from chaetiger $25-28$

719 onwards (Fig. 18E, H), teeth may be worn, giving unidentate appearance (Fig. 18G).

720

721

Remarks: Original description by Kinberg (1865a) is poor, but this material is later described by

722 Hartman (1948). Specimens collected here generally match this latter description, and those by

723 Day $(1951,1953,1967)$, although the posterior ventral cirrus is more prominent than described by Day (1967). The wide distribution within South Africa is suggestive of multiple species and

725

726

727

728

729

730

731

732

733

734

735

736

737

738 may be further reflected by the two species that Day (1967) synonymised with L. natalensis without explanation. It is therefore possible that L. capensis and L. atra, both originally described from the temperate Western Cape Province in Kalk Bay and the Cape of Good Hope, respectively, are not $L$. natalensis which was first described from Durban in the subtropical KwaZulu-Natal. Additionally, Day (1967) provides no explanation for why L. atra, which was described four years before $L$. natalensis and therefore claims priority, was synonymised with the latter. More specimens from throughout the distribution range and any available type material need to be examined to resolve the taxonomy of this species. The description of $L$. natalensis from Pakistan by Mustaquim (2000) is not very detailed, and the only differences from samples examined here are differently shaped post-chaetal lobes. All specimens from Witsand form a well-supported clade that is not reciprocally monophyletic with L. natalensis from India (Fig. 16; Sigamani et al., 2020). Identity of the species in Pakistan is also doubtful.

\footnotetext{
Collection method: By hand.
} 
739 Type locality: Durban, KwaZulu-Natal, South Africa.

740 Known distribution in South Africa: From Namibia to northern KwaZulu-Natal (Day 1967).

741 Ecology: Habitat variable; in the current study specimens were collected from under rocks in

742 rock pools, Day (1934) reported them from muddy sand.

743

744 Family: Onuphidae Kinberg, 1865

745 Genus: Heptaceras Ehlers, 1868

746 Species: Heptaceras quinquedens (Day, 1951)

747 Fig. 19

748

749 Onuphis quinquedens Day, 1951: 40 - 42, Fig. 6A - H; Day 1967: 422, Fig. 17.13A - E; Fauchald 750 1982: 100, Fig. 28B

751 Heptaceras quinquedens Paxton 1986: 58 - 60, Fig. 36I, J

752 Common name: moonshineworm.

753

754

Material examined: Pearly Beach: 3440'00.5"S 19²9'42.7"E, 5 specimens (incomplete), MB-

755 A090432 - MB-A090436, 23 January 2017, coll. H. van Rensburg \& A. du Toit. Strand beach: 3406'37.6"S 1849'14.6"E, 1 specimen (incomplete), MB-A090442, 13 January 2017, coll. H. van Rensburg and A. du Toit. Struisbaai Main Beach: 3447'32.3"S 2002'54.8"E, 15 specimens

(incomplete), MB-A090421 - MB-A090431, MB-A090437 - MB-A090440, 27 January 2017, coll.

H. van Rensburg, A. du Toit and C. Naidoo.

760

761

Description: Large species reaching $350 \mathrm{~mm}$ in length and $6 \mathrm{~mm}$ width at $10^{\text {th }}$ chaetiger. Anterior section rounded, becoming dorso-ventrally flattened and ventrally convex from chaetiger 3- 6 onward (Fig. 19D). In life, prostomium and peristomium white (Fig. 19B), rest of body pale, white-brown ventrally and more reddish-brown dorsally (Fig. 19E), becoming paler towards median and posterior sections, dorsum covered with small red-brown spots, more prominent towards anterior (Fig. 19B). Irregularly spaced red-brown or black dots on ceratophoral rings with a single white patch within final elongated distal ring (Fig. 19B). All colouring disappears 
768 after preservation (Fig. 19A, C, D). Iridescent shine observed over entire body in live and 769 preserved specimens (Fig. 19A - D).

770 Prostomium with frontal extension forming palpohores for frontal palps (Fig. 19C). Lateral 771 antennae reaching chaetiger $4-7$ on posterior part of prostomium, shorter median antenna 772 reaching chaetiger $2-4$ placed anterior to lateral antennae. Proximal ceratophoral rings wide, 773 covering most of prostomium (Fig. 19A). Ceratophores with 15 - 30 rings on median antennae 774 and $20-48$ rings on lateral antennae, each terminating in an elongated distal ring.

775 Ceratophores at least as long as styles but up to twice the length of styles which taper distally 776 (Fig. 19B, D). Peristomium as long as, or longer than, prostomium with deep mid-dorsal notch 777 on the dorsal margin, flanking an elevated prostomial ridge (Fig. 19A). Peristomial cirri as long 778 as peristomium, slender and tapering, situated distally on peristomium on either side of the 779 mid-dorsal notch, curving laterally (Fig. 19A, B).

780 Parapodia mounted marginally, anterior three pairs projecting anteriorly, slightly elongated

781 (Fig. 19B, D) and modified with four or five hooded bi- or tridentate pseudo-compound falcigers

782 (Fig. 19G), remaining parapodia directed dorsally. Dorsal cirri simple tapering filament

783 anteriorly with small basal process towards posterior end (Fig. 19H), shorter than branchiae

784 (Fig. 19D, F). Ventral cirri subulate on anterior five chaetigers changing to pad-like globular form

785 (Fig. 19D). Pectinate chaetae from chaetiger $6-8$ with $22-28$ teeth (Fig. 19J). Superior limbate 786 chaetae from chaetiger 1. Branchiae start as simple tapered filaments on chaetiger 1 (Fig. 19D), 787 become pectinate on chaetiger $8-10$ with maximum of $7-12$ filaments per branchia (Fig. 19F), 788 continuing throughout rest of body (Fig. 19E). Hooded bidentate acicular chaetae appear from $78910^{\text {th }}$ chaetiger to the end of the body (Fig. 19I).

790

791 Remarks: The specimens examined here match earlier descriptions (Day, 1951; Day, 1967;

792 Fauchald, 1982), but this is the first observation of tridentate falcigers in the modified 793 parapodia, although tridentate falcigers are known to occur within the genus (Paxton, 1986). 794 The third tooth is small (Fig. 19G) and not always present so can easily be overlooked. 795 According to Fauchald (1982) the median antenna is longer than the posterior lateral ones in 796 the holotype (reaching chaetiger three vs. two) but in all of the material examined here, the 
797 posterior lateral antennae were longer than the median antenna, conforming to the description 798 by Paxton (1986). The iridescent shine seen on the body of $H$. quinquedens is similar to that of 799 Diopatra aciculata (van Rensburg, Matthee \& Simon, 2020) and may be why fishermen 800 commonly refer to both species as moonshineworms.

801

802 Collection method: "prawn pumps" during low tide.

803 Type locality: Umpangazi, KwaZulu-Natal, South Africa.

804 Known distribution in South Africa: Western Cape Province to KwaZulu-Natal (Day, 1967).

805 Apparent distribution globally: report in India (Sigamani et al., 2020) needs to be confirmed.

806 Ecology: They build temporary tubes in the intertidal of sandy beaches, but do not build 807 conspicuous chimneys.

808

809 Order: Phyllodocida Dales, 1962

810 Family: Nereididae Blainville, 1818

811 Genus: Perinereis Kinberg, 1865b

812 Species: Perinereis latipalpa (Schmarda, 1861)

813 Fig. 20

814

815 Nereis (Nereis) latipalpa Schmarda, 1861: 104 - 105, txt-fig. A, B, Ka \& b, PI. 31,244

816 Neanthes latipalpa Kinberg, 1865b: 171; von Marenzeller 1888: 6 - 7, Fig. 2

817 Neanthes latipalpa typica Willey, 1904: 260 - 261, PI. 13, Fig. 9, PI. 14, Fig. 1 - 2, 2a \& b

818 Perinereis nuntia vallata Day 1967: 334, Fig. 14.12 P - S; Branch et al. 2016: 67, Fig. 25.4 (NOT

819 Grube \& Kroyer in Grube 1858).

820 Perinereis namibia Wilson \& Glasby, 1993: 265 - 266, Fig. 10A - K.

821 Perinereis latipalpa Villalobos-Guerrero 2019: 474 - 483, Figs 3 - 7.

822 Common name: Coralworm. 
824 Material examined: Kommetjie: $34^{\circ} 08^{\prime} 34.5^{\prime \prime S} 18^{\circ} 19^{\prime} 20.4^{\prime \prime E}, 3$ specimens (complete), MB825 A090297 - MB-A090299), 10 March 2017, under rocks in the mid-intertidal zone, coll. A. N. du 826 Toit.

827

Description: Body up to $170 \mathrm{~mm}$. Live specimens, body colour dark green in anterior region, light brown in the middle, to a pale yellow in the posterior. Red blotchy pigment in the middle of each segment, prominent from chaetiger 7-10 onwards (Fig. 20A, B, black arrows). Rectangular palpophores with rounded palpostyles. Two antennae, slender with tapering ends (Fig. 20A, D). Two pairs of black eyes in a trapezoidal arrangement (Fig. 20A). Maxillary ring with conical paragnaths (Fig. 20C), Area I = 1-2, Area II (variation) $=4(9)+6(10)$, Area III = $11-17$ in an oval patch, Area IV = 8(33) $+16(32)$, spoon shaped patch. Oral ring with conical paragnaths (Fig. 20D, E), Area $V=1$, Area $\mathrm{VI}=8(10)+9(12)$ in a long arc, Area VII - VIII = $34-58$ cones in two irregular rows. Dorsal and ventral cirri present throughout. Notochaetae, homogomph spinigers with serrated blades, first 3 teeth at the base of the blade larger, becoming smaller and uniform till the tip (Fig. 20F, hoS). Neurochaetae, homogomph, heterogomph spingiers with serrated blades, uniform teeth (Fig. 20E, heS) and heterogomph falcigers with medium sized blades, finely serrated (Fig. 20G).

Remarks: Specimens collected in this study conformed to the recent redescription in VillalobosGuerrero (2019). However, variation in body size and paragnath arrangement was noted; total length of paratype is $127 \mathrm{~mm}$ and paragnath arrangement, Area III = 9, Area IV = 18-23, Area VII $-\mathrm{VIII}=53$.

846

Collection method: From under rocks in the mid-intertidal zone.

Type locality: Table Bay, Cape of Good Hope, South Africa.

Known distribution in South Africa: Hondeklip Bay on the west coast to Port St Johns on the east 
853 Genus: Pseudonereis Kinberg, 1865b

854 Species: Pseudonereis podocirra (Schmarda, 1861)

855 Fig. 21

856

857 Mastigonereis podocirra Schmarda, 1861: 108, Fig. 217.

858 Nereis (Nereilepas) stimpsonis Grube, 1866: 176.

859 Pseudonereis variegata Day 1967: 331, Fig. 14.12A - F (NOT Grube \& Kröyer, 1858); Branch et 860 al., 2016: 66, Fig. 25.1

861 Pseudonereis podocirra Kara, Macdonald \& Simon 2018: 1286 - 1291, Figs 2 - 4

862 Common name: Musselworm.

863

864

Material examined: Velddrif: 3408'34.5"S 18²19'20.4"E, 9 specimens (incomplete), MBA090355, MB-A090359, MB-A090361 - MB-A090363, MB-A090365, MB-A090366, MBA090372, MB-A090373), 26 May 2017, from rock pools in the mid-intertidal, coll. A. N. du Toit. Betty's Bay: 34²2'39.6"S 1851'21.6"E, 3 specimens (incomplete), MB-A090302, MB-A090304, MB-A090305, 10 February 2017, from under mussel beds in the mid-intertidal mussel belt, coll. A. N. du Toit. Hermanus: $34^{\circ} 24^{\prime} 41.1^{\prime \prime S} 19^{\circ} 16^{\prime} 44.8^{\prime \prime E}, 6$ specimens (incomplete), MB-A090306 MB-A090310, MB-A090443, 11 February 2017, from under mussels in the mid-intertidal mussel belt, coll. A.N. du Toit and H. van Rensburg.

872

Description: Body length up to more than $140 \mathrm{~mm}$. Colour variable: greenish-brown, greyishbrown and medium brown (Fig. 21A, B) with white pigmented spots around 4 eyes on prostomium. Black pigmented spots along midpoint of segment boundaries from chaetiger 13

876 (Fig. 21B). A mix of different types of paragnaths; conical, shield-shaped and p-bars; arranged in 877 distinct areas on pharynx. Area I = 1 conical, Area II = 15-17 conical in a wedge shape, Area III $878=22$ conical in three-four rows, Area IV = 27 - 32 conical and p-bars in a closely spaced arc 879 shape, Area V = 1 conical, Area VI = large shield-shaped bars and Area VII - VIII = 40 conical and 880 p-bars alternating in $2-4$ rows (Fig. 21C). Oral ring (Fig. 21C), AVI-V-AVI pattern, $v$-shaped: 
882 elongated from chaetiger 13 to posterior (Fig. 21F). Dorsal and ventral cirri present (Fig. 21F).

883 Homogomph spinigers with finely serrated blades (Fig. 21E) and heterogomph falcigers (Fig.

884 21D) with concaved and finely serrated blades.

885

886

Remarks: Specimens collected in the study conformed to the redescription in Kara, Macdonald

887

\& Simon (2018), except for body length which was larger, measuring up to a maximum of 140

888

mm. Molecular analyses (Fig. 22) recovered a single monophyletic group with strong maximum

889

likelihood support, indicating a single genetically similar population, further supporting Kara,

890

Macdonald \& Simon (2018). Synonymy of $P$. podocirra with $P$. variegata was recently reversed

891

(Kara, Macdonald \& Simon 2018), but it is not known whether P. variegata in KwaZulu-Natal in

892

South Africa, Namibia and Mozambique, as reported by Day (1967), are a single species.

893

894

Collection method: Breaking off mussels by hand from the mussel bed, or by pouring household

895

bleach over the bed (ADT; pers. obs.). Collection of nereidid species is no longer permitted

896

(DAFF 2017).

897

Type locality: Cape of Good Hope, Western Cape, South Africa.

898

Known distribution in South Africa: Lamberts Bay to Kidds Beach (Kara, Macdonald \& Simon,

899

2018), possibly extending up the east coast to KwaZulu-Natal and Mozambique and up the west

900

coast to Namibia (Day, 1967).

901

Ecology: In low intertidal among mussel beds and abandoned Gunnarea tubes and barnacle

902 shells.

903

904

Discussion

905

This study found that more marine annelid taxa are utilised in South Africa as bait than what

906 has previously been reported. In addition to the widely reported and investigated bait species

907

(Arenicola loveni, Gunnarea gaimardi, Marphysa haemasoma and Pseudonereis podocirra; e.g., 908 van Herwerden, 1989; Lewis 2005; Sowman, 2006; Lewis \& Karageorgopoulos, 2008; Branch et al., 2016), several taxa were recorded for the first time (Abarenicola gilchristi, Gunnarea sp. 1, Heptaceras quinquedens, Lysidice natalensis, Marphysa cf. corallina, Perinereis latipalpa, 
911 Scoletoma spp 1 and 2). This is also the first published report of Siphonosoma dayi being used,

912 even though there have been anecdotal reports of fishermen collecting sandworm in Knysna

913 since at least 2009 (M.K.S. Smith, South African national Parks, Knysna, pers. comm.). By

914 contrast, Arabella iricolor and Eunice aphroditois (or species matching their general

915 descriptions), which are listed as bait in legislation and field guides (Marine Living Resources

916 Act, 2014; Branch et al., 2016), were not collected in this study. This suggests that more species

917 are used in the province than collected by us, possibly because these species did not occur at

918 the sites sampled, and or that identifications of these species being used were incorrect. For

919 example, one of the authors never found E. aphroditois in the Western Cape Province even

920 after extensive sampling in apparently appropriate substrate, although she did find Eunice

921 species in the subtidal in KwaZulu-Natal on the east coast (JK, personal observations).

922 Furthermore, $A$. iricolor is superficially similar to lumbrinerid species, and it is possible that both

923 taxa are collected, or that these species were confused in the records for bait collecting.

924 Finally, it is not possible to determine whether species that were collected at single sites ( $L$.

925 natalensis and $P$. latipalpa) are targeted more widely, or were misidentified since both were

926 called by names more widely used for other species.

927

928 Including Diopatra aciculata collected in Knysna in a parallel study (van Rensburg, Matthee \&

929 Simon, 2020), 14 species were identified in the Western Cape Province by ten common names,

930 excluding Afrikaans translations. For species collected multiple times and from different

931 locations, individual common names were sometimes applied to more than one species.

932 Species of the same family or genus were often known by a single common name; for example,

933 arenicolids (Arenicola loveni and A. gilchristi) are bloodworm, onuphids (D. aciculata and $H$.

934 quinquedens) are moonshineworms, Scoletoma species are puddingworms and Marphysa

935 species are wonderworms. For the arenicolids and onuphids this is true even when the species

936 show clear morphological or environmental differences which may have been noted by

937 fishermen, as evidenced by fishermen in Pearly Beach who distinguished between bloodworm

938 (A. loveni) and the bakkiewurm (A. gilchristi). This was the first time that a second arenicolid is 939 reported as bait, even though DAFF (2017) acknowledges that more than one species may be 
940 used when they specify that bloodworm are "All species of the genus Arenicola", although this

941 is inaccurate as only one species of Arenicola has been recorded locally. Individual species were

942 sometimes called by multiple common names that were not translations of the same thing. For

943 example, M. haemasoma was identified as wonderworm, bloodworm or bloukoppie (this is

944 Afrikaans for 'blue head', referring to the blue anterior of worms from Knysna and Betty's Bay);

945 G. gaimardi was identified as coralworm and polwurm ('pol' is Afrikaans for a tuft, tussock or

946 clump of grass, and may here refer to the clumps of tubes formed by the worms); P. podocirra

947 was identified as musselworm and coralworm, while D. aciculata was also called the

948 pypiewurm (this is Afrikaans for 'pipe worm', undoubtedly alluding to the chimneys that extend

949 from the mouths of the tubes) by bait collectors in Port Elizabeth (van Rensburg, Pers. Obs.). It

950 is also apparent that individual common names were sometimes applied to species from

951 different families, such as coralworm (G. gaimardi, P. latiplapa, P. podocirra) and musselworm

952 (P. podocirra, L. natalensis).

953

954 For the most part, subsistence and recreational fishermen used the same names (e.g., for

955 arenicolids, sabellarids, onuphids and Marphysa species). Variations in use of names may

956 suggest unfamiliarity with bait worms among some subsistence fishermen, such as bloodworm

957 for M. haemasoma in Melkbosstrand, or differences in the use of names depending on

958 geographic region and or type of fishermen, such as coralworm for nereidids at Kommetjie and

959 Velddrif. Interestingly, none of the fishermen used the names from Branch et al. (2016) for $M$.

960 haemasoma (estuarine wonderworm which distinguishes it from E. aphroditois, the

961 wonderworm), G. gaimardi (Cape reef-worm), L. natalensis (three-antennaed worm) or

962 Scoletoma species (S. tetraura false earthworm). Finally, several common names that appear in

963 DAFF (2017), such as rock, shingle, or pot worms, were not used for any of the species collected

964 in this study. The results of this study confirm that common names are sometimes applied in an

965 inconsistent manner by managers and bait collectors. These differences may be maintained

966 through the transfer of knowledge, across generations of bait collectors, of the identification of

967 worms by morphology and ecological patterns. However, it is possible that the application of 
968

969

970

971

972

973

974

975

976

977

978

979

980

981

982

983

984

985

986

987

988

989

990

991

992

993

994

995

996

common names has changed (e.g., the name moonshineworm applied to onuphids and not $A$.

iricola (Marine Living Resources Act, 2014)).

The genetic data confirmed the presence of complexes of morphologically similar species within South Africa and globally. Day (1967) reported Gunnarea gaimardi and S. tetraura from Namibia to northern KwaZulu-Natal. Given that this range spans the cold Namaqua, warm Agulhas, and subtropical Natal ecoregions (Sink et al., 2018) and barriers to gene flow at Cape Point, Cape Agulhas, Algoa Bay and Wild Coast (Teske et al., 2011), it is not surprising that these nominal species each included two genetically distinct species with geographic and habitat separation, respectively. This may also apply to L. natalensis that has a similar distribution (Day, 1967; Branch et al., 2016). Even though all specimens identified here as Gunnarea (including Gunnarea sp. and G. gaimardi) and the Scoletoma species from Hermanus and Betty's Bay matched the descriptions of the nominal species provided in Day (1967; G. gaimardi and S. tetraura, respectively), the two genetic groups identified in each could be easily distinguished after thorough morphological examination. This supports Hutchings \& Kupriyanova (2018) who suggested that many descriptions contained in Day (1967), especially of species described before the 1900s such as the two species under discussion, are too generic to enable accurate identification. Similarly, sequences of L. natalensis and Scoletoma species 1 and 2 generated in this study do not match those generated for L. natalensis and S. tetraura collected in India and China, respectively (Zhou et al., 2010; Sigamani et al., 2020; Unpublished data: Chen et al., 2017; Yao et al., 2017; Xing \& Zang 2020), indicating the presence of complexes of species that may be morphologically similar but genetically distinct, from different locations around the world. Sigamani et al. (2020) used Day (1967) to identify their samples which also included $H$. quinquedens, originally described from South Africa; unfortunately, we were unable to obtain sequences for the samples that we gathered to test whether the specimens from the two countries are conspecific. However, our results again support Hutchings \& Kupriyanova (2018) who warned that using Day (1967) to identify polychaetes outside of southern Africa may erroneously inflate the distribution ranges of polychaete species. 
997 Resolving the identities of marine annelids used as bait has several important management 998 implications. This is exemplified by the recent discovery that moonshineworm collected in 999 Swartkops and Knysna estuaries is D. aciculata, a species originally described in Australia and is 1000 probably an alien in South Africa (Elgetany et al., 2020; Van Rensburg et al., 2020). Thus, the 1001 focus of management of this species must change from conserving populations to preventing 1002 further population growth and spread (Van Rensburg, 2019; Van Rensburg et al. 2020). This 1003 could be done by permitting increased removal by bait collectors, but preliminary investigations 1004 1005 suggest that this is unfeasible (van Rensburg, 2019) and that alternative management strategies need to be explored. Knowing the identity of the worms used may also have important implications for the movement of bait species between sites where worms are collected and where fish are caught, since unused bait that can regenerate is frequently discarded in the latter (M.K.S. Smith, South African National Parks, Knysna). This is especially important if the species is alien (as D. aciculata), or if species thought to be locally widespread are multiple species with restricted distributions (as may be the case for Gunnarea, Scoletoma and Lysidice species).

1012

The disjunction between the common names used by collectors and managers is especially problematic when considering the worms that should not be collected. The most recent brochure issued by DAFF (2017) states that Cape reef worm (specified as Gunnarea), cannot be collected, but that coralworm can. Since collectors contributing to this study all called Gunnarea coralworm, and because it is unlikely that many would know the genus name, bait collectors could collect this species not knowing that they are breaking the law (or use it as a defence if they do). The prohibition on collection of Gunnarea and musselworms (identified as Nereis and Pseudonereis by DAFF (2017)) is related to the structural damage caused to reefs and mussel beds during collection (van Herwerden, 1989), although this is not clearly articulated in the information brochure. It may therefore be more effective to specify the prohibition of taxa based on the habitats that they occupy, and not just name. 
1025 This study was limited by several constraints. Firstly, the geographical coverage was restricted 1026 relative to the total coastline of the province; the fishing sites were selected according to where 1027 participants could be recruited in advance (because bait collecting is time consuming and needs 1028 to coincide with low tides which further limited sampling opportunities, we contacted a core of 1029 the participants via fishing mailing lists to ensure success in collection) while we also avoided 1030 sites that were potentially unsafe, such as Strandfontein and Monwabisi beaches along the

1031

1032

1033

1034

1035

1036

1037

1038

1039

1040

1041

1042

1043

1044

1045

1046

1047

1048

1049

1050

1051

1052

1053 northern shores of False Bay. Because of this sampling strategy, there was a bias towards recreational fishermen because subsistence fishermen could not be contacted in advance. Instead, subsistence fishermen were approached on an ad hoc basis if they were active at the preselected sampling sites. Additionally, many subsistence fishermen were unwilling to donate bait to the project because bait collecting is so time consuming. We were also reluctant to offer compensation to fishermen because the sale of worms is prohibited by law (Marine Living Resources Act, 2014). Consequently, our understanding of the use of common names is still incomplete because species reportedly used as bait, but not found, could not be addressed in this study. This is further exacerbated when fishermen from different fishing sectors and who speak different languages (e.g., English, Afrikaans, isiXhosa) use different names.

In conclusion, the current study has confirmed that more polychaete species are currently used as bait than previously reported. Furthermore, the inconsistent application of common names across taxa and among users, including for the more popular and widespread species, may hamper effective management. The detection of pseudocryptic species complexes among some bait species may have further implications for the management of these taxa as individual species should form separate management units, especially if they are spatially separated. Finally, diversity of marine annelids in general, and bait species in particular, has been underestimated in South Africa, and the global distribution of some has been overestimated. Research to clarify the taxonomy of the members of the pseudocryptic species complexes identified here, i.e., Scoletoma species 1 and 2 and Gunnarea sp. 1, and the use of polychaetes and common names across a wider geographic range is ongoing. 


\section{Acknowledgements}

1055 The authors thank Amy Williams for assisting with processing samples, Teresa Derbyshire for 1056 commenting on descriptions of the arenicolids, Breyten van der Merwe, Celeste du Toit, the 1057 many fishermen who were so generous with their time and expertise, and two anonymous 1058 reviewers whose feedback greatly improved the quality of the manuscript.

\section{Additional information and declarations}

1060 Author contributions

1061 CAS: Conceived and funded project, processed samples and wrote the manuscript

1062 JK: Processed and analysed samples and contributed to writing the manuscript

1063 HvR: Collected and processed samples and contributed to writing the manuscript

1064 AdT and CN: Collected and processed samples

1065 CAM: Co-supervised student authors, and participated in analysis of samples and editing final 1066 document.

1067

1068 References

1069 Ashworth JH. 1911. The Arenicolidae of South Africa, including an account of Arenicola 1070 loveni Kinberg. Annals of the South African Museum 11(1):1-27, plate I

1071 Allanson BR, Human, LRD, Claassens L. 2016. Observations on the distribution and abundance 1072 of a green tide along an intertidal shore, Knysna Estuary. South African Journal of Botany 1073 107:49-54

1074

1075

1076

1077

1078

1079

1080

1081

1082

Audouin JV, Milne Edwards H. 1832. [Part 1] Classification des Annélides et description de celles qui habitent les côtes de la France. Annales des Sciences Naturelles, Paris. 1(27):337-447.

Audouin JV, Milne Edwards H. 1833. [Part 2.] Classification des Annélides et description de celles qui habitent les côtes de la France. Annales des Sciences Naturelles, Paris. 1(28):187-247.

Berthold AA. 1827. Naturliche Familien des Thierreichs aus dem Franzosischen. Mit Anmerkungen und Zusätzen. Landes-Industrie Comptoirs, Weimar, x +606 pp.

Blainville H M D de. 1818. Mémoire sur la classe des Sétipodes, partie des Vers à sang rouge de M. Cuvier, et des Annélides de M. de Lamarck. Bulletin des Sciences, par la Société Philomatique de Paris. 1818, 3:78-85 
1083 Blainville H. M. D de. 1828. Mollusques, Vers et Zoophytes [entries in VEA-VERS, volume

1084

1085

1086

1087

1088

1089

1090

1091

1092

1093

1094

1095

1096

1097

1098

1099

1100

1101

1102

1103

1104

1105

1106

1107

1108

1109

1110

1111

1112

57]. In: Dictionnaire des Sciences naturelles, dans lequel on traite methodiquement des differens etres de la nature, consideres soit en eux-memes. d'apres l'etat actuel de nos connais sciences, soit relativement a l'utilite qu'en peuvent retirer la medicine, l'agriculture, le commerce et les arts. Suive d'une biographie des plus celebres naturalistes. vol. 57 [Tome LVII. Vea - Vers] F.G. Levrault, Strasbourg \& Paris.

Bleidorn C, Vogt L, Bartolomaeus T. 2005. Molecular phylogeny of lugworms (Annelida, Arenicolidae) inferred from three genes. Molecular Phylogenetics and Evolution 34:673-679.

Branch GM, Griffiths CL, Branch ML, Beckley LE. 2016. Two Oceans: A Guide to the Marine Life of Southern Africa. Cape Town: Penguin Random House South Africa. 456 pp.

Capa M, Hutchings P, Peart R. 2012. Systematic revision of Sabellariidae (Polychaeta) and their relationships with other polychaetes using morphological and DNA sequence data. Zoological Journal of the Linnean Society 164:245-284.

Carrera-Parra LF. 2001. Lumbrineridae (Annelida: Polychaeta) from the Grand Caribbean region with the description of six new species. Journal of the Marine Biological Association of the United Kingdom 81(4):599-621

Dales RP. 1962. The polychaete stomodeum and the inter-relationships of the families of Polychaeta. Proceedings of the Zoological Society 139:389-428.

Darbyshire T. 2017. A re-evaluation of the Abarenicola assimilis group with a new species from the Falkland Islands and key to species. Journal of the Marine Biological Association of the United Kingdom 97(5):897-910 doi:10.1017/S0025315417000741

Day JH. 1934. On a collection of South African Polychaeta with a catalogue of the species recorded from South Africa, Angola, Mozambique and Madagascar. Journal of the Linnean Society, Zoology 39:15-82

Day JH. 1951. The polychaete fauna of South Africa. Part 1. The intertidal and estuarine Polychaeta of Natal and Mozambique. Annals of the Natal Museum 12(1):1-67

Day JH. 1953. The polychaete fauna of South Africa. Part 2: Errant species from Cape shores and estuaries. Annals of the Natal Museum 12(3):397-441

Day JH. 1960. The polychaete fauna of South Africa. Part 6: Sedentary species dredged off Cape coasts with a few records from inshore. Annals of the South African Museum 45:261-373.

Peer) reviewing PDF | (2021:04:59876:2:0:NEW 28 Jun 2021) 
1113 Day JH. 1963. The polychaete fauna of South Africa. Part 8: New species and records from grab 1114 samples and dredgings. Bulletin of the British Museum (Natural History), Series Zoology. 10(7): 1115 381-445

1116 Day JH. 1967. A monograph on the Polychaeta of Southern Africa. British Museum of Natural 1117 History Publications 646:1-878.

1118 Day JH. 1974. A guide to marine life on South African shores. $2^{\text {nd }}$ Edition. A.A. Balkema, Cape 1119 Town/Rotterdam. 300 pp.

1120 (DAFF) Department of Agriculture, Forestry and Fisheries. 2017. Marine Recreational Activity 1121 Information Brochure. http:// www.daff.gov.za/daffweb3/Branches/Fisheries-

1122 Management/Marine-Resource-Management/Recreational-Fishing

1123 Ehlers E. 1868. Die Borstenwürmer (Annelida Chaetopoda) nach systematiechen und 1124 anatomosichen Untersuchgen dargestelt. Engelmann, Leipzig, pp 269-748

1125 Elgetany AH, van Rensburg H, Hektoen M, Matthee CA, Budaeva N, Simon CA, Struck TH.

1126 2020. Species delineation in the speciation grey zone - the case of Diopatra (Annelida, 1127 Onuphidae). Zoologica Scripta 49(4): 516-534, DOI: 10.1111/zsc.12421

1128 Fauchald K. 1982. Revision of Onuphis, Nothria, and Paradiopatra (Polychaeta:Onuphidae) 1129 based upon type material. Smithsonian Contributions to Zoology. 356:1-120.

1130 Fauvel P. 1950. Contribution a la Faune des Annelides polychetes du Sénégal. Bulletin de 1131 I'Institut Francais d'Afrique Noire 12(2):335-394.

1132 Fielding PJ. 2007. The subsistence bait fishery in the Swartkops Estuary, Port Elizabeth, Eastern 1133 Cape. Analysis of data collected by monitors December 2005-June 2006. Prepared for 1134 Environmental Evaluation Unit, University of Cape Town.

1135 Fisher WK, MacGinitie GE. 1928. A new echiuroid worm from California. Annals and Magazine 1136 of Natural History (Series 10) 1(2):199-204.

1137 Folmer O, Black M, Hoeh W, Lutz R, Vrijenhoek R. 1994. DNA primers for amplification of 1138 mitochondrial cytochrome $c$ oxidase subunit I from diverse metazoan invertebrates. Molecular 1139 Marine Biology and Biotechnology 3(5):294-299.

1140 Gaigher CM. 1979. Aspects of the population dynamics and ecology of the bloodworm 1141 (Arenicola loveni Kingerg). MSc thesis. University of Cape Town, South Africa, 113 pp. 
1142 Gallardo VA. 1968. Polychaeta from the Bay of Nha Trang, South Viet Nam. Naga

1143 Report 4(3):35-279.

1144 Grube AE. 1856 (pub. 1857). Annulata Örstediana. Enumeratio Annulatorum, quae in itinere per Indiam occidentalem et Americam centralem annis $1845-1848$ suscepto legit cl. A.S. Örsted, adjectis speciebus nonnullis a cl. H. Kröyero in itinere ad Americam meridionalem collectis. Videnskabelige Meddelelser fra Dansk naturhistorisk Forening i Köbenhavn [Part 2]:44-62.

Grube A-E. 1857. Annulata Örstediana. Enumeratio Annulatorum, quae in itinere per Indiam occidentalem et Americam centralem annis 1845-1848 suscepto legit cl. A. S. Örsted, adjectis speciebus nonnullis a cl. H. Kröyero in itinere ad Americam meridionalem collectis. (Fortsaettelse). Vidensk. Meddel. Fra. D. naturhist. Foren, Kobenhavn [Part 2]:158-166.

Grube A-E. 1866. Beschreibungen neuer von der Novara-Expedition mitgebrachter Anneliden und einer neuen Landplanarie. Verhandlungen der kaiserlich-königlichen zoologischbotanischen Gesellschaft in Wien 16:173-184

Grube A-E. 1867. Anneliden. Reise der Österreichischen Fregatte Novara um die Erde in den Jahren 1857, 1858, 1859 unter den befehlen des Commodore B. von Wüllerstorf-Urbair. Zoologischer Theil. 2(3.2):1-46, plates I-IV.

Grube AE. 1878. Annulata Semperiana. Beiträge zur Kenntniss der Annelidenfauna der Philippinen nach den von Herrn Prof. Semper mitgebrachten Sammlungen. Mémoires I'Académie Impériale des Sciences de St.- Pétersbourg. (série 7) 25(8):1-300.

Hall TA. 1999. BioEdit: a user-friendly biological sequence alignment editor and analysis program for Windows 95/98/NT. Nucleic Acids Symposium Series 41: 95-98

Hartman 0. 1948. The marine annelids erected by Kinberg with notes on some other types in the Swedish State Museum. Arkiv för Zoologi Stockholm 42(1):1-137

Hodgson AN, Allanson BR, Cretchley R. 2000. The exploitation of Upogebia africana (Crustacea: Thalassinidae) for bait in the Knysna Estuary. Transactions of the Royal Society of South Africa 55(2):197-204.

Hutchings P, Kupriyanova E. 2018. Cosmopolitan polychaetes - fact or fiction? Personal and historical perspectives. Invertebrate Systematics 32:1-9.

1170 Hutchings P, Lavesque N. 2021. I know who you are, but do others know? Why correct scientific names are so important for the biological sciences. Zoosymposia 19:151-163. 
1172 Johansson KE. 1927. Beiträge zur Kenntnis der Polychaeten-Familien Hermellidae Sabellidae

1173 und Serpulidae. [inaugural-dissertation]. Zoologiska Bidrag från Uppsala 11:1-184.

1174 Johnston G. 1835. Illustrations in British Zoology (45 Lernaea uncinata, 46 Arenicola

1175 ecaudata). Magazine of Natural History and Journal of Zoology, Botany, Mineralogy, Geology

1176 and Meteorology. 8:565-569, figs. 53-54. (x-1835)

1177 Johnston G. 1865. A catalogue of the British non-parasitical worms in the collection of the

1178 British Museum. British Museum. London. 365 pp.

1179 Kara J. 2015. A phylogeny of South African east coast intertidal rocky-shore Polychaete worms 1180 (Annelida) and the genetic structure and demographic history of an example, Marphysa 1181 corallina. MSc thesis. University of KwaZulu-Natal, South Africa.

1182 Kara J, Macdonald AHH, Simon CA. 2018. Integrative taxonomic methods reveal an incorrect 1183 synonymisation of the South African Pseudonereis podocirra (Schmarda) as the widespread 1184 Pseudonereis variegata (Grube) from Chile. Invertebrate Systematics 32:1282-1297.

1185

1186

1187

1188

1189

1190

1191

1192

1193

1194

1195

1196

1197

1198

1199

1200

1201

Kara J, Molina-Acevedo IC, Zanol J, Simon C, Idris I. 2020. Morphological and molecular systematic review of Marphysa Quatrefages, 1865 (Annelida: Eunicidae) species from South Africa. PeerJ 8:e10076 http://doi.org/10.7717/peerj.10076

Kawauchi GY, Sharma PP, Giribet G. 2012. Sipunculan phylogeny based on six genes, with a new classification and the descriptions of two new families. Zoologica Scripta 41(2):186-210.

Kinberg JGH. 1865a. Annulata nova. Öfversigt af Königlich Vetenskapsakademiens förhandlingar, Stockholm 21(10):559-574.

Kinberg JGH. 1865b. Annulata nova. [Continuatio.]. Öfversigt af Königlich Vetenskapsakademiens förhandlingar, Stockholm 22(2):167-179.

Kinberg JGH. 1866. Annulata nova. [Continuatio.]. Öfversigt af Königlich Vetenskapsakademiens förhandlingar, Stockholm. 23(9):337-357.

Kirtley DW. 1994. A review and taxonomic revision of the family Sabellariidae Johnston, 1865 (Annelida; Polychaeta). Sabecon Press Science Series 1:1-223.

Knox GA, Cameron DB. 1971. Port Phillip Bay Survey 1957-1963, Victoria, Australia. Part 2: Polychaeta. Memoirs of the National Museum of Victoria 32:21-42.

Kumar S, Stecher G, Li M, Knyaz C, Tamura K. 2018. MEGA X: Molecular Evolutionary Genetics Analysis across computing platforms. Molecular Biology and Evolution 35:1547-1549. 
1202 Lamarck JB. 1801. System of animals without vertebrae, or a general table of classes, orders 1203 and genera of these animals; Showing their essential characters and their distribution, after 1204 consideration of their natural relationships and their organization, and following the 1205 arrangement established in the galleries of the Museum of Natural History, among their 1206 preserved remains; Preceded by the opening speech of the Course of Zoology, given in the 1207 National Museum of Natural History year 8 of the Republic. Published by the author and 1208 Deterville, Paris: viii +432 pp.

1209 Lamarck JB. 1818. Histoire naturelle des Animaux sans Vertèbres, préséntant les caractères généraux et particuliers de ces animaux, leur distribution, leurs classes, leurs familles, leurs genres, et la citation des principales espèces qui s'y rapportent; precedes d'une Introduction offrant la determination des caracteres essentiels de l'Animal, sa distinction du vegetal et desautres corps naturels, enfin, l'Exposition des Principes fondamentaux de la Zoologie. Paris, Deterville. 5:612 pp.

Lewis C. 2005. Aspects of the reproductive biology of the South African polychaete, Arenicola loveni loveni (Kinberg 1866). Invertebrate Reproduction and Development 48(1-3):147-160.

Lewis C, Karageorgopoulos P. 2008. A new species of Marphysa (Eunicidae) from the western Cape of South Africa. Journal of the Marine Biological Association UK 88:277-287

Linnaeus C. 1758. Systema Naturae per regna tria naturae, secundum classes, ordines, genera, species, cum characteribus, differentiis, synonymis, locis. Editio decima, reformata [10th revised edition]. Laurentius Salvius Holmiae 1:824 pp

MacKenzie BL. 2005. An assessment of the shore baitfishery in the Eastern Cape. MSc thesis. Rhodes University, South Africa, 115 pp

Majiedt PA, Holness S, Sink KJ, Reed J, Franken M, van der Bank MG, Harris LR, Adams L, Perschke M, Miza SA, Currie J, Dunga LV. 2019. Chapter 4: Pressures on Marine Biodiversity. In: Sink KJ, van der Bank MG, Majiedt PA, Harris LR, Atkinson $\amalg$, Kirkman SP, Karenyi N (eds). 2019. South African National Biodiversity Assessment 2018 Technical Report Volume 4: Marine Realm. South African National Biodiversity Institute, Pretoria. South Africa. http://hdl.handle.net/20.500.12143/6372

1230 Marine Living Resources Act of 2014. Government Gazette, Volume 609, No. 39790. Available 1231 at www.gpwonline.co.za 
1232 McGrath MD, Horner CCM, Brouwer SL, Lamberth SJ, Mann BQ, Sauer WHH, Erasmus C. 1997.

1233 An economic valuation of the South African linefishery. South African Journal of Marine Science 1234 18(1):203-211.

1235 Mclntosh WC. 1885. Report on the Annelida Polychaeta collected by H.M.S. Challenger during 1236 the years $1873-76$. Report on the Scientific Results of the voyage of H.M.S. Challenger 1237 (Zoology) 12:1-554.

1238 Marenzeller E von. 1879. Südjapanische Anneliden. I. (Amphinomea, Aphroditea, Lycoridea, 1239 Phyllodocea, Hesionea, Syllidea, Eunicea, Glycerea, Sternaspidea, Chaetopterea, Cirratulea, 1240 Amphictenea.). Denkschriften der Kaiserlichen Akademie der Wissenschaften, Mathematisch1241 naturwissenschaftliche Classe, Wien. 41(2):109-154, plates I-VI.

1242 Montagu G. 1804. Description of several marine animals found on the south coast of 1243 Devonshire. Transactions of the Linnean Society, London 7:61-85, pl. 6-7.

1244 Montagu G. 1813. Descriptions of several new or rare animals, principally marine, discovered 1245 on the South coast of Devonshire. Transactions of the Linnean Society of London 11(1):1-26.

Moore JP. 1904. New Polychaeta from California. Proceedings of the Academy of Natural Sciences of Philadelphia 56:484-503, plates XXXVII-XXXVIII.

Moore JP. 1911. The polychaetous annelids dredged by the U.S.S. "Albatross" off the coast of Southern California in 1904. III. Euphrosynidae to Goniadidae. Proceedings of the Academy of Natural Sciences of Philadelphia. 63:234-318

Müller OF. 1776. Zoologiæ Danicæ Prodromus, seu Animalium Daniæ et Norvegiæ indigenarum characteres, nomina, et synonyma imprimis popularium. Havniæ [Copenhagen]:Hallageri. xxxii + $274 \mathrm{pp}$

Napier V R, Turpie JK, Clark BM. 2009. Value and management of the subsistence fishery at Knysna Estuary, South Africa. African Journal of Marine Science 31(3):297-310.

Nel P, Branch GM. 2014. The effect of bait collectors on stocks of Callichirus kraussi and Upogebia species in Langebaan Lagoon. African Zoology 49(1):30-43.

Onwuteaka J. 2016. Salinity induced longitudinal zonation of polychaete fauna on the Bonny River Estuary. Annual Research \& Review in Biology 10(2):1-14. 
1262 Paxton H. 1986. Generic revision and relationships of the family Onuphidae (Annelida:

1263 Polychaeta). Records of the Australian Museum 38(1):1-74.

1264 Pazoki S, Rahimian H, Struck TH, Katouzian AR, Kupriyanova EK. 2020. A new species of the

1265 Spirobranchus kraussii-complex (Annelida, Serpulidae) from the Persian Gulf and Gulf of Oman.

1266 Zootaxa 4748(3):401-430.

1267 Quatrefages A de. 1848. Études sur les types inférieurs de l'embranchements des annelés.

1268 Mémoire sur la famille des Hermelliens (Hermellea Nob.). Annales des Sciences Naturelles,

1269 Paris. Série 3. Zoologie 10:5-58, plate 2.

1270 Quatrefages A de. 1866. Histoire naturelle des Annelés marins et d'eau douce. Annélides et

1271 Géphyriens. Librarie Encyclopédique de Roret. Paris. 1:1-588

1272 Read G, Fauchald K. (Ed.) 2021. World Polychaeta database. Marphysa corallina (Kinberg,

1273 1865). Accessed at:

1274 http://www.marinespecies.org/polychaeta/aphia.php?p=taxdetails\&id=209831 on 2021-03-30

1275 Saayman M, Saayman A, Zeelie E, Potts W, Mann BQ, Weyl O, Van der Merwe P, Wood A,

1276 Raemeakers S, Cowley P, Pledger J, Bova C, Scholtz M. 2017. Economic significance of

1277 recreational angling in South Africa. Potchefstroom: Tourism Research in Economic Environs \&

1278 Society.

1279

Schmarda LK. 1861. Neue Wirbellose Thiere: Beobachted und Gesammelt auf einer Reise um die Erdr 1853 bis 1857. In Turbellarien, Rotatorien und Anneliden. Leipzig, Verlag von Wilhelm

1281 Engelmann. Erster Band, Zweite Hälfte, 164 pp.

Sowman M. 2006. Subsistence and small-scale fisheries in South Africa: A ten-year review. Marine Policy 30:60-73.

Sowman M, Sunde J, Raemaekers S, Schultz O. 2014. Fishing for equality: Policy for poverty alleviation for South Africa's small-scale fisheries. Marine Policy 46:31-42.

Simon CA, du Toit AN, Smith MKS, Claassens L, Smith F \& Smith P. 2019a. Bait collecting by subsistence and recreational fishers in Knysna Estuary may impact management and conservation, African Zoology 54(2):91-103, DOI: 10.1080/15627020.2019.1608862 42. 
1292 Simon CA, Kara J, Naidoo C, Matthee CA. 2020. Genetic structure of bloodworm, Arenicola

1293 loveni (Annelida; Arenicolidae) suggests risk of local extinction in the face of overexploitation is 1294 lower than expected. African Zoology 55(2):175-183,

1295 https://doi.org/10.1080/15627020.2020.1723440

1296 Smith F, Smith P. 2012. A brief field guide to the common shore creatures of the Knysna 1297 estuary. The Knysna Basin Project, Knysna, South Africa. ISBN 978099217590-0

1298 Spengel JW. 1912. Einige Organisationsverhaltnisse von Sipunculusarten und ihre Bedeutung 1299 fur die Systematik dieser Tiere. Deutsch. Zool. Ges. 22:261-272.

1300

1301

1302

1303

1304

1305

1306

1307

1308

1309

1310

1311

1312

1313

1314

1315

1316

1317

1318

1319

1320

1321

Stair JB. 1847. An account of Palolo, a sea-worm eaten in the Navigator Islands, with a description by JE Gray. Proceedings of the Zoological Society of London, 15:17-18.

Stephen AC. 1942. The South African intertidal zone and its relation to ocean currents: Notes on the intertidal sipunculids of Cape Province and Natal. Annals of the Natal Museum 10(2):245-256

Stephen AC. 1964. A revision of the classification of the phylum Sipuncula. Annals and Magazine of Natural History 7:457-462.

Teske PR, Von der Heyden S, McQuaid CD, Barker NP. 2011. A review of marine phylogeography in southern Africa. South African Journal of Science 107(5/6):1-11.

Turpie JK, Heydenrych BJ, Lamberth SJ. 2003. Economic value of terrestrial and marine biodiversity in the Cape Floristic Region: implications for defining effective and socially optimal conservation strategies. Biological Conservation 112:233-251.

van Der Westhuizen HC, Marais JFK. 1977. Stomach content analyses of Pomadasys commersonni from the Swartkops Estuary (Pisces: Pomadasyidae). Zoologica Africana 12:500504.

van Herwerden L. 1989. Collection of musselworms Pseudonereis variegata for bait - a legislative anachronism. South African Journal of Marine Science 8:363-366.

van Herwerden L, Griffiths CL, Bally R, Blaine M, du Plessis C.. 1989. Patterns of shore utilization in a metropolitan area: the Cape Peninsula, South Africa. Ocean \& Shoreline Management 12: 331-346.

van Rensburg H. 2019. Taxonomy and Distribution of Moonshine Worms (Diopatra sp.) in Knysna Estuary. Unpublished MSc thesis, Stellenbosch University, South Africa. 
1322

1323

1324

1325

1326

1327

1328

1329

1330

1331

1332

1333

1334

1335

1336

1337

1338

1339

1340

1341

1342

1343

1344

1345

1346

1347

van Rensburg H, Matthee CA, Simon CA. 2020. Moonshineworms (Diopatra aciculata:

Onuphidae, Annelida) in the Knysna Estuary, South Africa; taxonomy and distribution. Journal of the Marine Biological Association of the United Kingdom 100(6):897-907.

https://doi.org/10.1017/S0025315420000740

Villalobos-Guerrero TF. 2019. Redescription of two overlooked species of the Perinereis nuntia complex and morphological delimitation of P. nuntia (Savigny in Lamarck, 1818) from the Red Sea (Annelida, Nereididae). Zoosystema 41(24):465-496.

Von Marenzeller E. 1888. Polychäten der Angra Pequena-Bucht. Zoologische Jahrbücher, Abteilung für Systematik, Geographie und Biologie der Tiere 3(1):1-24.

Watson GJ, Murray JM, Schaefer, Bonner A. 2017. Bait worms: a valuable and important fishery with implications for fisheries and conservation management. Fish and Fisheries 18(2):374-388

Wells G P. 1959. The genera of Arenicolidae (Polychaeta). Proceedings of the Zoological Society of London. 133(2):301-314

Wells G P. 1963. The lugworms of the southern cold temperate zone (Arenicolidae, Polychaeta). Proceedings of the Zoological Society of London 140(1):121-159.

Willey A. 1904. Littoral Polychaeta from the Cape of Good Hope. Transactions of the Linnean Society of London, Series 2, Zoology 9(6):255-268.

Wilson RS, Glasby CJ. 1993. A revision of the Perinereis nuntia species group (Polychaeta: Nereididae). Records of the Australian Museum 45(3):253-277.

Wooldridge TH, Coetzee PS. 1998. Marine invertebrates, Chapter 7, pp 117-134. In: Lubke R \& de Moor I, ed. Field guide to the Eastern and Southern cape coasts. University of Cape Town Press, Cape Town.

Zhou H, Zhang Z, Chen H, Sun R, Wang H, Huo L, Pan H. 2010. Integrating a DNA barcoding project with an ecological survey: a case study on temperate intertidal polychaetes communities in Qingdao, China. Chinese journal of Oceanology and Limnology 28(4):899-910. 


\section{Table $\mathbf{1}$ (on next page)}

Museum and GenBank accession numbers with location and collector details

Table 1: Museum and GenBank accession numbers with location and collector details. GenBank accession numbers may be repeated when haplotypes are shared among different individuals. Samples were received from contributing fishermen and processed by Alheit du Toit (AdT), Caveshlin Naidoo (CN), Carol Simon (CS), and Hendré van Rensburg (HvR). NS - no sequences. \# Sequences were previously published in Simon et al. (2020). 
Table 1: Baitworm species from Western Cape, South Africa, found in this study, including common names, locations, collector details. GenBank accession numbers may be repeated when haplotypes are shared among different individuals. Samples were received from contributing fishermen and processed by Alheit du Toit (AdT), Caveshlin Naidoo (CN), Carol Simon (CS), Ethan Newman (EN) and Hendré van Rensburg (HvR). NS - no sequences. \# Sequences were previously published in Simon et al. (2020).

\begin{tabular}{|c|c|c|c|c|c|c|c|}
\hline Species name & $\begin{array}{l}\text { Common name } \\
\text { according to } \\
\text { fisherman\$ }\end{array}$ & Location & $\begin{array}{l}\text { Fisherman's } \\
\text { name }\end{array}$ & $\begin{array}{l}\text { Type of Bait } \\
\text { Collector }\end{array}$ & $\begin{array}{l}\text { Collector } \\
\text { and sample } \\
\text { processor }\end{array}$ & $\begin{array}{l}\text { GenBank } \\
\text { Accession } \\
\text { Number (COI) } \\
\text { (Number of } \\
\text { individuals) }\end{array}$ & $\begin{array}{l}\text { Museum Accession Number } \\
\text { (number of individuals) }\end{array}$ \\
\hline \multirow[t]{2}{*}{ Siphonosoma dayi } & Sand worm & Knysna Estuary & Gerrie Barnard & Recreational & AdT & MW598440 & MB-A090313 \\
\hline & Sand worm & Knysna Estuary & Gerrie Barnard & Recreational & AdT & MW598441 & MB-A090318 \\
\hline \multirow[t]{5}{*}{ Abarenicola gilchristi } & Bloodworm & Betty's Bay & Ethan Newman & Recreational & EN \& CS & NS & $\begin{array}{l}\text { MB-A090223 - MB-A090226 } \\
\text { (4) }\end{array}$ \\
\hline & Bakkiewurm & Pearly Beach & Frans & Recreational & $\mathrm{CN} \& \mathrm{AdT}$ & MW595992 & MB-A090249 \\
\hline & Bakkiewurm & Pearly Beach & Frans & Recreational & $\mathrm{CN} \& \mathrm{AdT}$ & MW595993 & DNA only \\
\hline & Bakkiewurm & Pearly Beach & Frans & Recreational & $\mathrm{CN} \& \mathrm{AdT}$ & MW595994 & DNA only \\
\hline & Bakkiewurm & Pearly Beach & Frans & Recreational & CN \& AdT & MW595995 & DNA only \\
\hline \multirow[t]{14}{*}{ Arenicola lovenï } & Bloodworm & Betty's Bay & Morne \& Victor & Recreational & AdT & MK922184 & MB-A090220 \\
\hline & Bloodworm & Betty's Bay & Morne \& Victor & Recreational & AdT & MK922185 & MB-A090221 \\
\hline & Bloodworm & Betty's Bay & Morne \& Victor & Recreational & AdT & MK922163 & MB-A090222 \\
\hline & Blood worm & Knysna Estuary & Gerrie Barnard & Recreational & AdT & MK922157 & MB-A090231 \\
\hline & Blood worm & Knysna Estuary & Gerrie Barnard & Recreational & AdT & MK922158 & MB-A090232 \\
\hline & Blood worm & Knysna Estuary & Gerrie Barnard & Recreational & AdT & MK922159 & MB-A090233 \\
\hline & Blood worm & Knysna Estuary & Dewald Kamp & Recreational & AdT & MK922160 & MB-A090234 \\
\hline & Blood worm & Knysna Estuary & Dewald Kamp & Recreational & AdT & MK922161 & MB-A090235 \\
\hline & Blood worm & Knysna Estuary & Albert Kapp & Recreational & AdT & MK922158 & MB-A090236, MB-A090237 \\
\hline & Bloodworm & Muizenberg & Anonymous & Recreational & $\mathrm{AdT} \& \mathrm{CN}$ & MK922158 & MB-A090227, MB-A090229 \\
\hline & Bloodworm & Muizenberg & Anonymous & Recreational & $\mathrm{AdT} \& \mathrm{CN}$ & MK922164 & MB-A090228 \\
\hline & Bloodworm & Muizenberg & Anonymous & Recreational & AdT & NS & MB-A090230 \\
\hline & Bloodworm & Muizenberg & Anonymous & Recreational & AdT \& CN & NS & MB-A090374 \\
\hline & Bloodworm & Pearly Beach & Ferdi Joubert & Recreational & AdT \& HvR & MK922163 & MB-A090246, MB-A090247 \\
\hline
\end{tabular}




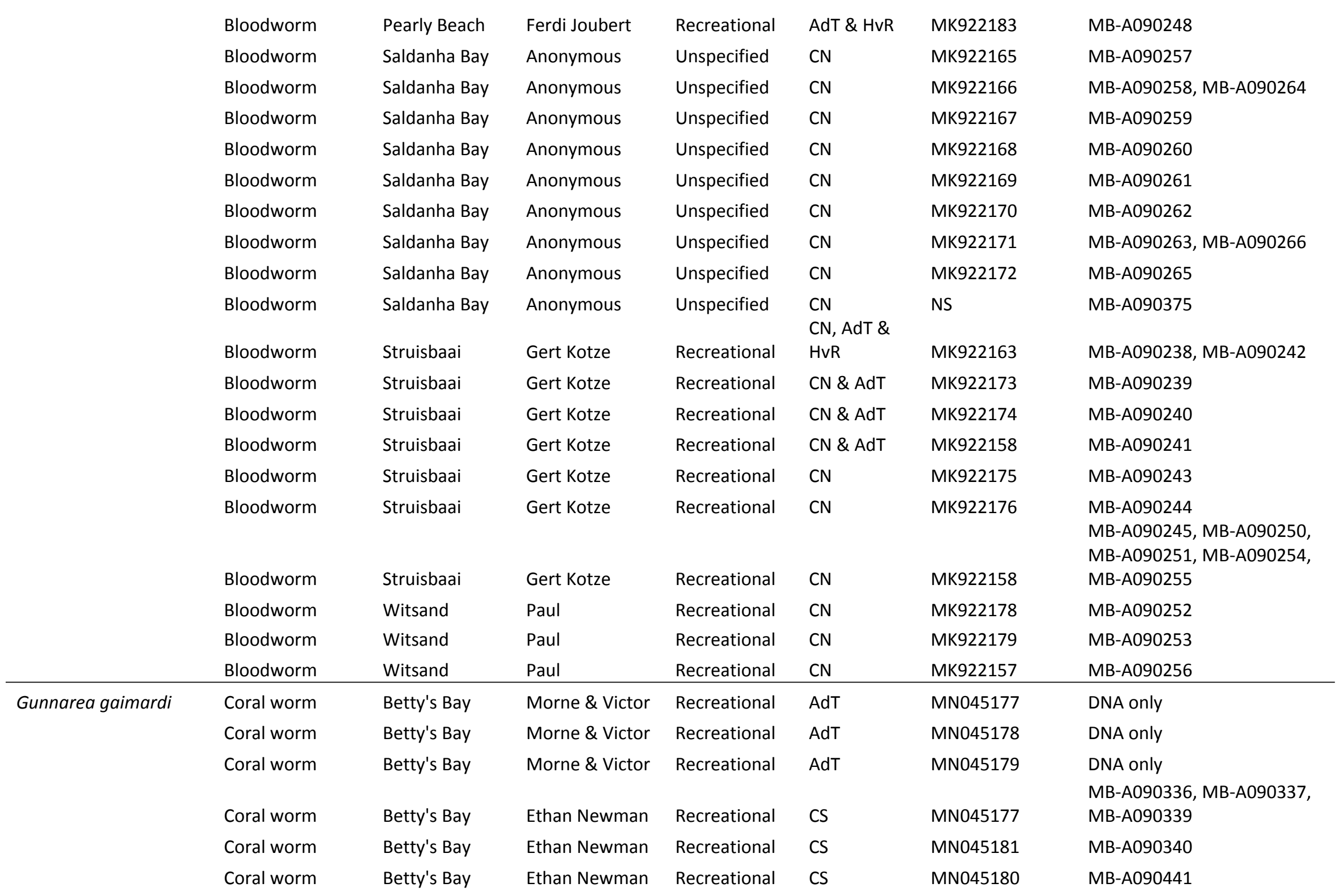




\begin{tabular}{|c|c|c|c|c|c|c|c|}
\hline & Polwurm & Hermanus & $\begin{array}{l}\text { Hein } \\
\text { Engelbrecht } \\
\text { Hein }\end{array}$ & Recreational & AdT \& HvR & MN045177 & $\begin{array}{l}\text { MB-A090344, MB-A090345, } \\
\text { MB-A090347, MB-A090348 }\end{array}$ \\
\hline & Polwurm & Hermanus & $\begin{array}{l}\text { Engelbrecht } \\
\text { Hein }\end{array}$ & Recreational & AdT \& HvR & NS & MB-A090343 \\
\hline & Polwurm & Hermanus & Engelbrecht & Recreational & AdT \& HvR & MN045182 & MB-A090346 \\
\hline & Coral worm & Velddrif & Anonymous & Subsistence & AdT & MN045177 & $\begin{array}{l}\text { MB-A090356 - MB-A090358, } \\
\text { MB-A090364, MB-A090367- } \\
\text { MB-A090371 (9) }\end{array}$ \\
\hline & Coral worm & Velddrif & Anonymous & Subsistence & AdT & MN045179 & MB-A090360 \\
\hline \multirow[t]{2}{*}{ Gunnarea sp.1 } & Coral worm & Witsand & Paul & Recreational & AdT & MN045184 & MB-A090293 \\
\hline & Coral worm & Witsand & Paul & Recreational & AdT & MN045183 & MB-A090294 \\
\hline $\begin{array}{l}\text { Scoletoma cf. tetraura } \\
\text { sp. } 1 \text { (Betty's Bay) }\end{array}$ & Pudding worm & Betty's Bay & Ethan Newman & Recreational & CS & MN419154 & MB-A090332 \\
\hline \multirow[t]{6}{*}{$\begin{array}{l}\text { Scoletoma cf. tetraura } \\
\text { sp. } 2 \text { (Hermanus) }\end{array}$} & Pudding worm & Hermanus & $\begin{array}{l}\text { Hein } \\
\text { Engelbrecht } \\
\text { Hein }\end{array}$ & Recreational & AdT \& HvR & NS & MB-A090349 \\
\hline & Pudding worm & Hermanus & $\begin{array}{l}\text { Engelbrecht } \\
\text { Hein }\end{array}$ & Recreational & AdT \& HvR & MN419157 & MB-A090350 \\
\hline & Pudding worm & Hermanus & $\begin{array}{l}\text { Engelbrecht } \\
\text { Hein }\end{array}$ & Recreational & AdT \& HvR & NS & MB-A090351 \\
\hline & Pudding worm & Hermanus & $\begin{array}{l}\text { Engelbrecht } \\
\text { Hein }\end{array}$ & Recreational & AdT \& HvR & NS & MB-A090352 \\
\hline & Pudding worm & Hermanus & $\begin{array}{l}\text { Engelbrecht } \\
\text { Hein }\end{array}$ & Recreational & AdT \& HvR & MN419156 & MB-A090353 \\
\hline & Pudding worm & Hermanus & Engelbrecht & Recreational & AdT \& HvR & MN419155 & MB-A090354 \\
\hline \multirow[t]{2}{*}{ Marphysa corallina } & Wonderworm & Witsand & Paul & Recreational & AdT & MN067881 & $\begin{array}{l}\text { MB-A090276 - MB-A090278, } \\
\text { MB-A090280 (4) }\end{array}$ \\
\hline & Wonderworm & Witsand & Paul & Recreational & AdT & MN067882 & MB-A090279 \\
\hline \multirow[t]{2}{*}{ Marphysa haemasoma } & Wonderworm & Betty's Bay & Ethan Newman & Recreational & CS & NS & MB-A090331 \\
\hline & Wonderworm & Betty's Bay & Ethan Newman & Recreational & CS & MN067877 & $\begin{array}{l}\text { MB-A090333, MB-A090335, } \\
\text { MB-A090338 (3) }\end{array}$ \\
\hline
\end{tabular}




\begin{tabular}{|c|c|c|c|c|c|c|c|}
\hline & Wonderworm & Betty's Bay & Ethan Newman & Recreational & CS & NS & MB-A090334 \\
\hline & Wonderworm & Knysna Estuary & Anonymous & Recreational & AdT & MN067879 (3) & DNA only \\
\hline & Wonderworm & Knysna Estuary & Anonymous & Recreational & AdT & MN067878 (2) & $\begin{array}{l}\text { DNA only } \\
\text { MB-A090326, MB-A090328 }\end{array}$ \\
\hline & Bloukoppie & $\begin{array}{l}\text { Knysna Estuary } \\
\text { Melkbos }\end{array}$ & Anonymous & Subsistence & AdT & MN067878 & $(2)$ \\
\hline & Bloodworm & $\begin{array}{l}\text { Strand } \\
\text { Melkbos }\end{array}$ & Lucas & Subsistence & AdT \& CN & MN067877 (2) & $\begin{array}{l}\text { DNA only } \\
\text { MB-A090267 - MB-A090270 }\end{array}$ \\
\hline & Bloodworm & $\begin{array}{l}\text { Strand } \\
\text { Soetwater }\end{array}$ & Lucas & Subsistence & AdT \& CN & MN067877 & (4) \\
\hline & Wonderworm & $\begin{array}{l}\text { Kommetjie } \\
\text { Soetwater }\end{array}$ & Altus & Subsistence & AdT & MN067877 & DNA only \\
\hline & Wonderworm & Kommetjie & Altus & Subsistence & AdT & NS & MB-A090272 \\
\hline & Wonderworm & $\begin{array}{l}\text { Soetwater } \\
\text { Kommetjie }\end{array}$ & Altus & Subsistence & AdT & MN067877 & $\begin{array}{l}\text { MB-A090273 - MB-A090275, } \\
\text { MB-A090317 (4) }\end{array}$ \\
\hline & $\begin{array}{l}\text { Wonderworm } \\
\text { Wonderworm }\end{array}$ & Strand & Marnus & $\begin{array}{l}\text { Subsistence } \\
\text { Subsistence }\end{array}$ & $\begin{array}{l}\text { AdT \& HvR } \\
\text { AdT \& HvR }\end{array}$ & $\begin{array}{l}\text { MN067880 } \\
\text { MN067880 }\end{array}$ & $\begin{array}{l}\text { DNA only } \\
\text { MB-A090271, MB-A090315 } \\
\text { (2) }\end{array}$ \\
\hline Lysidice natalensis & Musselworm & Witsand & Paul & Recreational & AdT & MN419162 & MB-A090281 \\
\hline & Musselworm & Witsand & Paul & Recreational & AdT & MN419168 & $\begin{array}{l}\text { MB-A090282 } \\
\text { MB-A090283, MB-A090285 }\end{array}$ \\
\hline & Musselworm & Witsand & Paul & Recreational & AdT & MN419165 & $(2)$ \\
\hline & Musselworm & Witsand & Paul & Recreational & AdT & MN419164 & MB-A090284 \\
\hline & Musselworm & Witsand & Paul & Recreational & AdT & MN419160 & MB-A090286 \\
\hline & Musselworm & Witsand & Paul & Recreational & AdT & MN419161 & MB-A090287 \\
\hline & Musselworm & Witsand & Paul & Recreational & AdT & MN419158 & MB-A090288 \\
\hline & Musselworm & Witsand & Paul & Recreational & AdT & MN419159 & MB-A090289 \\
\hline & Musselworm & Witsand & Paul & Recreational & AdT & MN419167 & MB-A090291 \\
\hline & Musselworm & Witsand & Paul & Recreational & AdT & MN419163 & MB-A090292 \\
\hline $\begin{array}{l}\text { Heptaceras } \\
\text { quinuedens }\end{array}$ & Moonshineworm & Pearly Beach & $\begin{array}{l}\text { Ferdi Joubert } \\
\text { Hermann } \\
\text { Schuch \& }\end{array}$ & Recreational & AdT \& HvR & NS & $\begin{array}{l}\text { MB-A090432 - MB-A090436 } \\
\text { (5) }\end{array}$ \\
\hline & Moonshineworm & Strand & Charlie Friess & Recreational & AdT \& HvR & NS & MB-A090442 \\
\hline
\end{tabular}




\begin{tabular}{|c|c|c|c|c|c|c|c|}
\hline & Moonshineworm & Struisbaai & Gert Kotze & Recreational & $\begin{array}{l}\mathrm{CN}, \mathrm{AdT} \& \\
\mathrm{HvR}\end{array}$ & NS & $\begin{array}{l}\text { MB-A090421 - MB-A090431, } \\
\text { MB-A090437 - MB-A090440 } \\
\text { (15) }\end{array}$ \\
\hline Perinereis latipalpa & Coral worm & Kommetjie & Mario & Subsistence & AdT & NS & $\begin{array}{l}\text { MB-A090297 - MB-A090299 } \\
\text { (3) }\end{array}$ \\
\hline \multirow[t]{11}{*}{ Pseudonereis podocirra } & Musselworm & Betty's Bay & Morne \& Victor & Recreational & AdT & MN067871 & $\begin{array}{l}\text { MB-A090302, MB-A090305 } \\
\text { (2) }\end{array}$ \\
\hline & Musselworm & Betty's Bay & $\begin{array}{l}\text { Morne \& Victor } \\
\text { Hein }\end{array}$ & Recreational & AdT & MN067870 & MB-A090304 \\
\hline & Musselworm & Hermanus & $\begin{array}{l}\text { Engelbrecht } \\
\text { Hein }\end{array}$ & Recreational & AdT \& HvR & MN067872 & MB-A090306 \\
\hline & Musselworm & Hermanus & Engelbrecht & Recreational & AdT \& HvR & MN067873 & MB-A090307 \\
\hline & Musselworm & Hermanus & $\begin{array}{l}\text { Hein } \\
\text { Engelbrecht } \\
\text { Hein }\end{array}$ & Recreational & AdT \& HvR & MN067871 & $\begin{array}{l}\text { MB-A090308, MB-A090309, } \\
\text { MB-A090443 }\end{array}$ \\
\hline & Musselworm & Hermanus & Engelbrecht & Recreational & AdT \& HvR & MN067872 & $\begin{array}{l}\text { MB-A090310 } \\
\text { MB-A090355, MB-A090362, } \\
\text { MB-A090363, MB-A090365 }\end{array}$ \\
\hline & Coral worm & Velddrif & Anonymous & Subsistence & AdT & MN067874 & $\begin{array}{l}\text { (4) } \\
\text { MB-A090359, MB-A090361 }\end{array}$ \\
\hline & Coral worm & Velddrif & Anonymous & Subsistence & AdT & MN067871 & (2) \\
\hline & Coral worm & Velddrif & Anonymous & Subsistence & AdT & MN067872 & MB-A090366 \\
\hline & Coral worm & Velddrif & Anonymous & Subsistence & AdT & MN067875 & MB-A090372 \\
\hline & Coral worm & Velddrif & Anonymous & Subsistence & AdT & MN067876 & MB-A090373 \\
\hline
\end{tabular}

\$ The English names are listed, although fishermen frequently use Afrikaans translations: bloodworm (bloedwurm), Coral worm (koraalwurm), mussel worm (mosselwurm), moonshine worm (maanskynwurm), pudding worm (poedingwurm), wonderworm (wonderwurm). English names were never used for polwurm or bakkiewurm. 
Figure 1

Map of South Africa and the Western Cape province with sample sites.

Figure 1. Sample sites in the Western Cape Province, South Africa: Velddrif, Saldanha Bay, Melkbosstrand, Kommetjie (Soetwater), Muizenberg, Strand, Betty's Bay, Hermanus, Pearly Beach, Struisbaai, Witsand, Knysna, with the two main barriers to gene flow in the Western Cape Province, and three main ecoregions along the South African coast. (Map created in http://www.simplemappr.net/ and edited in Photoshop Version C6.)

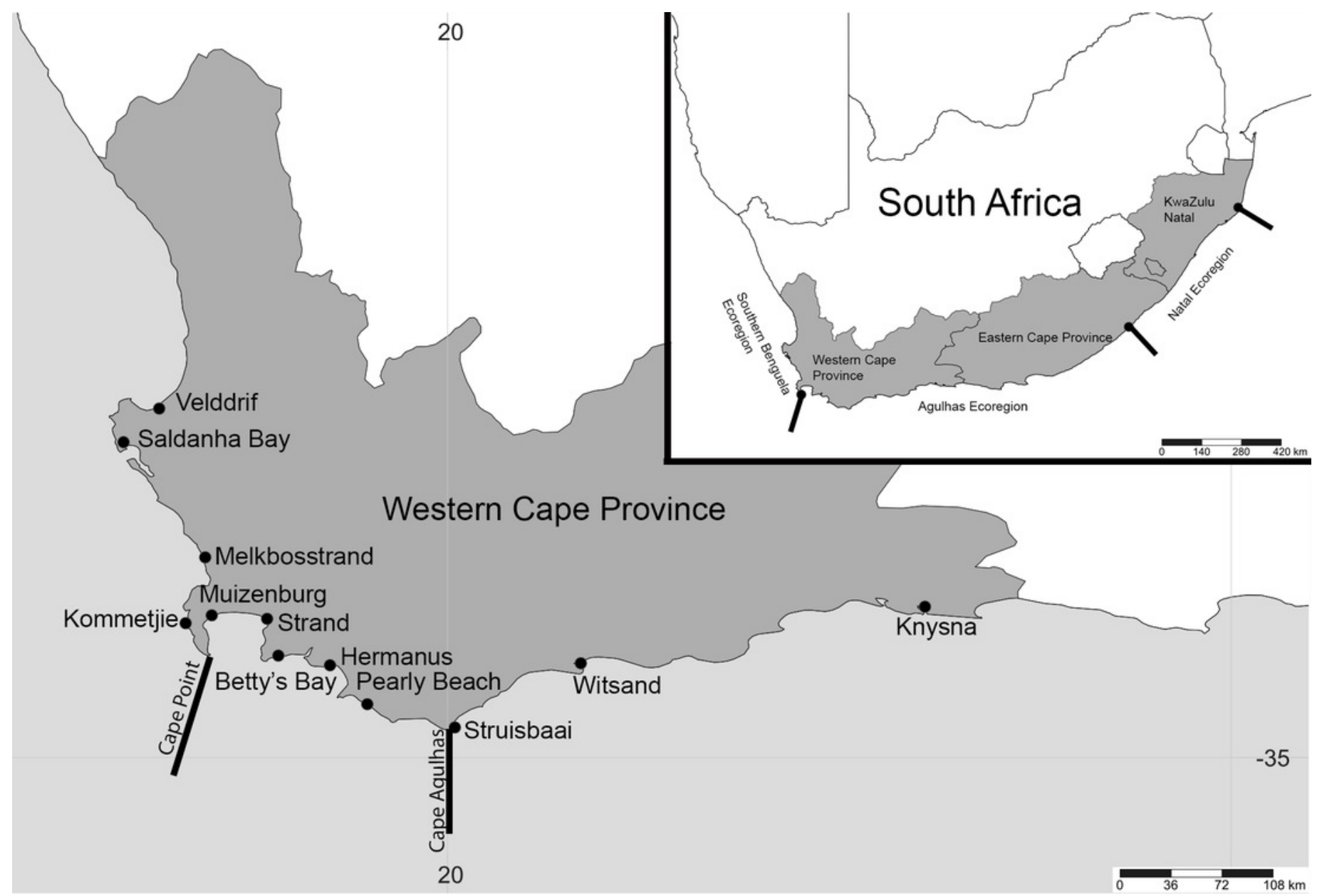




\section{Figure 2}

Morphology of Siphonosoma dayi

Figure 2. Siphonosoma dayi Stephen, 1942. A) Fixed specimen, in two pieces, B) Everted introvert with tentacles, C) Scales on anterior of introvert, D) scales on posterior of introvert, E) Anterior, internal structure showing insertions of introvert muscles (white arrowheads), bands of longitudinal muscles (black arrows), anastomosed sheet of muscle in anterior (black arrowhead) and rectum (*), F) Pair of nephridia (N) and broken rectum $(*)$ with insertion of anus (white arrowhead), G) Magnification of digestive system showing insertions of introvert muscles (arrowheads) and bands of longitudinal muscle (black arrow), H) Close-up of insertion of dorsal introvert muscle (white arrowhead) and spindle muscle (black arrowhead). Scale Bars: $A=10 \mathrm{~mm} ; B, H=2.5 \mathrm{~mm} ; C=0.5 \mathrm{~mm}, D=1 \mathrm{~mm} ; E, F, G=5 \mathrm{~mm} ; A B-D=M B$ A090318; $E-H=M B A 090313$ 


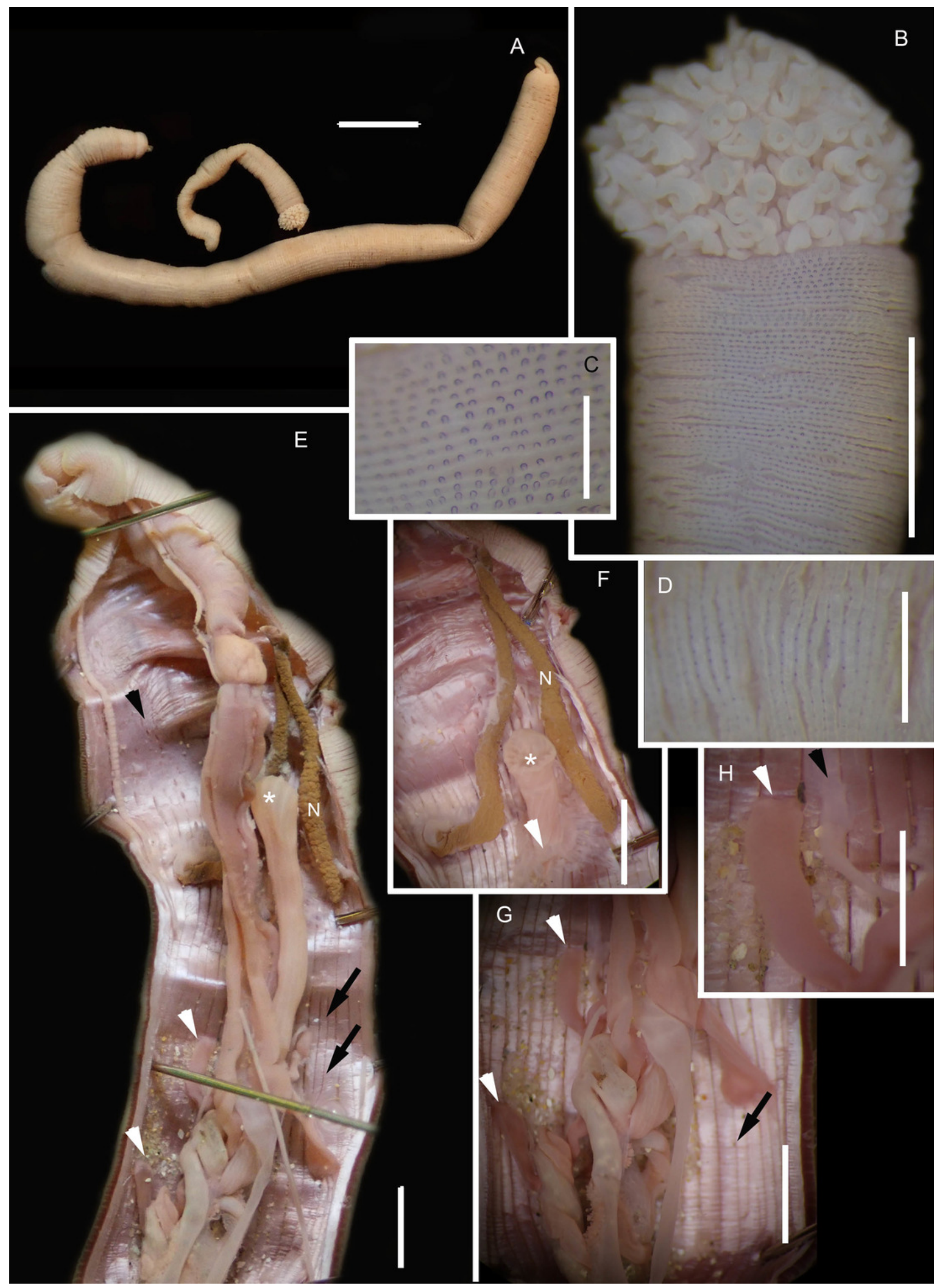




\section{Figure 3}

Neighbour Joining tree of Siphonosoma species

Figure 3. Neighbour Joining tree using mitochondrial sequences of various Siphonosoma Spengel, 1912 species, including S. dayi Stephen, 1942 from Knysna. * Indicates bootstrap support greater than or equal to $80 \%$. Sequences obtained in this study are highlighted in grey. Urechis caupo Fisher \& MacGinite, 1928 was used as the outgroup. Scale bar represents number of substitutions per site. 


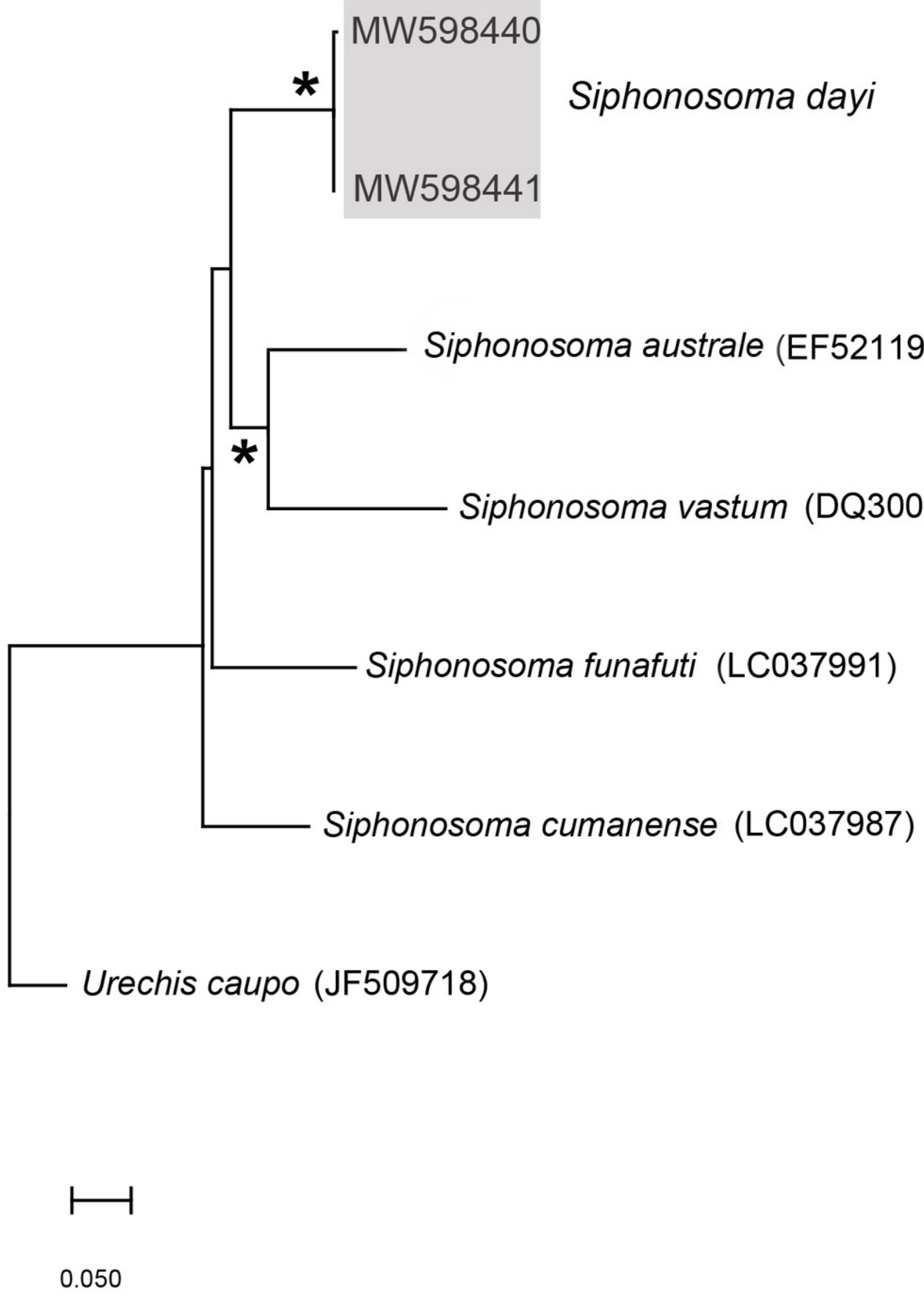




\section{Figure 4}

External morphology of Arenicola loveni

Figure 4. Arenicola loveni Kinberg, 1866. A) Almost uniformly dark specimen from

Muizenberg, dorsal view, B) Dark specimen with distinctly lighter tail from Struisbaai, lateral view, C) Close-up of proboscis of specimen in (B) showing annuli (white arrowheads), D) Light brown specimen with distinctly lighter branchial and tail region from Muizenberg, showing annuli in anterior chaetigers (white arrowheads), dorsal view, E) Prostomium and partially everted proboscis, dorsal view, arrows show nuchal grooves, F) Proboscis showing papillae in different regions, dorsal view, G) Papillae of distal part of proboscis, dorsal view, H) Papillae of proximal part of proboscis, dorsal view. Scale bars: $A, B, D=2 \mathrm{~cm}, C, E, F=5 \mathrm{~mm}, \mathrm{G}, \mathrm{H}=$ $2.5 \mathrm{~mm} . \mathrm{A}=\mathrm{MB}-\mathrm{A} 090229, \mathrm{~B}=\mathrm{MB}-\mathrm{A} 090241, \mathrm{D}=\mathrm{MB}-\mathrm{A} 090227, \mathrm{E}-\mathrm{H}: \mathrm{MB}-\mathrm{A} 090259$ 

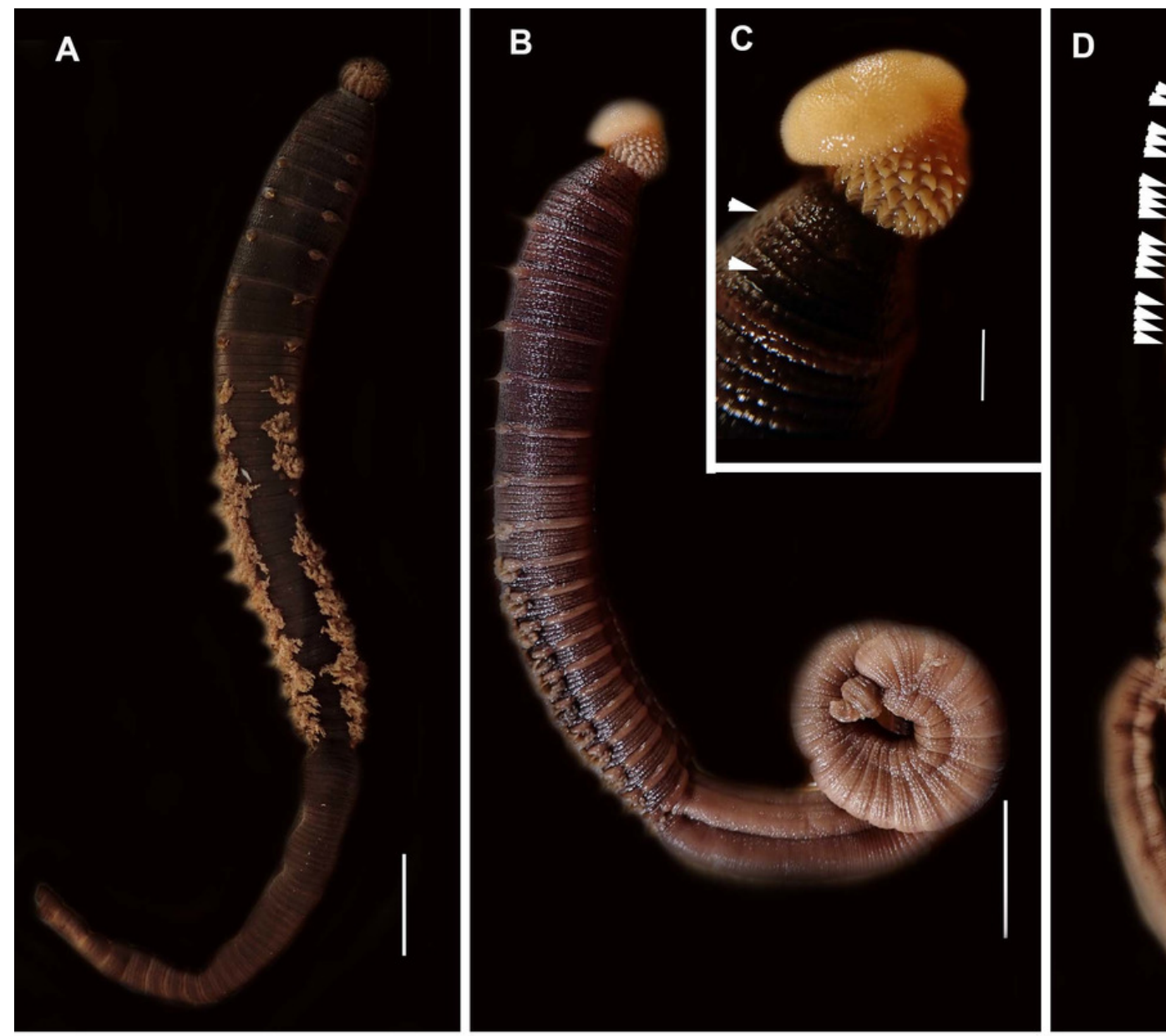

E
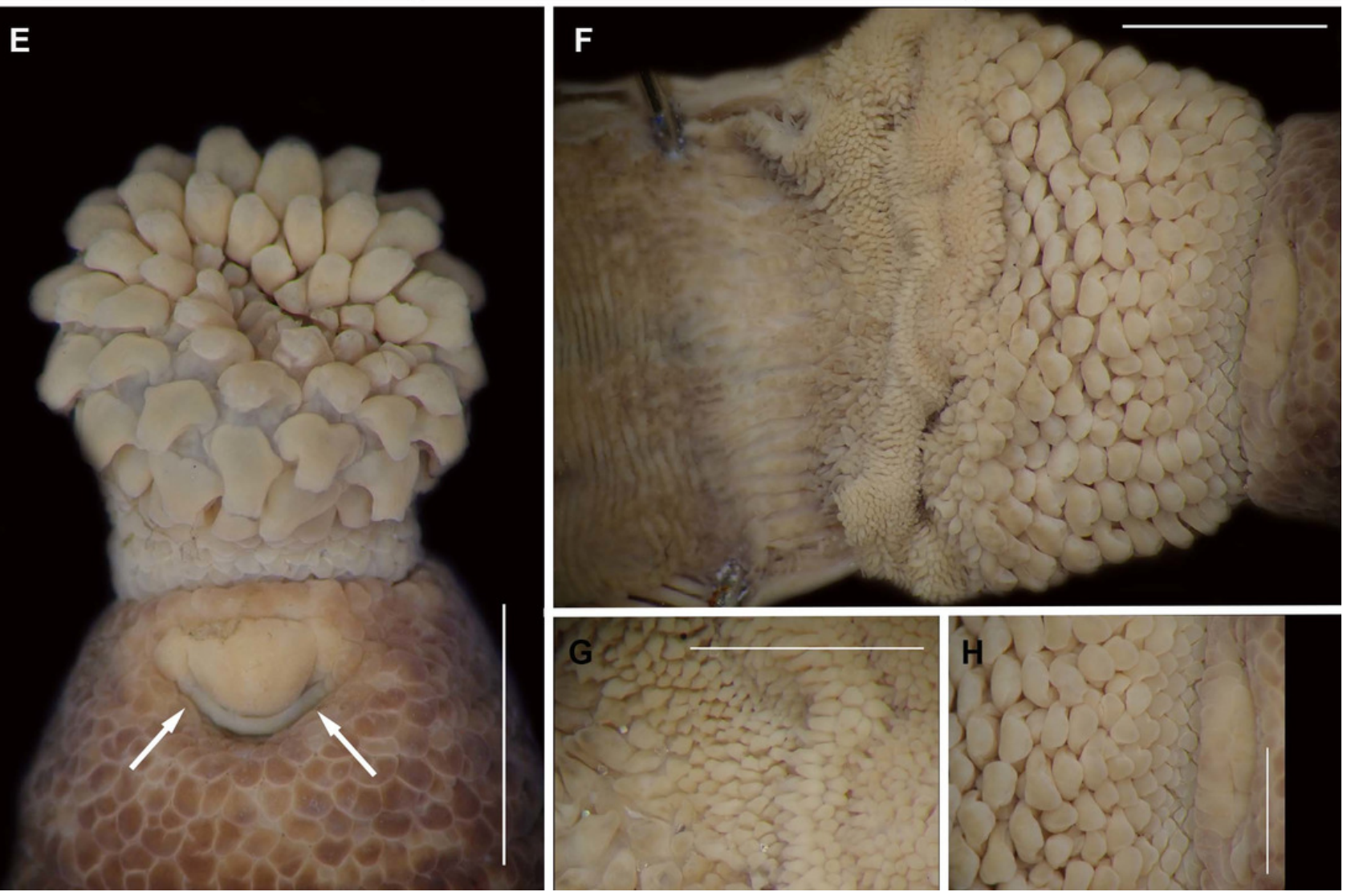

Peerj reviewing PDF | (2021:04:59876:2:0:NEW 28 Jun 2021) 


\section{Figure 5}

Morphology of Arenicola loveni

Figure 5. Arenicola loveni Kinberg, 1866. A) Dorsal view of digestive system with septal pouches (arrowhead) and single pair of oesophageal caecae (arrow), B) Close up of anterior digestive system (ventral view) and septal pouches (arrowhead) and partially everted proboscis, C) Hooded nephridiopore, D) Partially hooded nephridiopore, E) Chaetiger 7 with vestigial branchia (arrowhead), F) Fully formed branchiae on chaetiger 14, G) Close up of palmar membrane showing papillated surface. Scale bars: $A, B,=10 \mathrm{~mm}, C, G=1.5 \mathrm{~mm}, \mathrm{D}$ $F=2.5 m m, A: M B-A 090252, B, D: M B-A 090250, C, E-G: M B-A 090259$. 


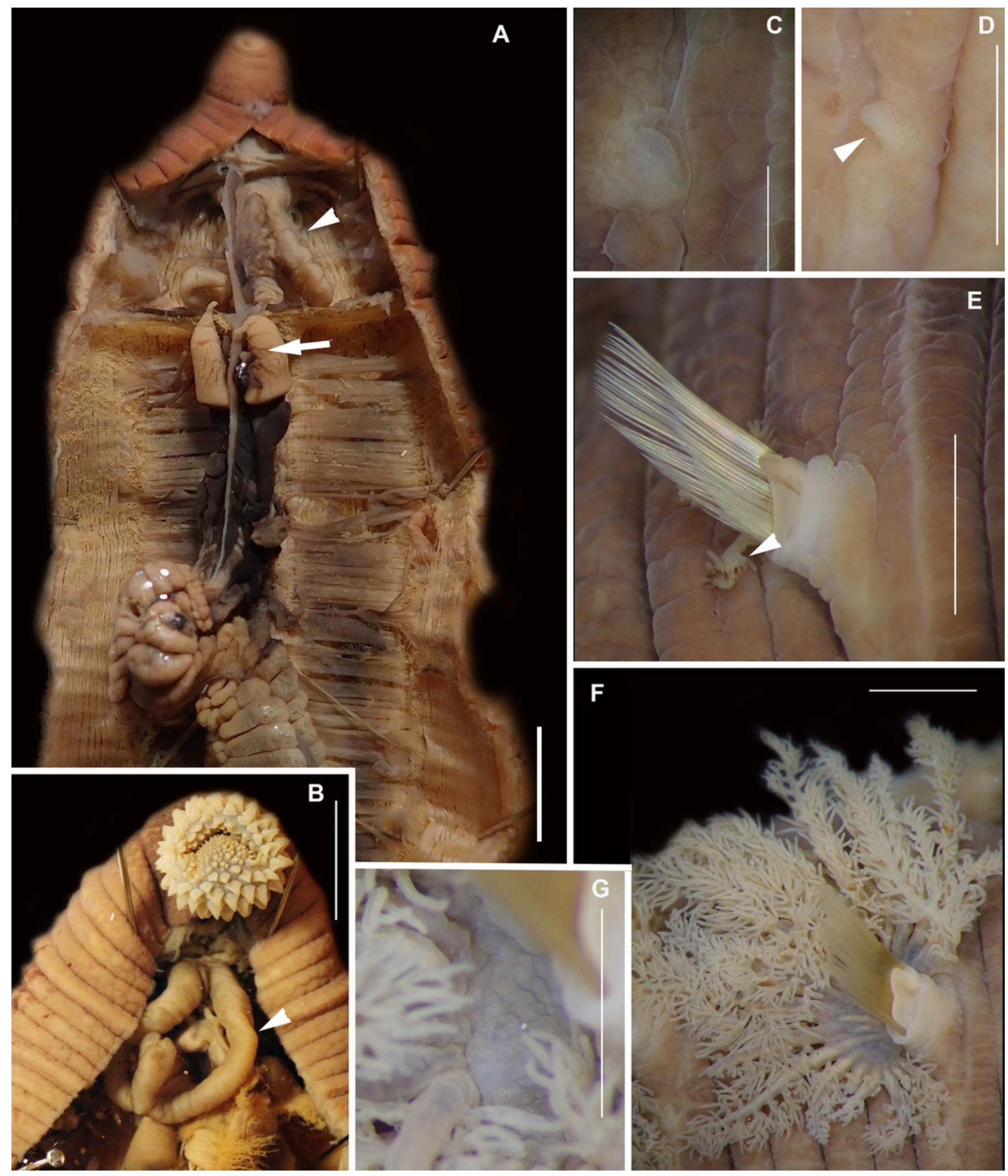




\section{Figure 6}

\section{Arenicolid chatae}

Figure 6. Arenicolid chaetae. A) Notochaetae and B) Neuropodial hooks of Arenicola loveni Kinberg, 1866, C) Notochaetae and D) Neuropodial hooks of Abarenicola gilchristi Wells, 1963. Scale Bars: A - D =0.1mm. A, B = MB-A090261, C, D = MB-A090225
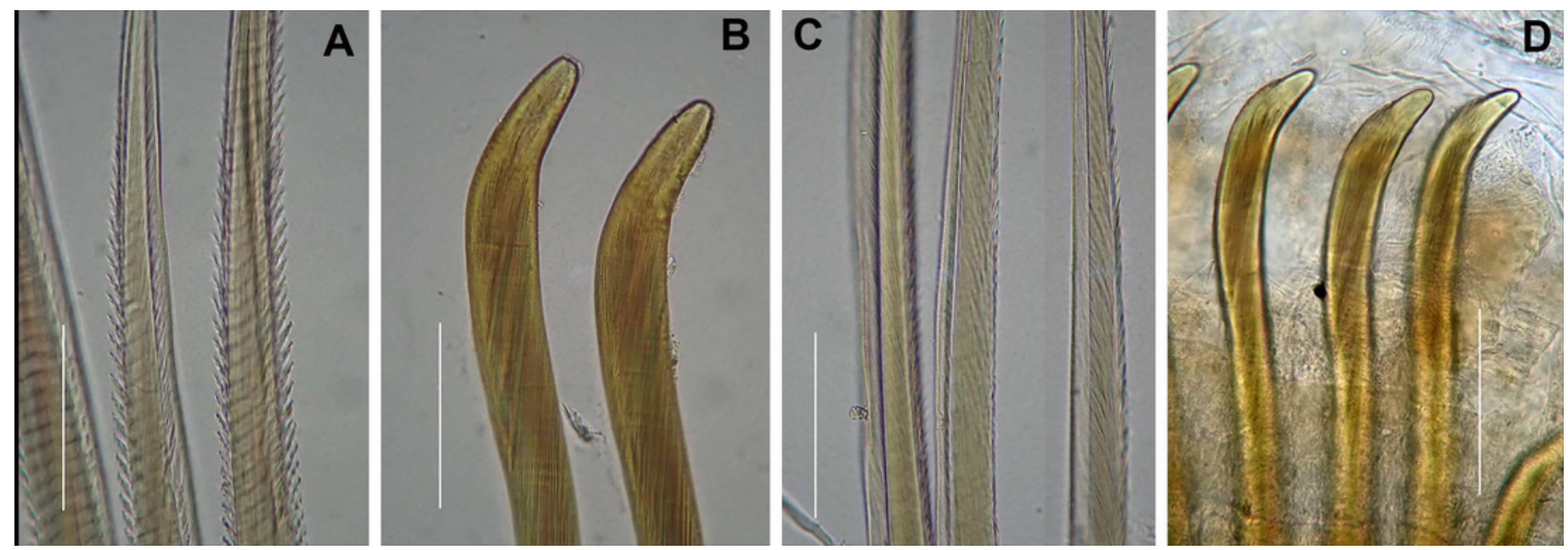


\section{Figure 7}

Neighbour joining tree of Arenicolidae

Figure 7. Neighbour Joining tree using mitochondrial sequences belonging to various Arenicola Lamarck, 1801 and Abarenicola Wells, 1959 species, including A. loveni Kinberg, 1866 and A. gilchristi Wells, 1963 from South Africa. * Indicates bootstrap support greater than or equal to $80 \%$. Areas highlighted in grey represent sequences generated in this study. Maldanidae sp. was used as outgroup. Scale bar represents substitutions per site. 


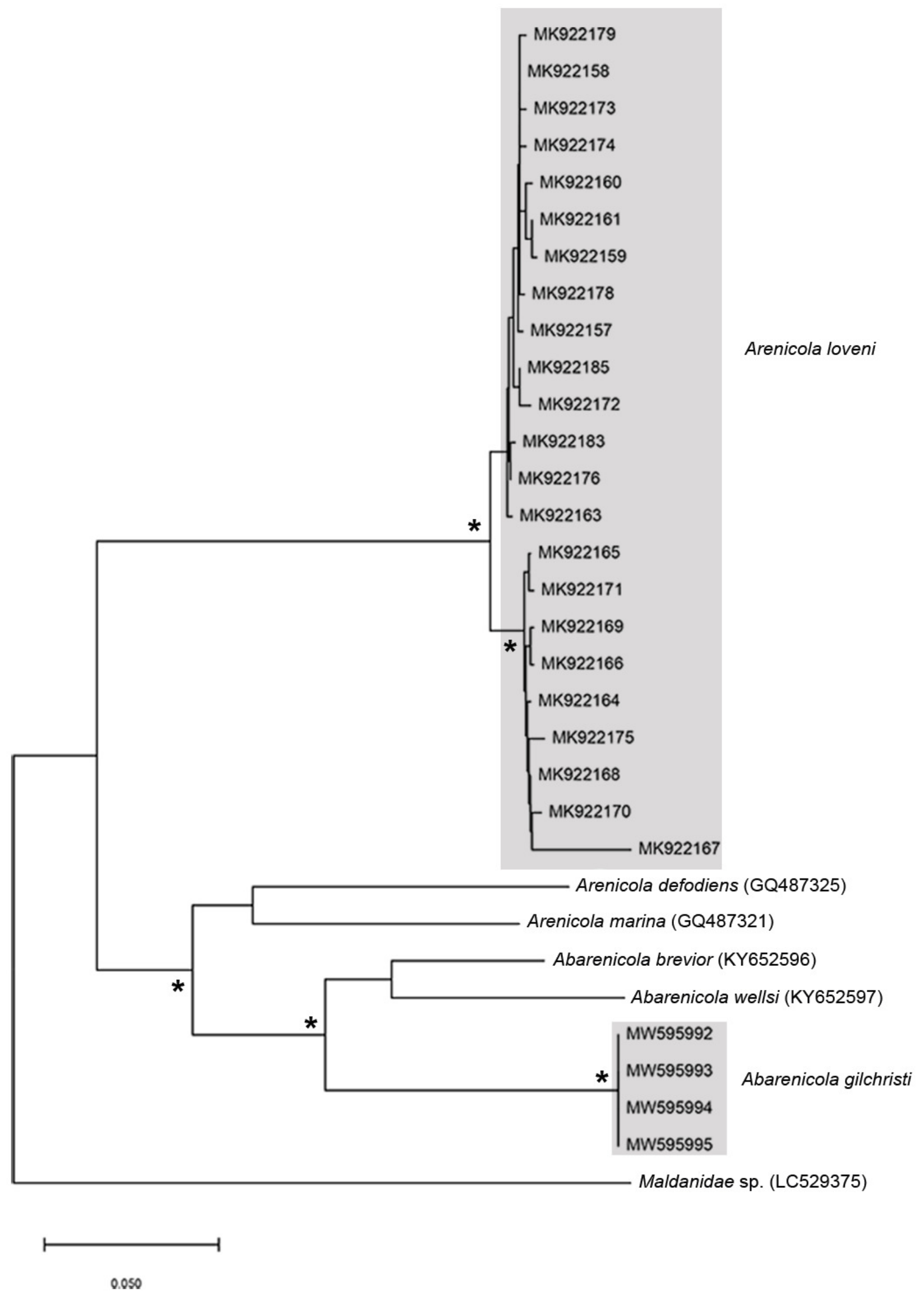




\section{Figure 8}

Morphology of Abarenicola gilchristi

Figure 8. Abarenicola gilchristi Wells, 1963 A) Live specimen, B) Dorso-lateral view of head, showing annulations on chaetigers 1 to 2 (arrowheads), C) Proboscis showing papillations in different regions, D) Dorsal view of head showing prostomium and partially everted proboscis, arrows show nuchal grooves, E) Digestive caecae; one large pair and multiple smaller pairs, F) Papillae of distal part of proboscis, G) Papillae of median part of proboscis, H) Papillae of proximal part of proboscis, I) Branchia on chaetiger 9, J) Unhooded nephridiopore, K) Hooded nephridiopore, L) Partially hooded nephridiopore. Scale bars: A = 2 $\mathrm{mm}, \mathrm{B}, \mathrm{C}, \mathrm{D}, \mathrm{E}=5 \mathrm{~mm} ; \mathrm{I}=2 \mathrm{~mm}, \mathrm{~F}-\mathrm{H}=2 \mathrm{~mm}$, J $\mathrm{L}=0.5 \mathrm{~mm} ; \mathrm{A}$, J: MB-A090223, B, I, K, L = MB-A090224; C - H = MB-A090226. 


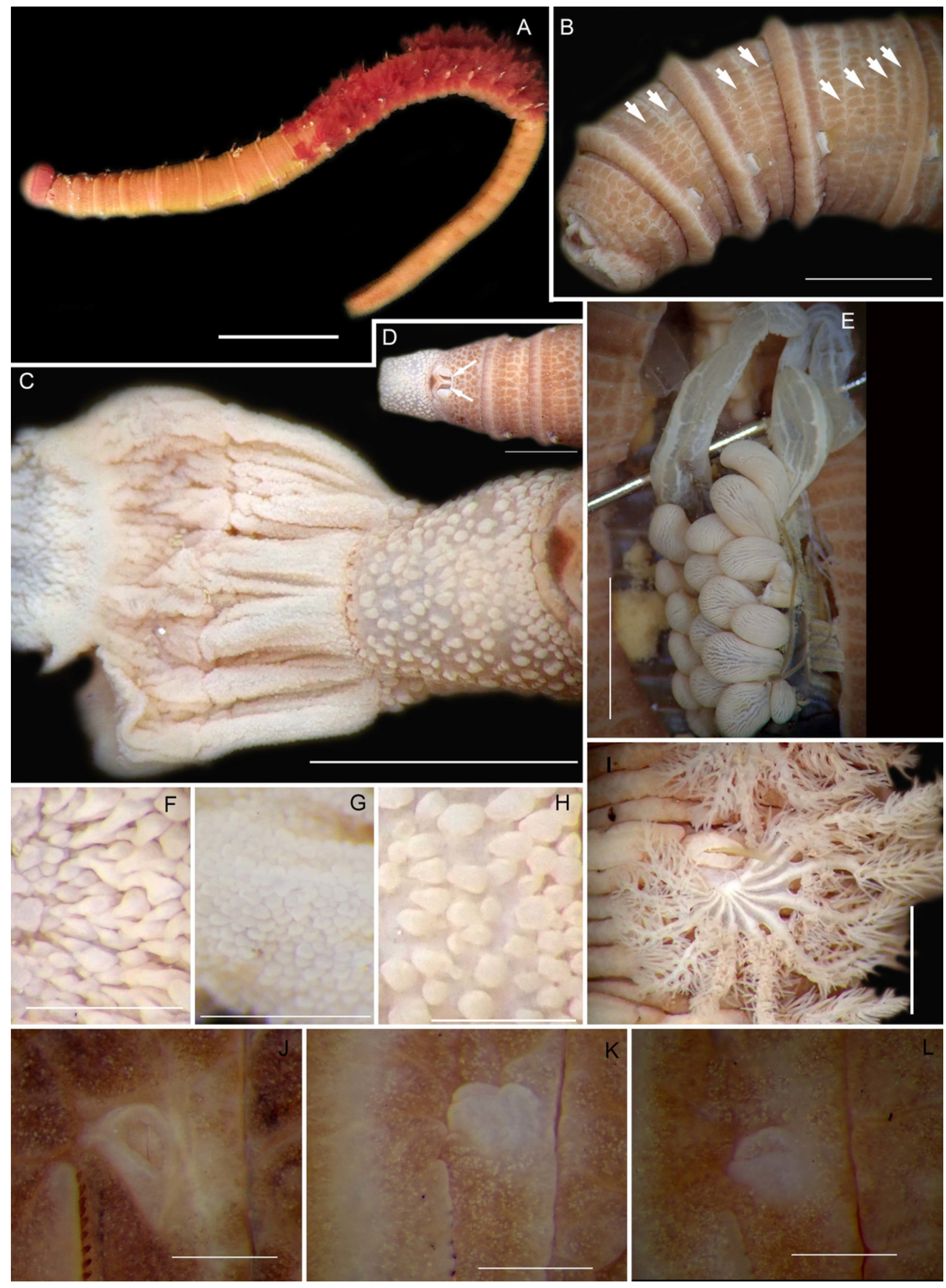




\section{Figure 9}

Morphology of Gunnarea gaimardi

Figure 9. Gunnarea gaimardi (Quatrefages, 1848). A) Live specimen from Betty's Bay, B) Dorsal view of crown showing the inner paleae (ip), outer paleae (op), opercular disk (od), papillae (cp), C) Right side view of crown showing the tentacular filaments (tf), D) Palee, 1 \&3: outer geniculate paleae with tooth, 2: inner geniculate paleae, E) Ventral view of anterior region showing palps (p), median ridge (mr), and U-shaped building organ (bo), F) Bipinnate capillaries, neurochaetae, G) Lanceolate chaetae of two lengths, neurochaetae, H) Lanceolate and capillaries, notochaetae, I) Verticillate chaetae, neurochaetae, J) Uncini. Scale bars: $A \& C=5 \mathrm{~mm}, B \& E=2 \mathrm{~mm}, D=0.5 \mathrm{~mm}, F, I, J=50 \mu \mathrm{m}, \mathrm{G} \& \mathrm{H}=0.2 \mathrm{~mm}$. B, F - J $=$ MB-A090337, $C=$ MB-A090343, $d=$ MB $=A 090371$. 

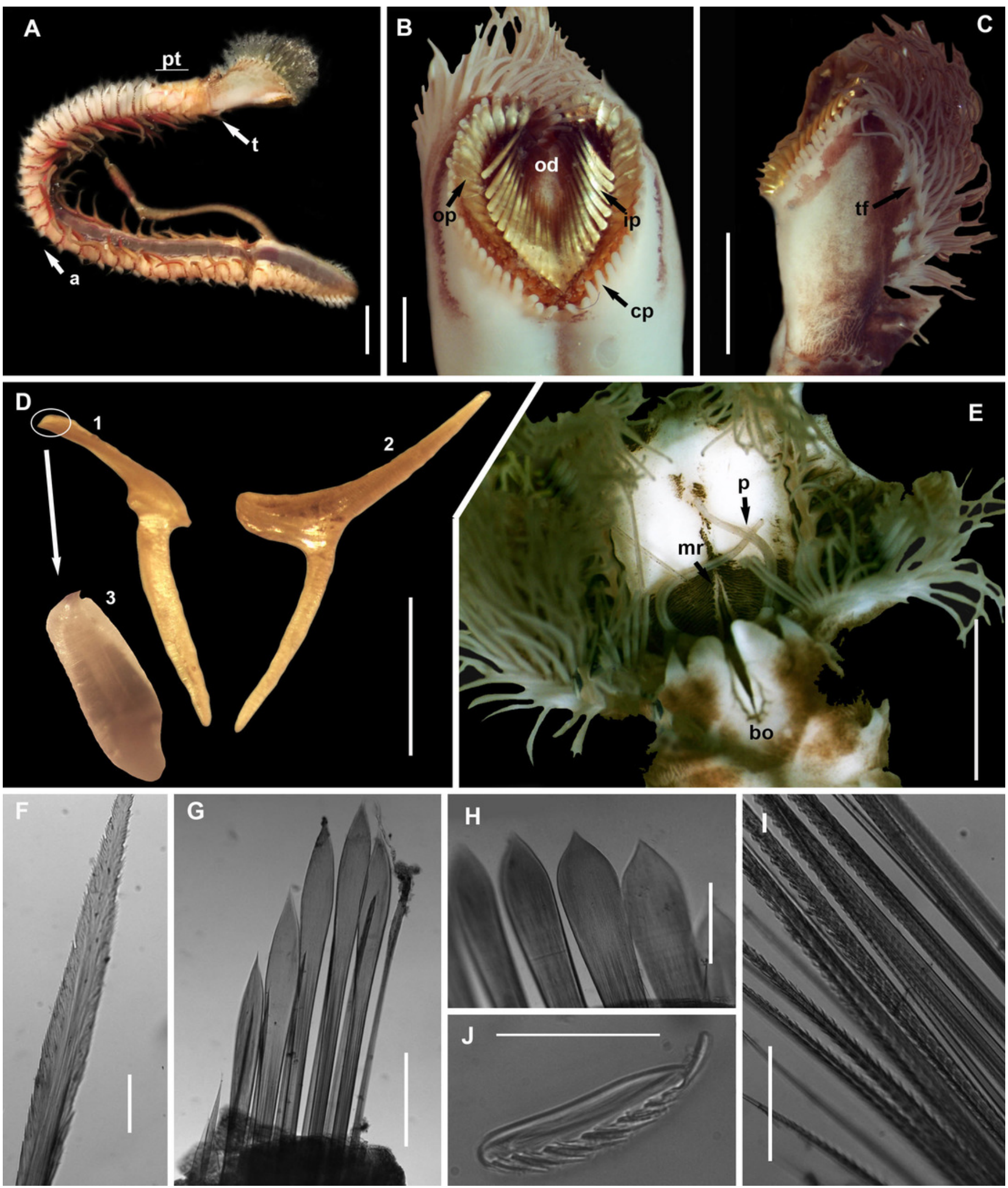


\section{Figure 10}

Neighbour joining tree of Gunnarea

Figure 11. Neighbour Joining tree of mitochondrial sequences of various species from family Sabellariidae Johnston, 1865 including Gunnarea capensis (Schmarda, 1861). * Indicates bootstrap support greater than $80 \%$. Areas in grey represent sequences generated in this study. Spirobranchus sinuspersicus Pazoki, Rahimian, Struck, Katouzian \& Kupriyanova, 2020 was used to root the tree. Scale bar represents substitutions per site. 


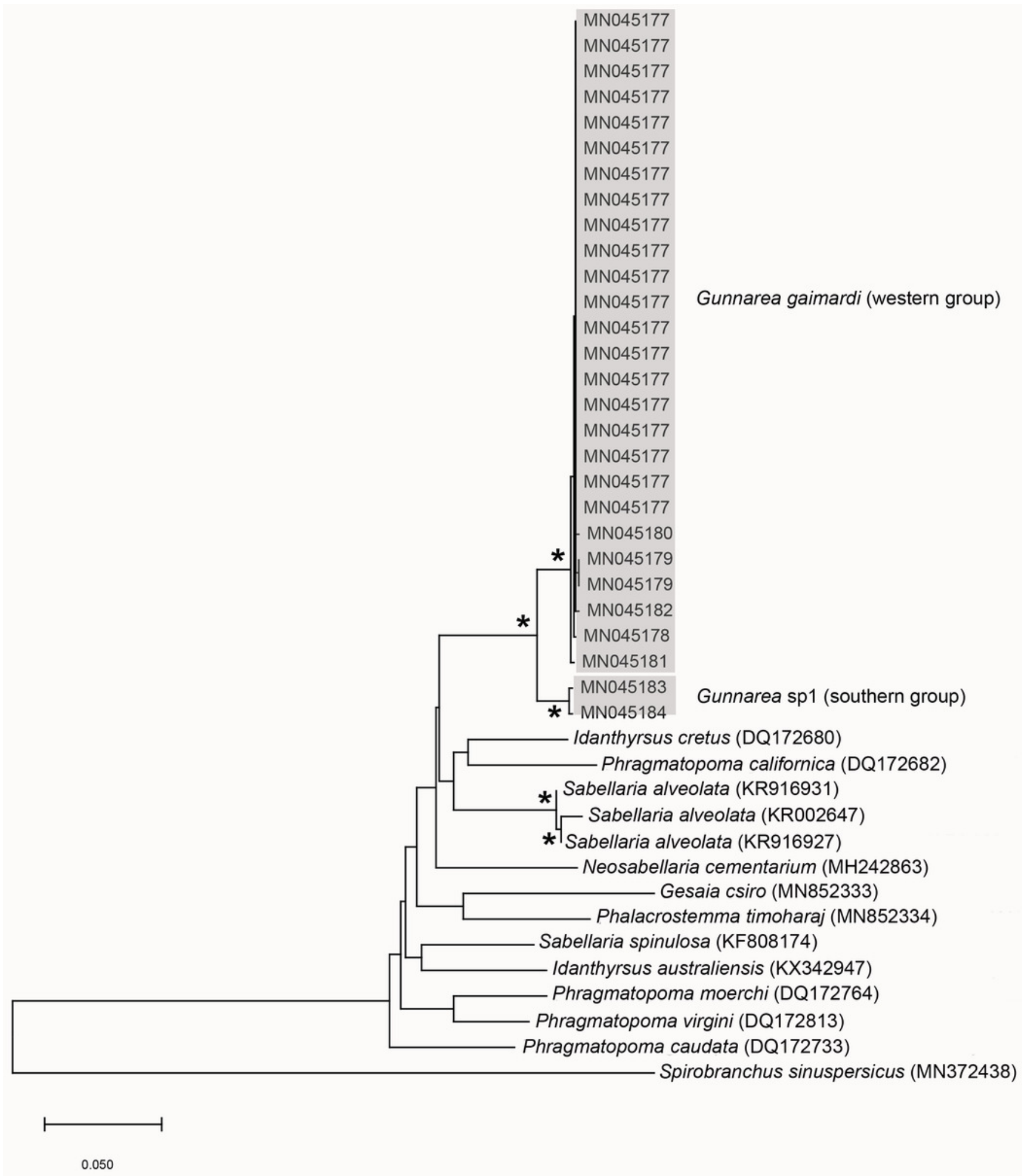




\section{Figure 11}

Morphology of Gunnarea species

Figure 10. Gunnarea Johannson, 1927 species collected from Witsand. A) Live specimen, B) Crown showing the inner paleae (ip) and outer paleae (op), C) Neurochaetae of first thoracic chaetiger, D) Abdominal neurochaetae, E) Anterior region showing palps ( $p$ ), Buccal lip (upper and lateral sides) and tentacular filaments (tf), F) Posterior uncinus, G) Palaea 1- inner geniculate paleae, $2 \& 3$ - outer geniculate paleae with tooth, H) Lanceolate notochaetae, I) Neurochaetae. Scale bars: $A=5 \mathrm{~mm}, B \& E=1 \mathrm{~mm}, C, D, F, G=0.5 \mathrm{~mm}, \mathrm{H}-\mathrm{I}=0.2 \mathrm{~mm} . \mathrm{A}, \mathrm{C}, \mathrm{F}$ $-I=$ MB-A090293, B, E = MB-A090294 

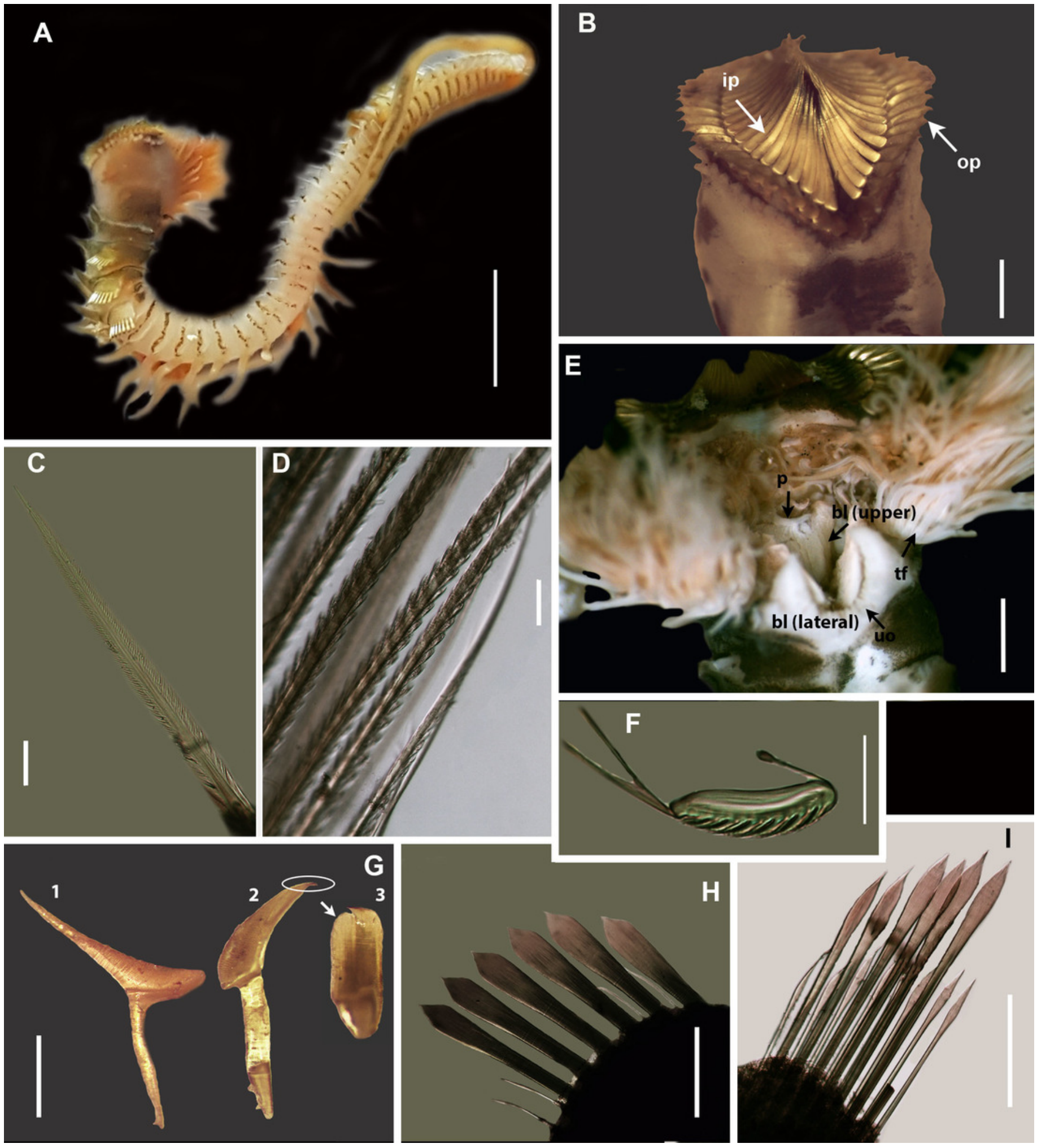


\section{Figure 12}

Morphology of Scoletoma species from Betty's Bay

Figure 12. Scoletoma species 1 from Betty's Bay. A) Dorsal anterior, B) MIII and MIV of jaws, ventral view, C) Chaetiger 5 showing pre-chaetal ( $\mathrm{PrCl}$ ) and post chaetal (PCl) lobes, anterior view, D) Chaetiger 31 showing prechaetal and post chaetal lobes, anterior view, E) Posterior chaetiger showing prechaetal and post chaetal lobes, anterior view, F) Long-headed multidentate hooded hooks on chaetiger 5, G) Long-headed multidentate hooded hook on chaetiger 31, H) Short-headed multidentate hook with flared hood from posterior chaetiger.

Scale bars: $A=5 \mathrm{~mm}, B-E=0.5 \mathrm{~mm}, \mathrm{~F}-\mathrm{H}=0.2 \mathrm{~mm}$. A - H $=$ MB-A090332 


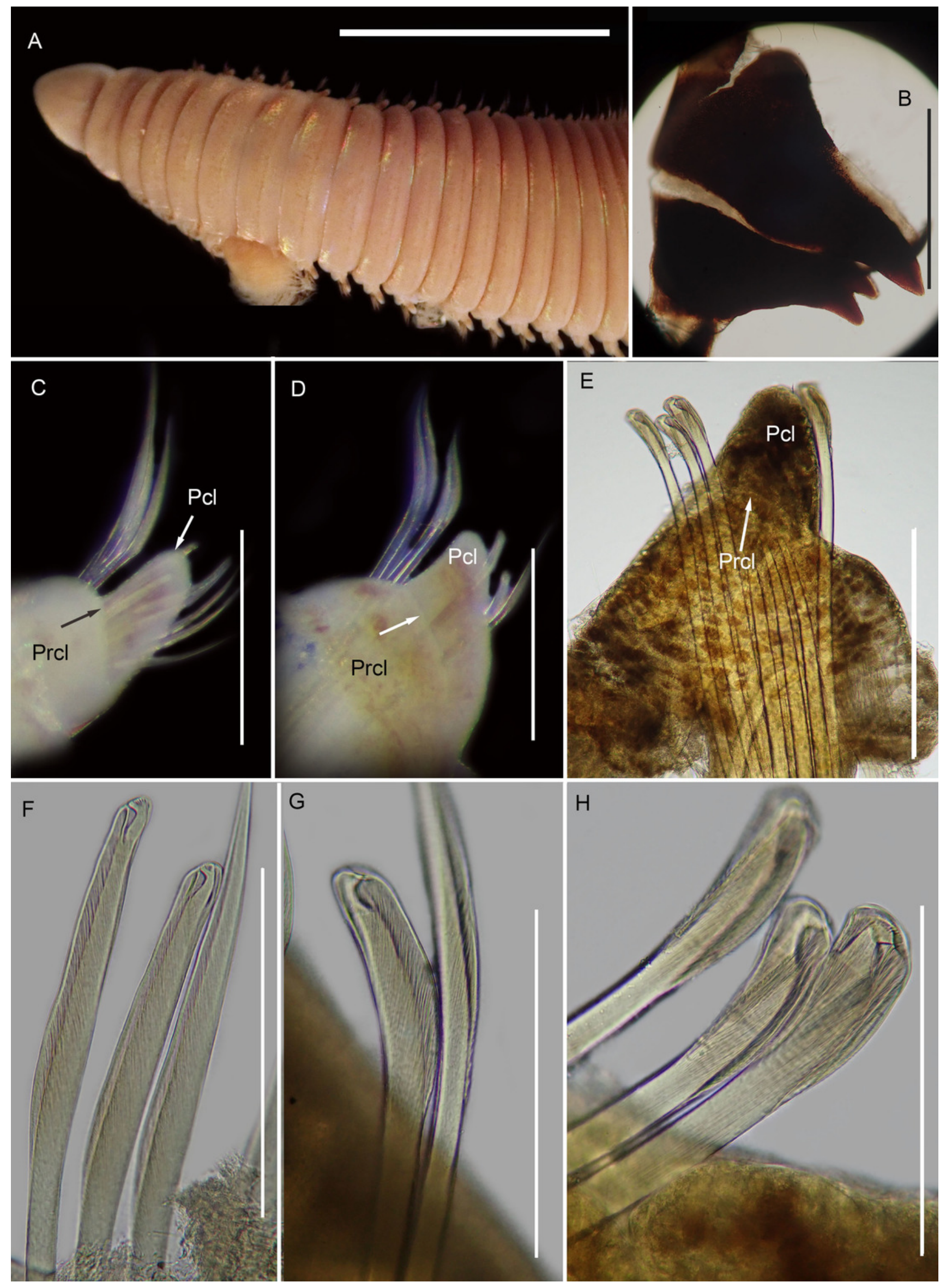




\section{Figure 13}

Neighbour joining tree of Lumbrineridae

Figure 14. Neighbour joining tree of mitochondrial sequences of various species in Lumbrineridae, including Scoletoma tetraura (Schmarda, 1861) from China. * Indicates bootstrap support greater than $80 \%$. Areas highlighted in grey represent sequences generated in this study; Scoletoma species sp. 1 and sp. 2. Area outlined with grey dashed line represents S. tetraura from China. Arabella iricolor (Montagu, 1804) and A. semimaculata (Moore, 1911) were used as outgroups. Scale bar indicates substitutions per site. 


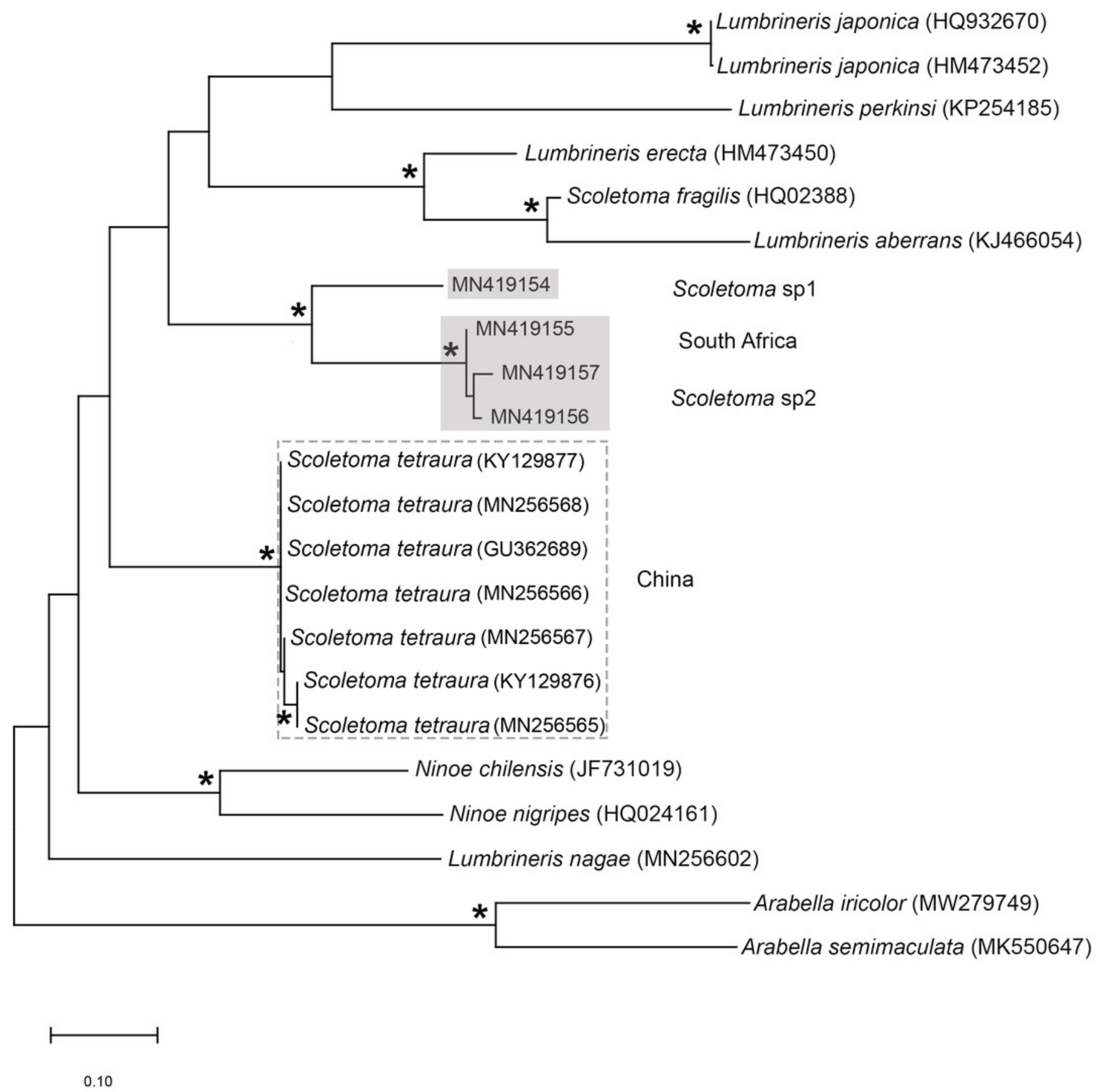




\section{Figure 14}

Morphology of Scoletoma species from Hermanus

Figure 13. Scoletoma species 2 from Hermanus. A) Dorsal anterior, B) MIII and MIV of jaws, ventral view, C) Chaetiger 3 showing pre-chaetal ( $\mathrm{PrCl}$ ) and post chaetal ( $\mathrm{PCl}$ ) lobes anterior view, D) Chaetiger 30 showing pre- and post chaetal lobes, anterior view, E) Posterior chaetiger showing pre- and post chaetal lobes, anterior view, F) Long-headed multidentate hooded hooks on chaetiger 5, G) Long-headed multidentate hooded hook on chaetiger 31, H) Short-headed multidentate hook with flared hood from posterior chaetiger. Scale bars: $\mathrm{A}=$ $5 \mathrm{~mm}, \mathrm{~B}-\mathrm{E}=0.5 \mathrm{~mm}, \mathrm{~F}-\mathrm{H}=0.2 \mathrm{~mm}$. A - H $=$ MB-A090353 


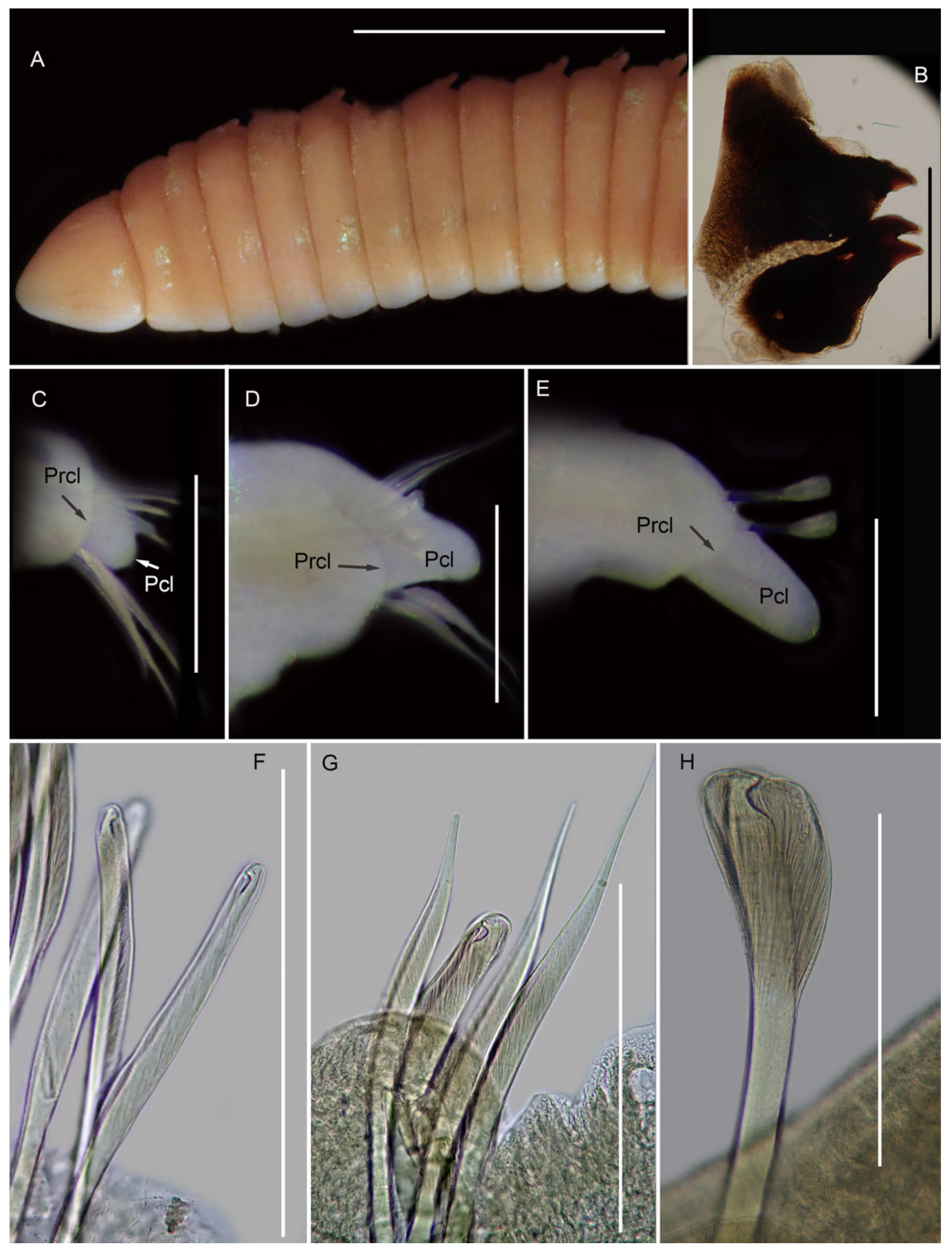




\section{Figure 15}

Morphology of Marphysa corallina

Figure 15. Marphysa cf corallina A) Anterior region (dorsal), live specimen, B) Posterior chaetiger with branchiae, C) Compound bidentate falcigers with guards , D) Limbate capillaries, E) Chaetae, acicula and subacicular hooks, F) Dorsal view of Maxillary apparatus

Scale bars: $A=5 \mathrm{~mm}, B=0.5 \mathrm{~mm}, C \& D=50 \mu \mathrm{m}, E=0.2 \mathrm{~mm}, F=2 \mathrm{~mm} . A, C \& D=M B-$ A090276, E \& F = MB-A090280. Figure 16. Neighbour Joining tree of various species belonging to family Eunicidae Berthold, 1827, including Marphysa Quatrefages, 1866 and Lysidice Lamarck, 1818 from South Africa. * Indicates bootstrap support greater than or equal to $80 \%$. Grey highlighted areas indicate sequences generated in this study. Red branch represents a questionable sequence labelled as Lysidice natalensis Kinberg, 1865 from India. Palola viridis Gray in Stail, 1847, Leodice rubra Grube, 1856 and Hyalinocea sp. were used as outgroups. Scale bar represented substitutions per site. 

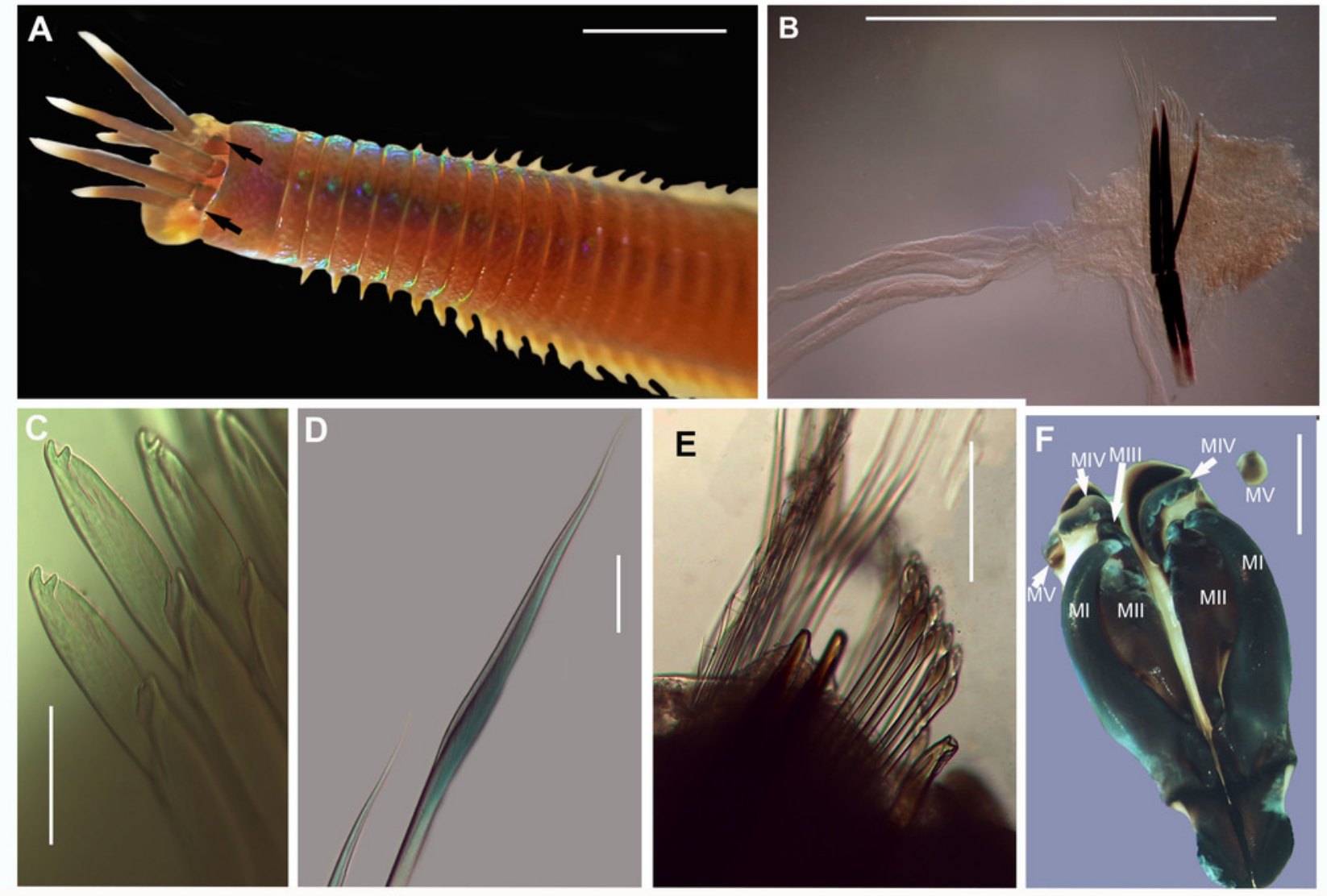


\section{Figure 16}

Neighbour Joining tree of Eunicidae

Figure 16. Neighbour Joining tree of various species belonging to family Eunicidae, including Marphya and Lysidice from South Africa. * Indicates bootstrap support greater than $80 \%$.

Grey highlighted areas indicate sequences generated in this study. Red branch represents a questionable sequence labelled as Lysidice natalensis from India. Palola viridis, Eunice rubra and Hyalinocea sp. were used as outgroups. Scale bar represented substitutions per site. 


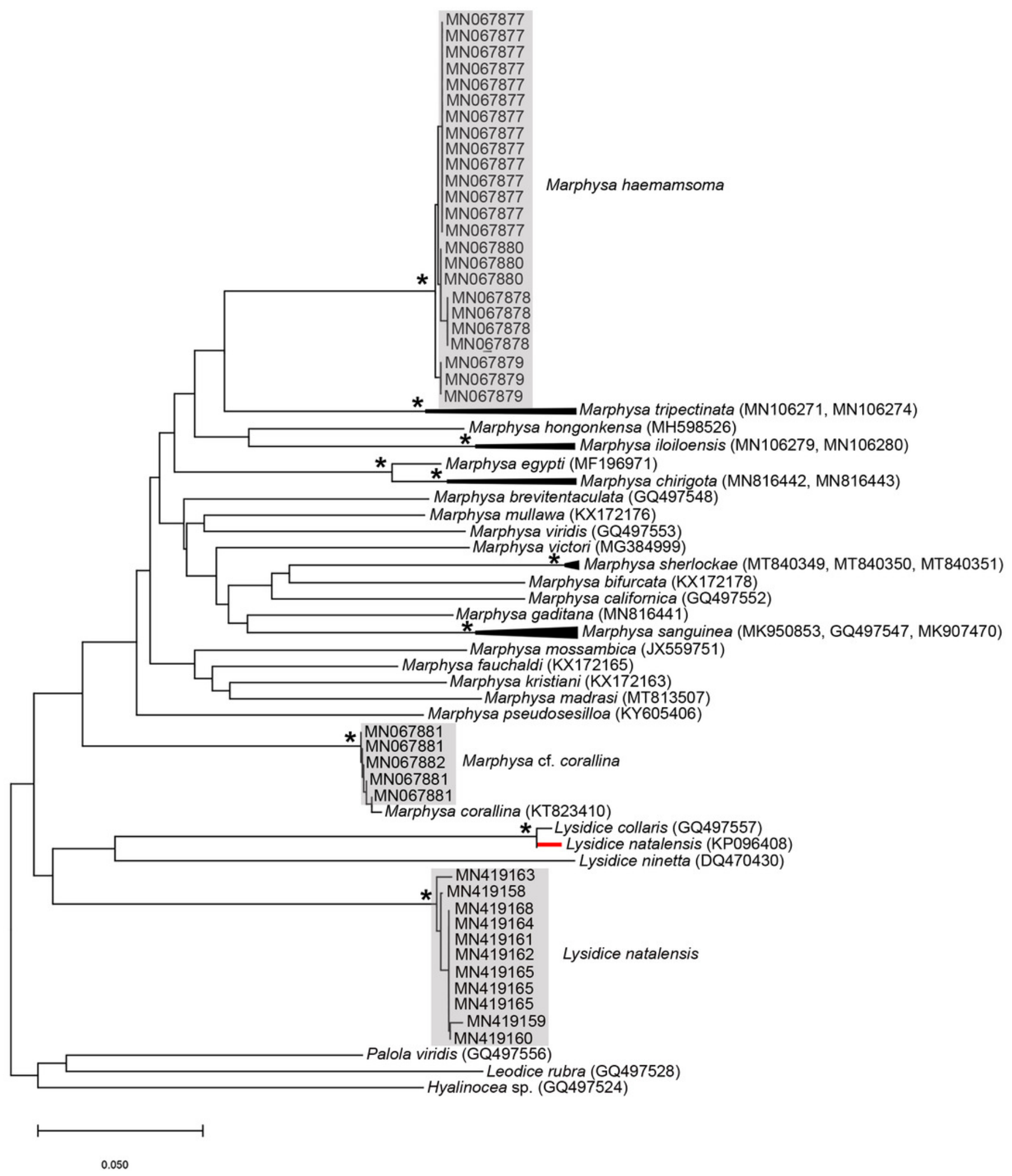




\section{Figure 17}

Morphology of Marphysa haemasoma

Figure 17. Marphysa haemasoma Quatrefages, 1866. A) Dorsal anterior, live specimen B)

Dorsal anterior of live specimen, arrow showing blue colouration C) Dorsal view of maxillary apparatus, D) Pectinate anodont chaetae E) Middle chaetiger with branchia, F) Pectinate isodont chaetae, G) Pectinate anodont chaetae. Scale bars: $A \& B=5 \mathrm{~mm}, C=2 \mathrm{~mm}, D, F \& G$ $=50 \mu \mathrm{m}, \mathrm{E}=0.25 \mathrm{~mm} . \mathrm{A}=\mathrm{MB}-\mathrm{A} 090326, \mathrm{~B}=\mathrm{MB}-\mathrm{A} 090328, \mathrm{C}=\mathrm{MB}-\mathrm{A} 090274, \mathrm{D}, \mathrm{F}-\mathrm{G}=\mathrm{MB}-$ A090273.
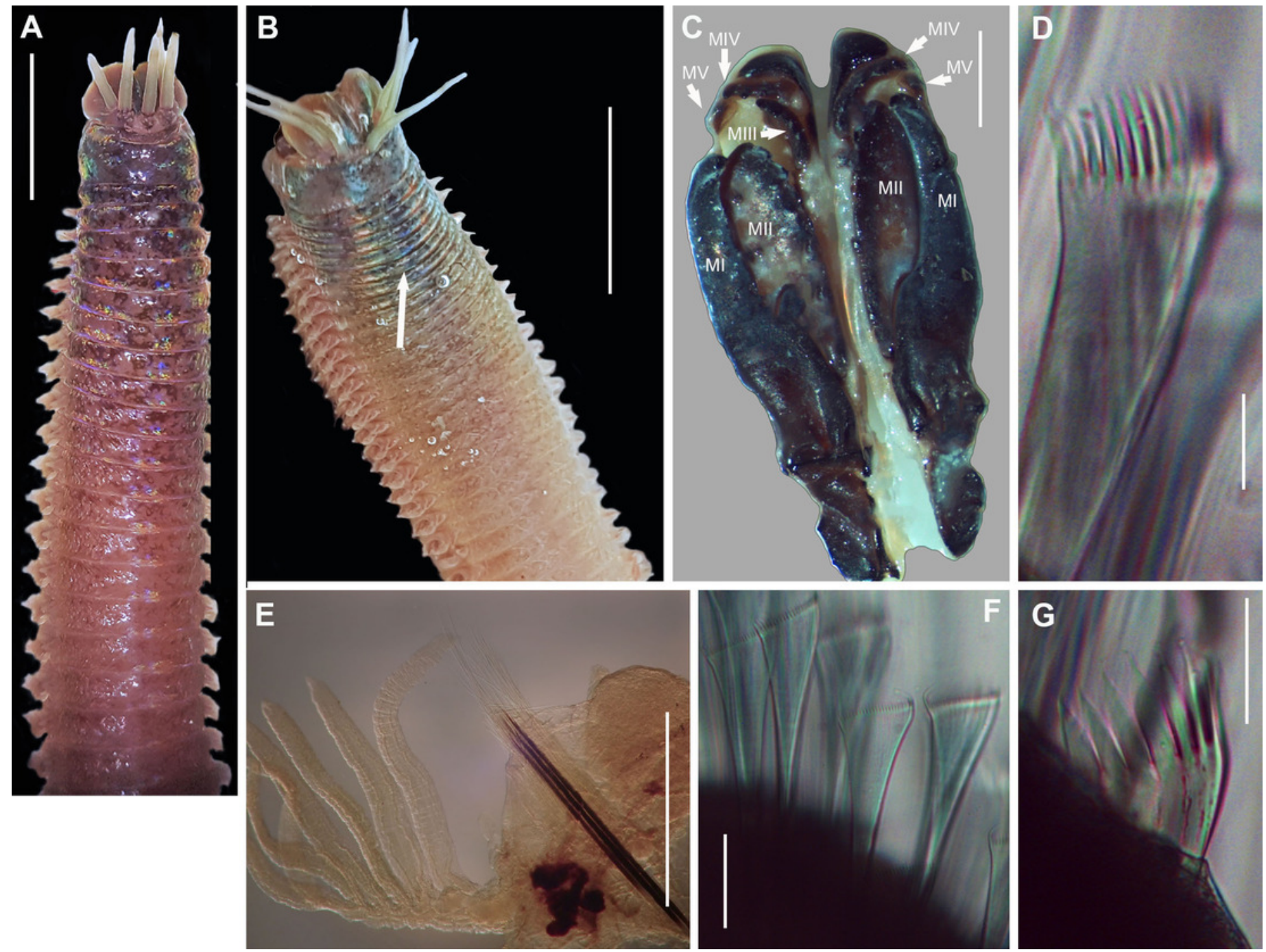


\section{Figure 18}

Morphology of Lysidice natalensis.

Figure 18. Lysidice natalensis Kinberg, 1865. A) Dorsal of head, live specimen, B) Chaetiger

5, anterior view, C) Compound falciger of chaetiger 5, D) Compound falciger of chaetiger 28,

E) Chaetiger 28, anterior view F) Limbate and comb (white arrowheads) chaetae of chaetiger

28, G) Acicula hook of chaetiger 28, H) Posterior chaetiger. Scale bars: $A=1 \mathrm{~mm}, \mathrm{~B}, \mathrm{E}, \mathrm{H}=$ $0.5 \mathrm{~mm}, \mathrm{C}, \mathrm{D}, \mathrm{F}, \mathrm{G}=0.05 \mathrm{~mm}$. A - H = MB-A090291. 

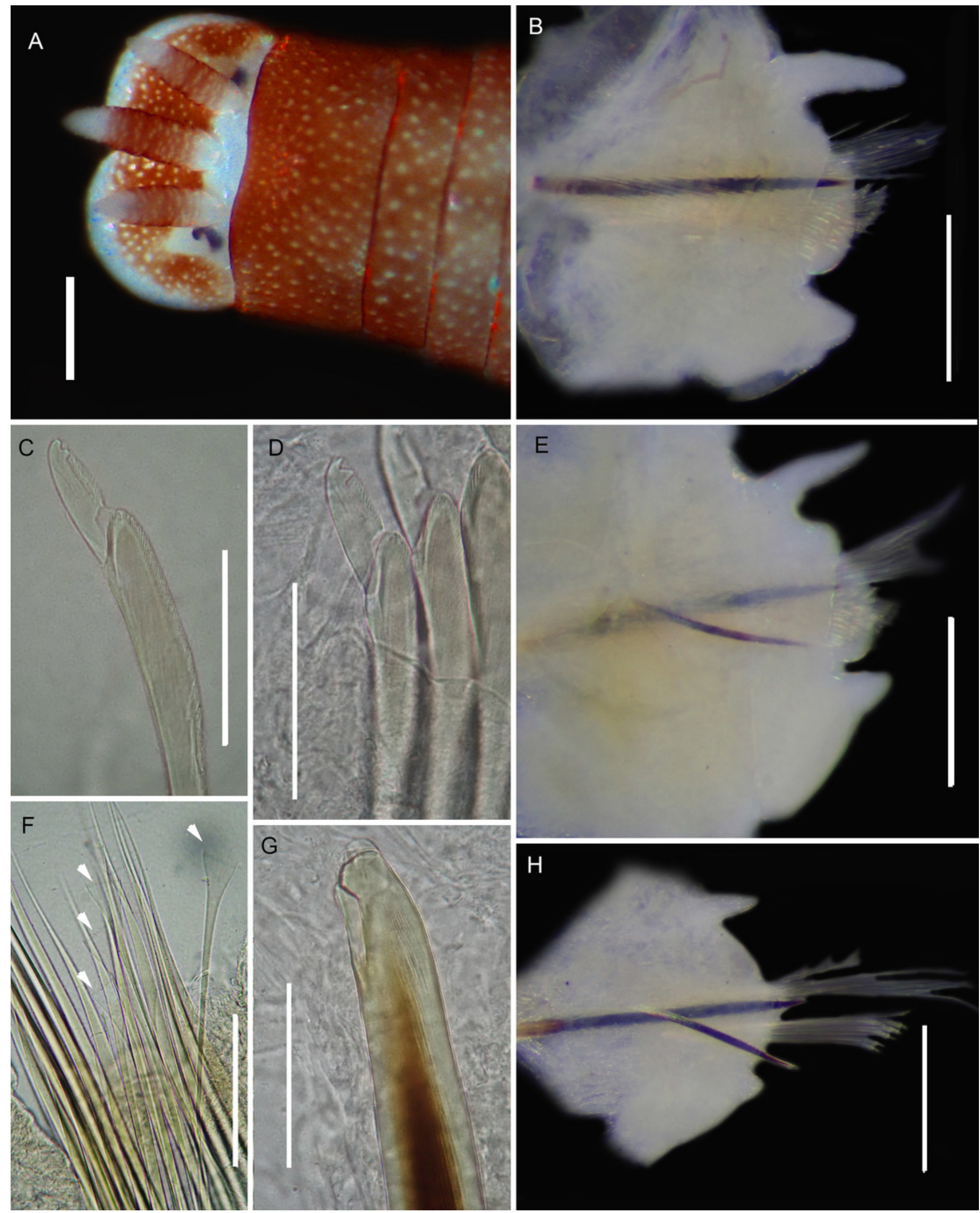


\section{Figure 19}

Morphology of Heptaceras quinquedens

Figure 19. Heptaceras quinquedens (Day, 1951). A) Dorsal anterior of preserved specimen showing peristomial notch flanking prostomial ridge, laterally curving peristomial cirri and iridescent shine that remains after preservation, B) Dorsal anterior of live specimen, insert shows freckled spots on anterior dorsum, C) Ventral anterior of preserved specimen, D) Lateral anterior view of preserved specimen showing cylindrical shape of modified parapodia and progression of ventral cirri from subulate to globular form, E) Dorsal view of live specimen from chaetiger 11 - 92 showing fading of colouration from anterior to middle of body, F) Lateral view of live mid-section, G) Bidentate and tridentate falcigers, with minor third tooth encircled, H) Dorsal cirri from chaetiger 82 with small basal process encircled, I) Bidentate acicular chaetae, J) Pectinate chaetae. $\mathrm{DC}=$ Dorsal cirri, $\mathrm{BR}=$ Branchiae, VCS $=$ Ventral cirri subulate form, VCG = Ventral cirri globular form, C5 = Chaetiger five. Scale bars: $A=1 \mathrm{~mm} ; B, C, D, F=5 \mathrm{~mm} ; E=10 \mathrm{~mm} ; G, I=0.1 \mathrm{~mm} ; J=5 \mu \mathrm{m} . \mathrm{A}, \mathrm{D}, \mathrm{H}=\mathrm{MB}-\mathrm{A} 090434 ; B, E$, $F=M B-A 090442 ; C, G, J=M B-A 090424$. 


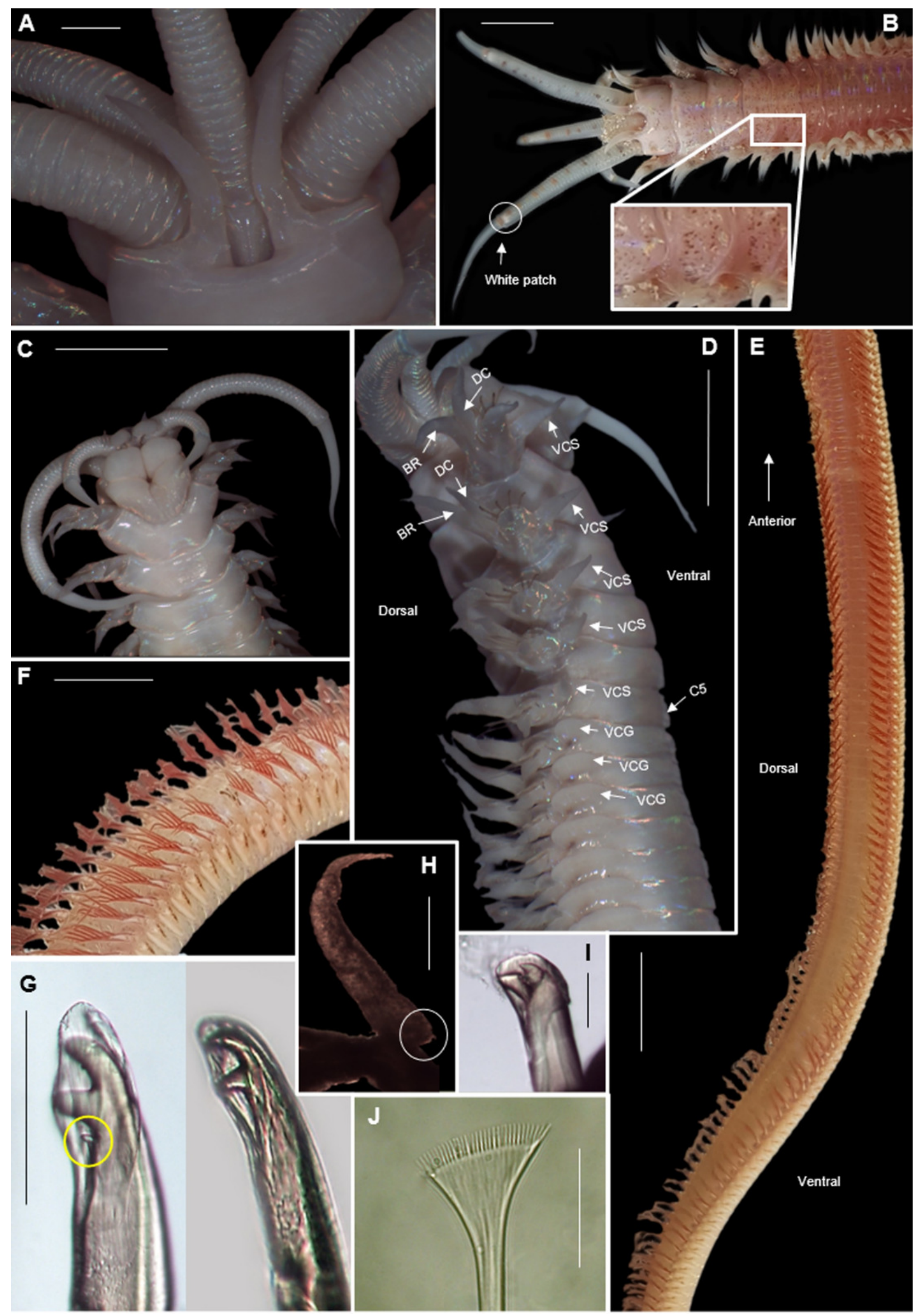

Peer) reviewing PDF | (2021:04:59876:2:0:NEW 28 Jun 2021) 


\section{Figure 20}

Morphology of Platynereis latipalpa

Figure 20. Perineseis latipalpa (Schmarda, 1861). A) Anterior region (dorsal), B) Middle region showing red colouration on segments (dorsal), C) Everted pharynx showing Areas 1, 2, 3, 4 (antero-ventral), D) Everted pharynx showing Areas V and VI (dorsal), E) Everted pharynx showing Areas VII-VIII (ventro-lateral), F) Heterogomph spinigers (heS) and homogomph spinigers (hoS) with enlarged teeth at base, $G$ ) Heterogomph falcigers with finely serrated blade. Scale bars: $A \& B, D=5 \mathrm{~mm}, C \& E=2 \mathrm{~mm}, F-G=0.1 \mathrm{~mm}$. 


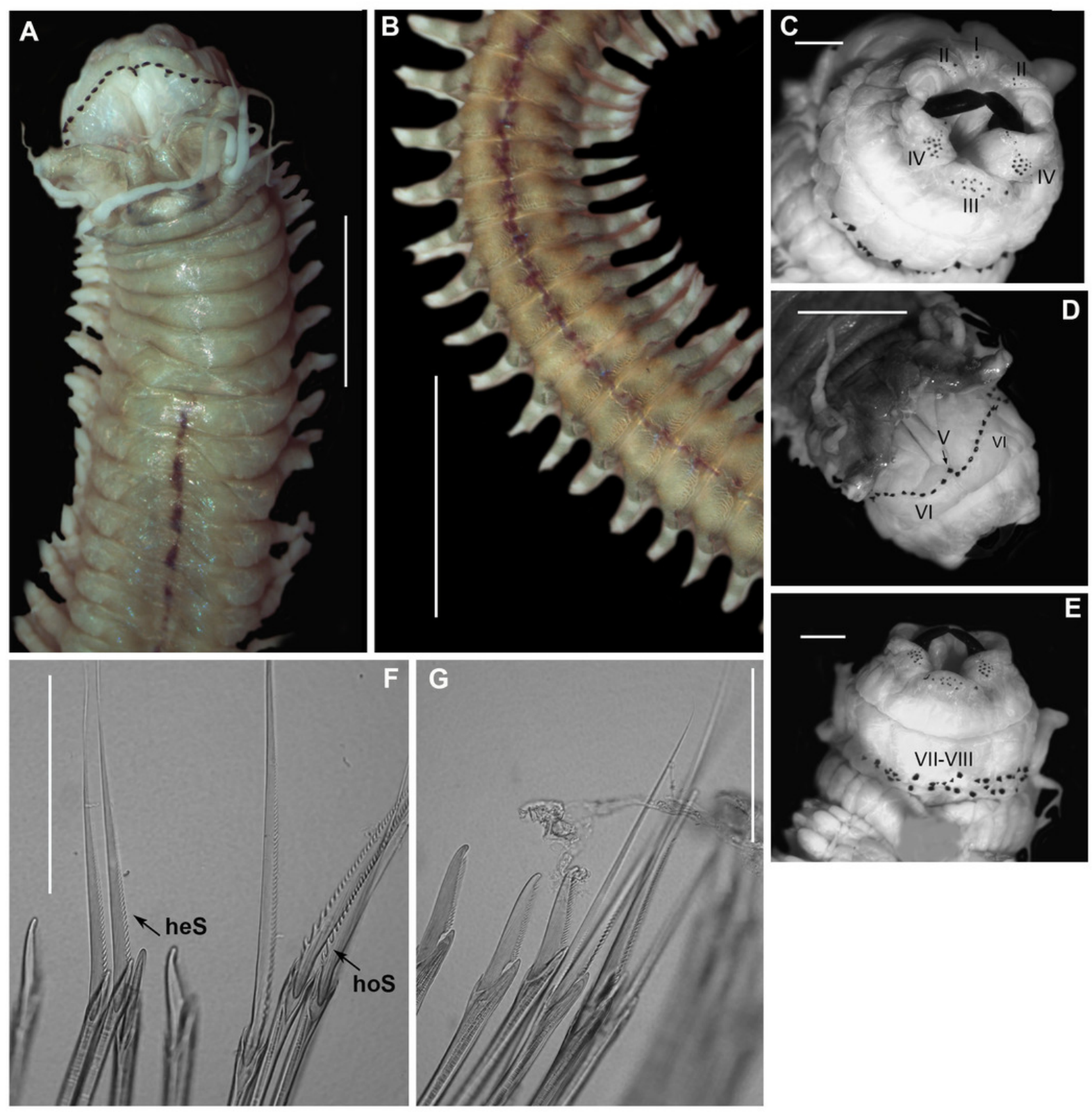




\section{Figure 21}

Morphology of Pseudonereis podocirra

Figure 21. Pseudonereis podocirra (Schmarda, 1861). A) Anterior region (dorsal), B) Posterior region, (dorsal), C) Paragnaths on pharynx, Areas I - VIII, D) Compound falciger with serrated blade, E) Compound spiniger with serrated blade, F) 30th chaetiger (dorsal). Scale bars: A - C $=2 \mathrm{~mm}, \mathrm{D} \& \mathrm{E}=0.1 \mathrm{~mm}, \mathrm{~F}=1 \mathrm{~mm}$. 

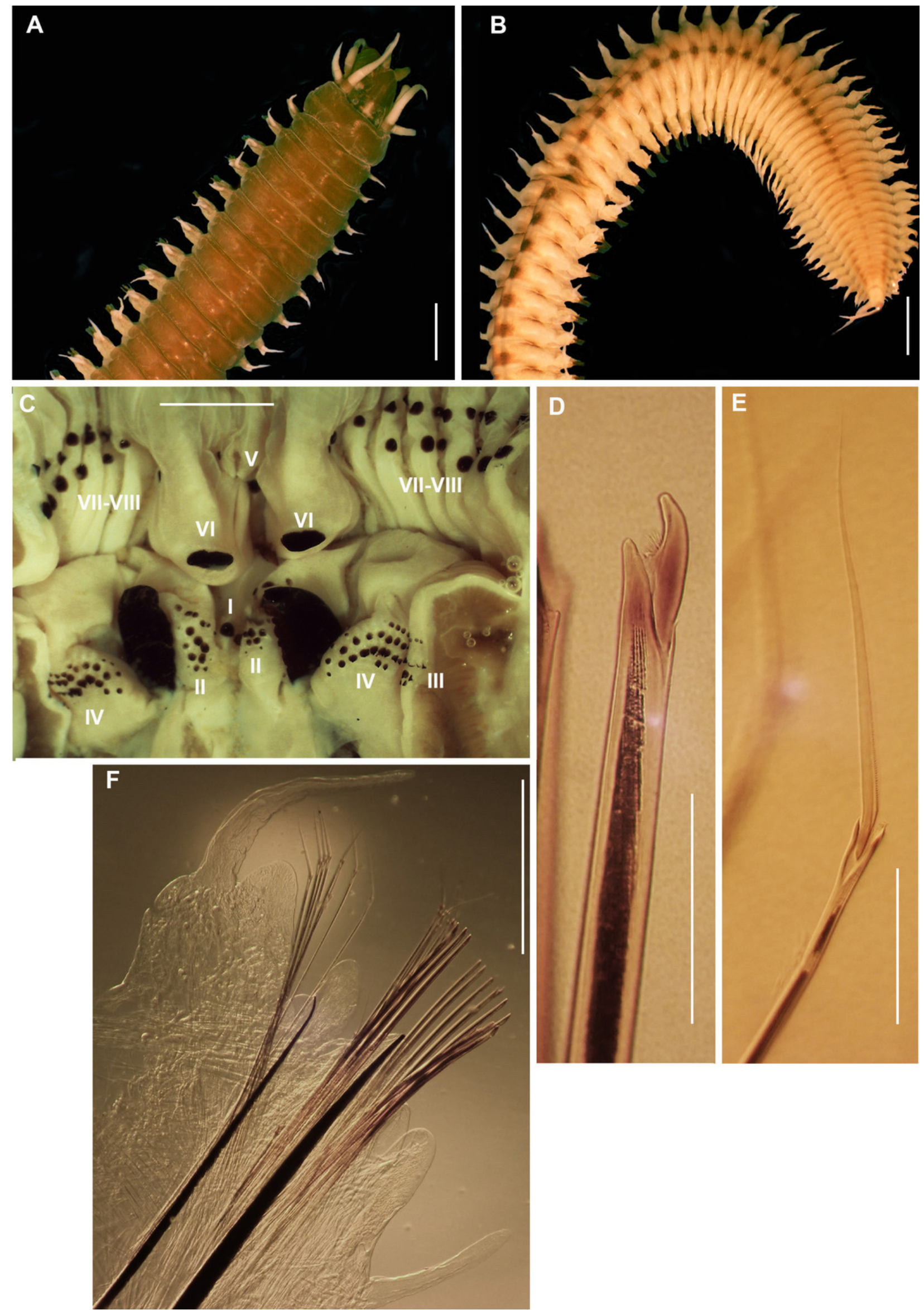

Peer) reviewing PDF | (2021:04:59876:2:0:NEW 28 Jun 2021) 


\section{Figure 22}

Neigbour joining tree of Pseudonereis

Figure 22. Neighbour Joining tree of various species belonging to Pseudonereis Kinberg, 1865b. * Indicates bootstrap support greater than or equal to $80 \%$. Area highlighted in grey indicates sequences generated in the present study. Perinereis aibuhitensis (Grube, 1878) was used as an outgroup. Scale bar represents substitutions per site.

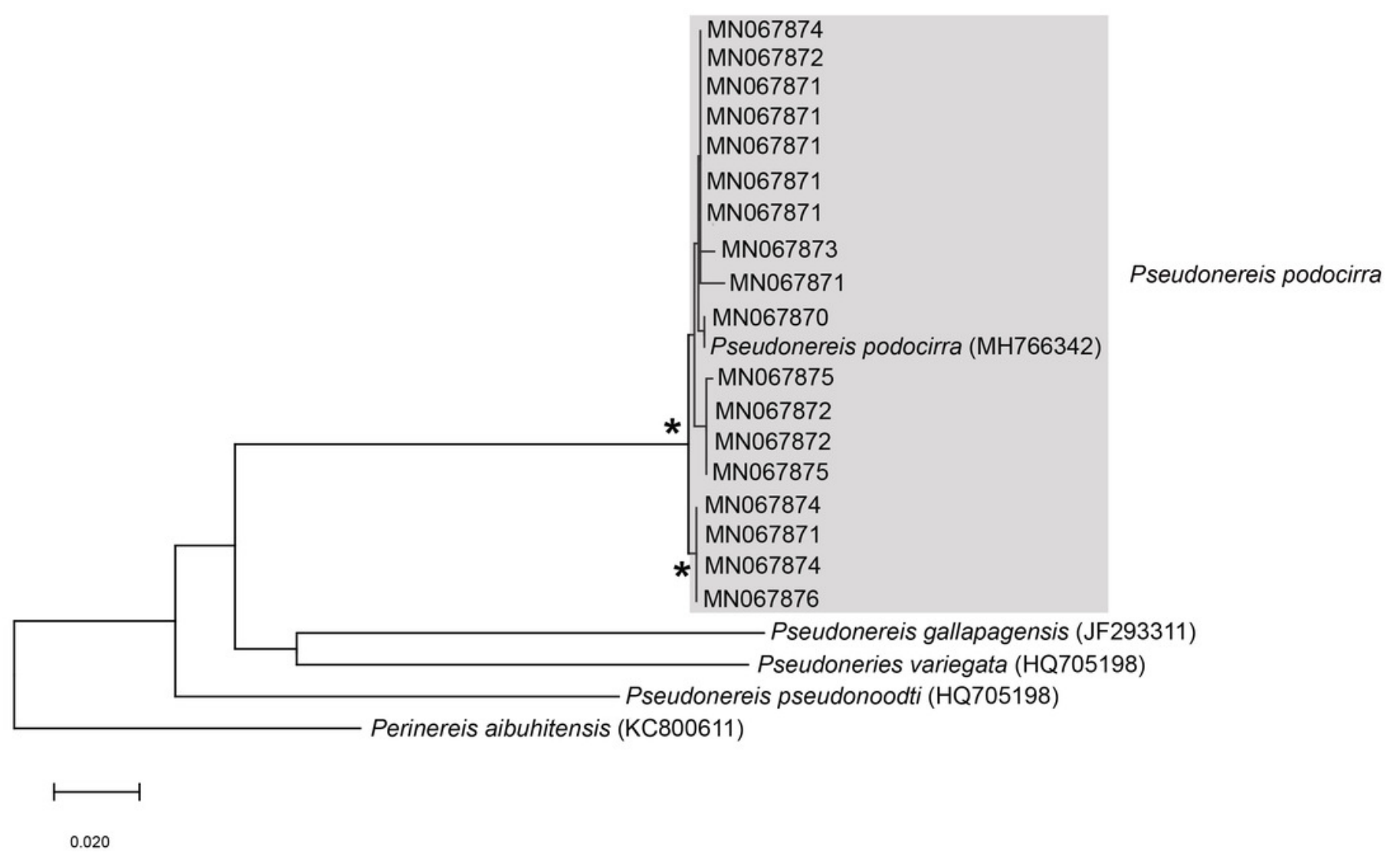

